\section{Pacific Northwest} National Laboratory

Operated by Battelle for the

U.S. Department of Energy

\title{
Results of Detailed Hydrologic Characterization Tests - Fiscal Year 2002
}

\author{
F. A. Spane, Jr. \\ D. R. Newcomer \\ P. D. Thorne
}

February 2003

Prepared for the U.S. Department of Energy under Contract DE-AC06-76RL01830 


\title{
DISCLAIMER
}

This report was prepared as an account of work sponsored by an agency of the United States Government. Reference herein to any specific commercial product, process, or service by trade name, trademark, manufacturer, or otherwise does not necessarily constitute or imply its endorsement, recommendation, or favoring by the United States Government or any agency thereof, or Battelle Memorial Institute.

\author{
PACIFIC NORTHWEST NATIONAL LABORATORY \\ operated by \\ BATTELLE \\ for the \\ UNITED STATES DEPARTMENT OF ENERGY \\ under Contract DE-AC06-76RL01830
}

Printed in the United States of America

Available to DOE and DOE contractors from the

Office of Scientific and Technical Information, P.O. Box 62, Oak Ridge, TN 37831;

prices available from (615) 576-8401.

\begin{abstract}
Available to the public from the National Technical Information Service,
U.S. Department of Commerce, 5285 Port Royal Rd., Springfield, VA 22161
\end{abstract}

This document was printed on recycled paper. 


\title{
Results of Detailed Hydrologic Characterization Tests - Fiscal Year 2002
}

\author{
F. A. Spane, Jr. \\ D. R. Newcomer \\ P. D. Thorne
}

February 2003

Prepared for

the U.S. Department of Energy

under Contract DE-AC06-76RL01830

Pacific Northwest National Laboratory

Richland, Washington 99352 


\begin{abstract}
This report provides the results of detailed hydrologic characterization tests conducted within newly constructed Hanford Site wells during fiscal year 2002. Detailed characterization tests performed included groundwater-flow characterization, barometric response evaluation, slug tests, single-well tracer tests, constant-rate pumping tests, and in-well vertical flow assessments. Hydraulic property estimates obtained from the detailed hydrologic tests include hydraulic conductivity, transmissivity, specific yield, effective porosity, in-well lateral flow velocity, aquifer-flow velocity, vertical distribution of hydraulic conductivity (within the well-screen section), and in-well vertical flow velocity. In addition, local groundwater-flow characteristics (i.e., hydraulic gradient and flow direction) were determined for two sites where detailed well testing was performed. Results obtained from these tests provide hydrologic information that supports the needs of RCRA waste management area characterization and sitewide groundwater monitoring and modeling programs and reduces the uncertainty of groundwater-flow conditions at selected locations on the Hanford Site.
\end{abstract}




\section{Summary}

The U.S. Department of Energy's Hanford Groundwater Monitoring Project, managed by Pacific Northwest National Laboratory, examines the potential for offsite migration of contamination within aquifer systems underlying the Hanford Site. An important characterization element that helps define the migration of contamination is the analysis of hydrologic tests, which provide estimates of hydraulic properties for the tested aquifer systems. Information gained from the analysis of hydrologic tests is important when evaluating aquifer-flow characteristics (i.e., groundwater-flow velocity) and transport travel time, which are key parts of effective groundwater monitoring and modeling. Obtaining representative information about the hydraulic properties of the unconfined aquifer beneath the Hanford Site can be complicated by temporal changes in the water-table elevation and associated aquifer thickness. In particular, earlier hydrologic tests in the 200-West and 200-East Areas may reflect overlying, hydrogeologic units that are no longer saturated and are not part of the current groundwater flow system. Obtaining current information on hydraulic properties of the aquifer provides a way to assess the reliability of earlier data and provides up-to-date information that can be used for effective groundwater monitoring and modeling.

This report presents test results obtained from the detailed hydrologic characterization program of the unconfined aquifer system conducted for the Hanford Groundwater Monitoring Project during fiscal year (FY) 2002. Hydrologic tests conducted as part of the detailed program include the following:

- slug testing (6 wells tested)

- tracer-dilution tests (2 wells tested)

- tracer-pumpback tests (2 wells tested)

- constant-rate pumping tests (2 wells tested)

- vertical flow, in-well assessment (1 well tested)

Hydrologic test results conducted during FY 2002 reflect hydrogeologic Unit 5 of the Ringold Formation (gravel Unit E) for wells tested in the 200-West Area, and reflective of reworked Ringold Formation Unit 5 for the well tested in the 200-East Area. Hydraulic property estimates obtained from the detailed hydrologic tests include hydraulic conductivity, transmissivity, specific yield, effective porosity, in-well lateral groundwater-flow velocity, aquifer groundwater-flow velocity, vertical distribution of hydraulic conductivity, and in-well vertical flow velocity. In addition, local groundwaterflow characteristics (i.e., hydraulic gradient, flow direction) were determined for the two sites where detailed well testing was performed. Pertinent results from the FY 2002 detailed characterization program are summarized in the following paragraphs.

Slug-test results provided hydraulic conductivity estimates that ranged between 0.39 and $27.9 \mathrm{~m} /$ day for the five 200 -West Area wells, and $89 \mathrm{~m} /$ day for the one 200-East Area well. These results are consistent with previously reported slug-test values for the Ringold Formation within the 200-West Area and slightly higher than previously reported values for the 200-East Area. The hydraulic conductivity 
estimates derived from slug tests correspond closely with values obtained from constant-rate pumping tests and fall within the error range commonly reported for slug tests in aquifer characterization studies (i.e., within a factor of $\sim 2$ or less).

Constant-rate pumping-test results for transmissivity ranged between 91 and $121 \mathrm{~m}^{2} /$ day (average $106 \mathrm{~m}^{2} /$ day). These values fall within the lower range recently reported by Spane et al. (2001a, 2001b, 2002) for constant-rate pumping tests conducted during FY 1999 through 2001 (range $=44$ to $1130 \mathrm{~m}^{2} /$ day; average $=334 \mathrm{~m}^{2} /$ day) within the 200 -West Area. The two FY 2002 pumping test-derived values are also lower than the large-scale transmissivity values of 300 and $327 \mathrm{~m}^{2}$ /day that were reported in Newcomb and Strand (1953) and Wurstner et al. (1995), respectively, for the unconfined aquifer within the 200-West Area. The FY 2002 results are also lower than the large-scale analysis of induced effects of the 200-ZP-1 pump-and-treat system reported in Spane and Thorne (2000), which produced large-scale estimates that range between 230 and $430 \mathrm{~m}^{2}$ /day (average $325 \mathrm{~m}^{2} /$ day).

Results of pumping tests also correspond fairly closely for specific yield, ranging between 0.09 and 0.12 , and fall within the range previously reported in Spane et al. (2001a, 2001b, 2002) for pumping tests within this area. These results also compare favorably with previously reported estimates of 0.11 and 0.17 for the 200-West Area (i.e., Newcomb and Strand 1953; Wurstner et al. 1995). These earlier estimates were based on analyzing the growth and decline of the groundwater mound beneath the 200-West Area associated with wastewater-disposal practices in the area.

Results of tracer-dilution tests indicate that well 299-W14-14 exhibited in-well vertical downward flow conditions within the lower well-screen section ( 0.0054 to $0.0058 \mathrm{~m} /$ minute). The existence of in-well vertical flow conditions may compromise the results of the tracer test conducted at this well location. Average, in-well lateral flow velocities, $\mathrm{v}_{\mathrm{w}}$, for well sections and sites not exhibiting in-well vertical flow ranged between 0.041 to $0.090 \mathrm{~m} /$ day. These estimates are within the range of 0.007 and $0.170 \mathrm{~m} /$ day cited in Spane et al. $(2001 \mathrm{a}, 2001 \mathrm{~b}, 2002)$ for other single-well tracer tests in these areas.

A comparison of the observed depth versus velocity profiles from tracer-dilution tests provided information about permeability distribution within the well-screen sections at the two well sites. At well 299-W14-14, very uniform low, in-well lateral flow velocities were exhibited for the upper three sensor depth locations (range: 0.037 to $0.040 \mathrm{~m} /$ day). This suggests that formation permeabilities do not vary by more than $10 \%$ within the upper $\sim 5$ meter section of the well screen. No inference on permeability distribution could be made for the lower well-screen section due to the exhibited in-well vertical flow conditions. For well 299-W22-84 slightly more variable in-well lateral flow velocities were exhibited (range: 0.076 to $0.094 \mathrm{~m} /$ day), suggesting that permeabilities do not vary by more than $20 \%$ within the entire well-screen section; with the lowest relative permeabilities (i.e., lower flow velocities) occurring within the upper section of the well-screen. 
Estimates for effective porosity for the two test sites (wells 299-W14-14 and 299-W22-84) were identical at 0.020 . This value falls slightly below the range commonly reported for semi-consolidated to unconsolidated alluvial aquifers $(0.05$ to 0.30$)$ and is slightly below the lower range previously reported by Spane et al. (2001a, 2001b, 2002) of 0.027 to 0.272 for single-well tracer tests conducted in the 200West Area.

Estimates for aquifer groundwater-flow velocity also were nearly identical and ranged between 0.121 and $0.122 \mathrm{~m} /$ day and generally fall within a factor of 3 of the calculated, in-well flow velocities. A similar relationship between groundwater-flow velocity estimates and calculated in-well flow velocities was reported in Spane et al. (2001a, 2001b, 2002) for single-well tracer tests conducted during FY 1999 through FY 2001.

Groundwater-flow characterization results for the two detailed hydrologic characterization sites, based on trend-surface analysis of surrounding well water-level elevations, provided hydraulic gradients that range between 0.00112 and 0.00183 for these selected locations within the 200 -West Area. The trend-surface analysis results also indicated groundwater flows predominantly in an east and southeast direction. The hydraulic gradient and calculations of flow direction are consistent with previous generalizations for the 200-West Area, as presented in Spane et al. (2001a, 2001b, 2002) and Hartman et al. (2002). 


\section{Acknowledgments}

Several Pacific Northwest National Laboratory staff contributed to the hydrologic tests presented in this report. In particular, Kirk Cantrell provided laboratory and field support for the tracer tests. Tyler Gilmore participated in the performance and data acquisition of some of the field tests. Alex Mitroshkov performed laboratory bromide analyses on discrete water samples collected during tracer-pumpback tests. Bruce Williams provided identification of hydrogeologic units tested at the well sites. The field-testing personnel and test equipment support provided by Duratek Federal Services, Inc. is also acknowledged.

In addition, Pacific Northwest National Laboratory staff contributed significantly to this report's preparation. Tyler Gilmore and Stuart Luttrell provided technical peer review comments. Thanks also are extended to Signe Wurstner for hydrologic testing software support. In addition, L. C. Swanson of Fluor Hanford, Inc., D. J. Meyer of CH2M-HILL Hanford, and M. J. Furman of the U.S. Department of Energy, Richland Operations Office, also provided technical peer review comments. 


\title{
Nomenclature
}

\author{
$\mathrm{A}=$ cross-sectional area within well screen; $\mathrm{L}^{2}$ \\ $\mathrm{b}=$ aquifer thickness; $\mathrm{L}$ \\ $\mathrm{C}=$ tracer concentration in the test interval at time, $\mathrm{t} ; \mathrm{M}$ per $\mathrm{L}^{3}$ \\ $\mathrm{C}_{\mathrm{D}}=$ slug test well response damping parameter; dimensionless \\ $\mathrm{C}_{\mathrm{o}}=$ initial tracer concentration in well at the start of the test; $\mathrm{M}$ per $\mathrm{L}^{3}$ \\ $\mathrm{C}_{\mathrm{t}}=$ average tracer concentration in well at test termination; $\mathrm{M}$ per $\mathrm{L}^{3}$ \\ $\Delta \mathrm{h}_{\mathrm{w}}=$ water-level change over the last hour; $\mathrm{L}$ \\ $\Delta \mathrm{h}_{\mathrm{ai}}=$ barometric pressure change over the last hour; $\mathrm{L}$ \\ $\Delta \mathrm{h}_{\mathrm{a} \text { - }-1}=$ barometric pressure change from $2 \mathrm{~h}$ to $1 \mathrm{~h}$ previous; $\mathrm{L}$ \\ $\Delta \mathrm{h}_{\text {ai-n }}=$ barometric pressure change from $\mathrm{n}$ hours to (n-1) hour previous; $\mathrm{L}$ \\ $\mathrm{H}_{\mathrm{o}}=$ theoretical slug test stress level; L \\ $\mathrm{H}_{\mathrm{p}}=$ projected or observed slug test stress level; L \\ $\mathrm{H}_{\mathrm{p}-\mathrm{out}}=$ projected initial slug test stress level for outer zone analysis; $\mathrm{L}$ \\ $\mathrm{I}=$ hydraulic gradient; dimensionless \\ $\mathrm{K}=$ hydraulic conductivity; $\mathrm{L} / \mathrm{T}$ \\ $\mathrm{K}_{\mathrm{D}}=$ vertical anisotropy $\left(\mathrm{K}_{\mathrm{v}} / \mathrm{K}_{\mathrm{h}}\right)$; dimensionless \\ $\mathrm{K}_{\mathrm{h}}=$ hydraulic conductivity in the horizontal direction; $\mathrm{L} / \mathrm{T}$ \\ $\mathrm{K}_{\mathrm{hx}} / \mathrm{K}_{\mathrm{hy}}=$ horizontal anisotropy; dimensionless \\ $\mathrm{K}_{\text {snd }}=$ hydraulic conductivity of sandpack; L/T \\ $\mathrm{K}_{\mathrm{v}}=$ hydraulic conductivity in the vertical direction; $\mathrm{L} / \mathrm{T}$ \\ $\mathrm{m}=$ saturated thickness of test interval within well-screen section; $\mathrm{L}$ \\ $\mathrm{M}_{\mathrm{i}}=$ initial tracer mass emplaced in well; $\mathrm{M}$ \\ $\mathrm{M}_{\mathrm{r}}=$ tracer mass recovered during pumpback; $\mathrm{M}$ \\ $\mathrm{M}_{\mathrm{w}}=$ tracer mass in well and sandpack at time of pumpback; $\mathrm{M}$ \\ $\mathrm{M}_{50 \%}=50 \%$ of the tracer mass within the aquifer; $\mathrm{M}$ \\ $\mathrm{n}=$ number of hours that lagged barometric effects are apparent; dimensionless \\ $\mathrm{n}_{\mathrm{e}}=$ effective porosity; dimensionless \\ $\mathrm{Q}=$ pumping rate; $\mathrm{L}^{3} / \mathrm{T}$ \\ $\mathrm{Q}_{\text {avg }}=$ average pumping rate; $\mathrm{L}^{3} / \mathrm{T}$ \\ $\mathrm{Q}_{\mathrm{w}}=$ in-well lateral groundwater discharge within the well test interval; $\mathrm{L}^{3} / \mathrm{T}$ \\ $r_{c}=$ well casing radius; $\mathrm{L}$ \\ $\mathrm{r}_{\mathrm{eq}}=$ equivalent well casing radius; $\mathrm{L}$ \\ $\mathrm{r}_{\mathrm{eq} \text {-in }}=$ equivalent well casing radius for inner zone analysis; $\mathrm{L}$ \\ $\mathrm{r}_{\text {eq-out }}=$ equivalent well casing radius for outer zone analysis; $\mathrm{L}$ \\ $\mathrm{r}_{\mathrm{obs}}=$ radial distance from pumped well to monitor well location; $\mathrm{L}$ \\ $\mathrm{r}_{\mathrm{snd}}=$ sandpack radius; $\mathrm{L}$ \\ $\mathrm{r}_{\mathrm{t}}=$ equivalent radius of tracer measurement system; $\mathrm{L}$ \\ $\mathrm{r}_{\mathrm{w}}=$ radius of pumping well; $\mathrm{L}$ \\ $\mathrm{s}=$ drawdown; $\mathrm{L}$ \\ $\mathrm{S}=$ storativity; dimensionless \\ $\mathrm{S}_{\mathrm{s}}=$ specific storage; $1 / \mathrm{L}$
}


$\mathrm{S}_{\mathrm{y}}=$ specific yield; dimensionless

$\mathrm{T}=$ transmissivity; $\mathrm{L}^{2} / \mathrm{T}$

$\mathrm{t}=$ time; $\mathrm{T}$

$t_{d}=$ tracer dilution or drift time; $T$

$t_{p}=$ pumping time required to recover $50 \%$ of the tracer; $T$

$t_{t}=$ total elapsed tracer time, equal to $t_{d}+t_{p} ; T$

$\mathrm{V}=$ well volume over measurement section; $\mathrm{L}^{3}$

$\mathrm{V}_{\mathrm{w}}=$ test interval well volume; $\mathrm{L}^{3}$

$\mathrm{v}_{\mathrm{a}}=$ groundwater-flow velocity within aquifer; $\mathrm{L} / \mathrm{T}$

$\mathrm{v}_{\mathrm{v}}=$ vertical groundwater-flow velocity within well; $\mathrm{L} / \mathrm{T}$

$\mathrm{v}_{\mathrm{w}}=$ lateral groundwater-flow velocity within well; $\mathrm{L} / \mathrm{T}$

$\mathrm{V}_{\mathrm{wz}}=$ lateral groundwater-flow velocity for individual depths within well; $\mathrm{L} / \mathrm{T}$

$\mathrm{X}_{0} \ldots \mathrm{X}_{\mathrm{n}}=$ regression coefficients corresponding to time lags of 0 to $\mathrm{n}$ hours; dimensionless

$\mathrm{Y}_{\mathrm{o}}=$ slug test stress level; $\mathrm{L}$

$\sigma=$ dimensionless unconfined aquifer parameter, equal to $\mathrm{S} / \mathrm{S}_{\mathrm{y}}$

$\propto=$ groundwater-flow distortion factor; dimensionless, common range 0.5 to 4 


\section{Contents}

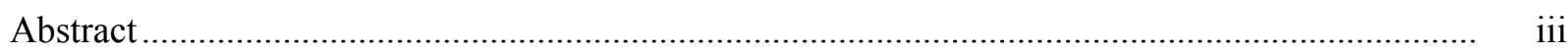

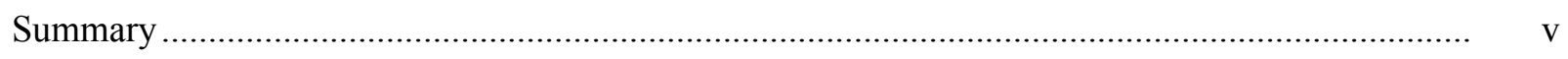

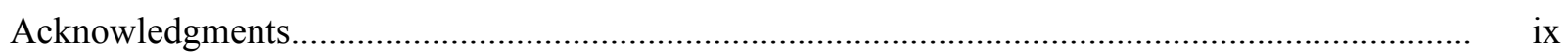

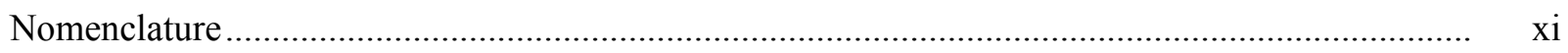

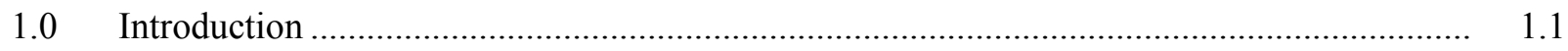

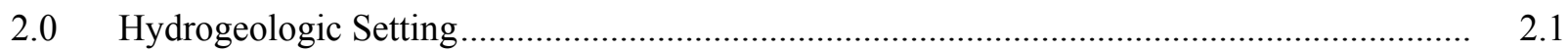

2.1 Hydrogeology of the 200-West Area ......................................................................... 2.1

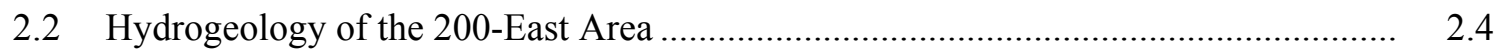

3.0 Detailed Test Characterization Methods ….................................................................... 3.1

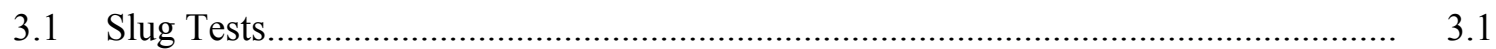

3.1.1 Bouwer and Rice Method...................................................................... 3.2

3.1.2 Type-Curve Method ............................................................................. $\quad 3.4$

3.1.3 Heterogeneous Formation Analysis .......................................................... 3.5

3.1.4 High Permeability Formation Analysis ...................................................... 3.9

3.2 Single-Well Tracer Tests ..................................................................... 3.9

3.2.1 Tracer-Dilution Tests ................................................................... 3.9

3.2.2 Tracer-Pumpback Tests ........................................................................ 3.11

3.2.3 In-Well Vertical Flow Assessment ....................................................... $\quad 3.13$

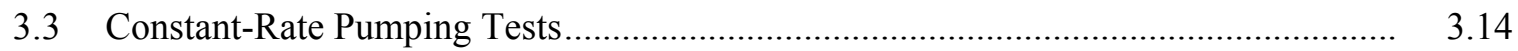

3.3.1 Test Methods and Equipment................................................................... 3.15

3.3.2 Barometric Pressure Effects Removal........................................................ $\quad 3.15$

3.3.3 Diagnostic Analysis and Derivative Plots .................................................... 3.16

3.3.4 Type-Curve-Matching Analysis Methods ............................................... 3.18

3.3.5 Straight-Line Analysis Methods................................................................. 3.19

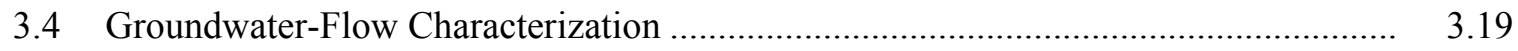

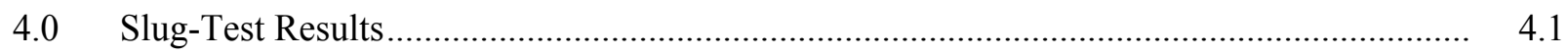

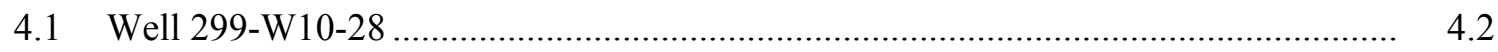

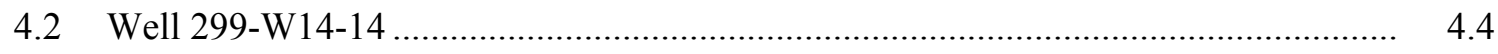

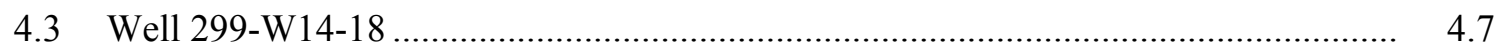




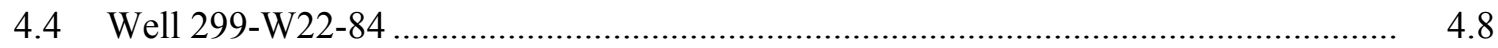

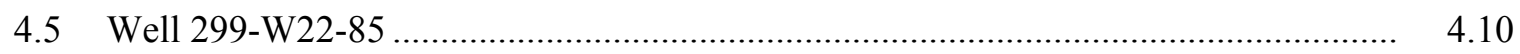

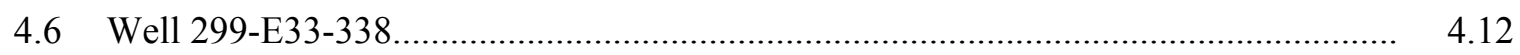

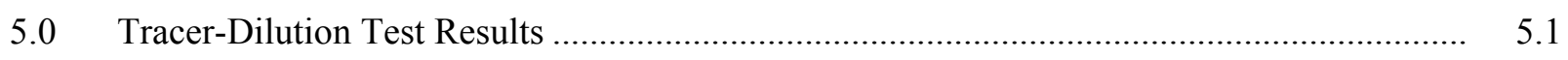

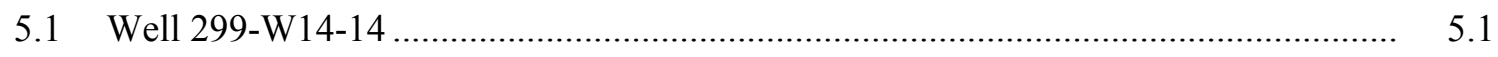

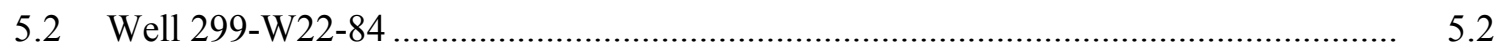

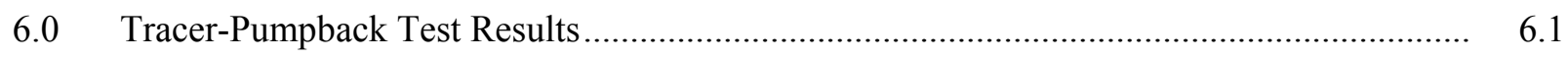

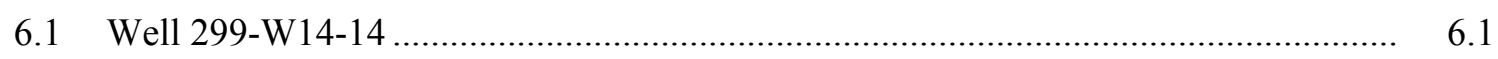

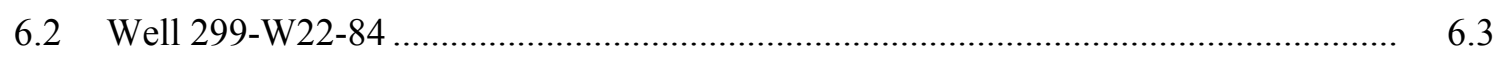

7.0 Constant-Rate Pumping Test Results ................................................................

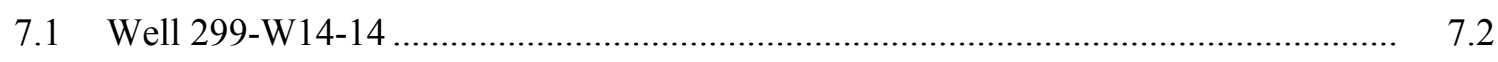

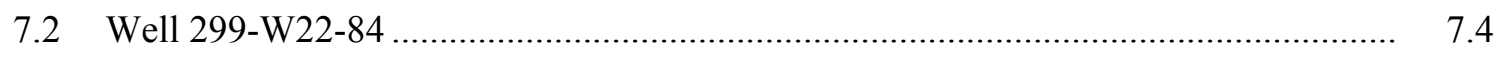

$8.0 \quad$ In-Well Vertical Flow Assessments ................................................................... 8.1

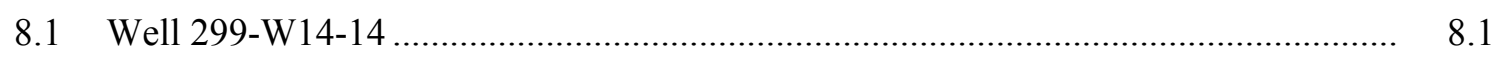

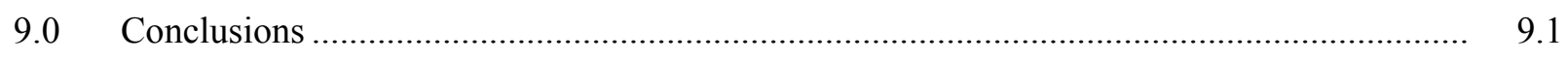

9.1 Slug-Test and Constant-Rate Pumping Test Results .......................................... 9.1

9.2 Tracer-Dilution Test Results ....................................................................... 9.3

$9.3 \quad$ Tracer-Pumpback Test Results ................................................................... 9.4

9.4 In-Well Vertical Flow-Test Results ............................................................... 9.4

9.5 Groundwater-Flow Characterization Results................................................... 9.5

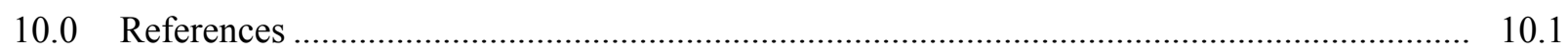




\section{Figures}

$1.1 \quad$ Location Map of Wells Tested During Fiscal Year 2002 ................................................. 1.3

2.1 Stratigraphic Relationships of Various Hydrogeologic Units ......................................... 2.2

2.2 Hydrogeologic Cross Section Through 200-West and 200-East Areas ............................... 2.3

3.1 Predicted Slug-Test Response for Nonelastic Formation, Elastic Formation, and High Hydraulic Conductivity Sand-Pack Conditions .............................................................. 3.3

3.2 Predicted Slug-Test Response: Negative Finite-Thickness Skin Conditions....................... 3.6

3.3 Predicted Slug-Test Derivative Response: Negative Finite-Thickness Skin Conditions ........ 3.7

3.4 Predicted Slug-Test Response: Positive Finite-Thickness Skin Conditions ....................... 3.8

3.5 Hypothetical Tracer-Dilution Pattern Indicative of Vertical In-Well Downward Flow ......... 3.14

3.6 Characteristic Log-Log Drawdown and Drawdown Derivative Plots for Various Hydrogeologic Formation and Boundary Conditions ....................................................... 3.17

4.1 Comparison of Hydraulic Conductivity Estimates Obtained Using Bouwer and Rice and Type-Curve Analysis Methods

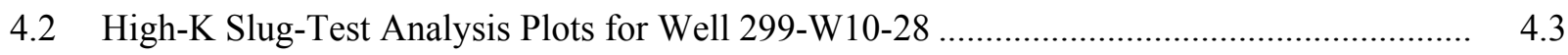

4.3 Predicted Slug-Test Type-Curve Response Plots for Well 299-W14-14 ............................ 4.4

4.4 Comparison of Low-Stress, Slug-Test Response Plots for Well 299-W14-14 _.................... 4.5

4.5 Selected Slug-Test Analysis Plots for Well 299-W14-14 ...............................................

4.6 Heterogeneous Formation Slug-Test Response Exhibited for Well 299-W14-18 ................. 4.7

4.7 Selected Slug-Test Analysis Plots for Well 299-W14-18 …............................................ 4.9

4.8 Heterogeneous Formation Slug-Test Response Exhibited for Well 299-W22-84 ….............. $\quad 4.10$

4.9 Selected Slug-Test Analysis Plots for Well 299-W22-84 …...........................................

4.10 Selected Slug-Test Analysis Plots for Well 299-W22-85 ...................................................

4.11 High-K Slug-Test Analysis Plot for Well 299-E33-338 _.................................................

5.1 Average Tracer-Dilution Test Results Within Well 299-W14-14 ..................................... 5.3 
5.2 Average Tracer-Dilution Test Results Within Well 299-W22-84 ................................... 5.5

$6.1 \quad$ Tracer-Pumpback Test Results for Well 299-W14-14 ................................................... 6.2

6.2 Tracer-Pumpback Test Results for Well 299-W22-84 ................................................... 6.4

7.1 Type-Curve and Derivative Plot Analysis of Drawdown and Recovery Test Data for Pumping Well 299-W14-14 Using Best-Fit Parameters ...................................................... 7.3

7.2 Type-Curve and Derivative Plot Analysis of Drawdown and Recovery Test Data for Pumping Well 299-W14-14 Assuming $\mathrm{K}_{\mathrm{D}}=0.1$

7.3 Type-Curve and Derivative Plot Analysis of Drawdown and Recovery Test Data for Pumping Well 299-W22-84

8.1 Tracer Concentration Versus Depth-Response Patterns Within Well 299-W14-14 During Tracer-Dilution Testing and Calculated In-Well Vertical Flow Velocities 


\section{Tables}

1.1 New and Recently Constructed RCRA Wells Characterized in Fiscal Year 2002 ................ 1.2

1.2 Pertinent As-Built Information for Wells Tested During Fiscal Year 2002 ........................ 1.4

3.1 Detailed Hydrologic Characterization Elements ........................................................... 3.1

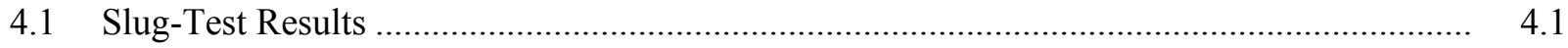

$5.1 \quad$ Tracer-Dilution Test Results for Well 299-W14-14 _................................................. 5.3

5.2 Tracer-Dilution Test Results for Well 299-W22-84 ...................................................... 5.5

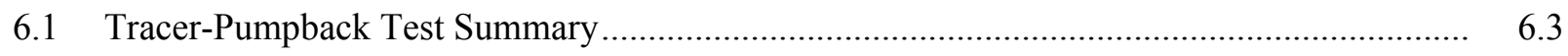

7.1 Constant-Rate Pumping Test Summary …...........................................................

8.1 In-Well Vertical Flow Velocity Assessment Based on Tracer-Dilution Pattern Assessment for Well 299-W14-14 .....................................................................................

9.1 Hydraulic Property Summary for Slug- and Constant-Rate Pumping Tests ........................ 9.2

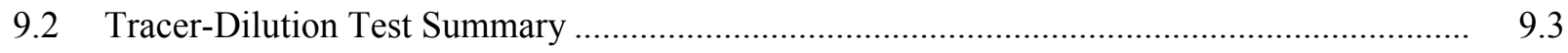

9.3 Groundwater-Flow Characterization Results Based on Trend-Surface Analysis .................. 9.5 


\subsection{Introduction}

The Hanford Groundwater Monitoring Project managed by Pacific Northwest National Laboratory (PNNL) assesses the potential for onsite and offsite migration of contamination within the shallow, unconfined, aquifer system and the underlying, upper, basalt-confined aquifer system at the Hanford Site. As part of this activity, detailed hydrologic characterization tests are conducted within wells at selected Hanford Site locations to provide hydraulic property information and groundwater-flow characterization for the unconfined aquifer. Results obtained from these characterization tests provide hydrologic information that supports the needs of the Resource Conservation and Recovery Act (RCRA) facility hydrogeologic characterization and sitewide groundwater monitoring and modeling programs and reduces the uncertainty of groundwater-flow conditions at selected locations on the Hanford Site.

This report is the fourth of a series that provides the results of detailed hydrologic characterization tests conducted within new and recently constructed Hanford Site wells within the unconfined aquifer system. In the previous three reports, Spane et al. (2001a, 2001b, 2002) presented the results of hydrologic characterization tests conducted during FY 1999, 2000, and 2001. In this report, results of tests conducted during FY 2002 are provided. The various characterization elements employed in FY 2002, as part of the detailed hydrologic characterization program, include the following:

- $\quad$ slug tests - to evaluate well-development conditions and provide preliminary hydraulic property information (e.g., hydraulic conductivity) for the design of subsequent hydrologic tests

- tracer-dilution tests - to determine the vertical distribution of hydraulic conductivity and/or groundwater-flow velocity within the well-screen section and to identify vertical flow conditions within the well column

- tracer-pumpback tests - to characterize effective porosity and average, aquifer, groundwater-flow velocity

- constant-rate pumping tests - to provide quantitative hydraulic property information (e.g., transmissivity, hydraulic conductivity, storativity, specific yield) when conducted in concert with tracerpumpback phase and analysis of drawdown and recovery data

- in-well vertical flow assessment - to determine in-well vertical flow conditions within the wellscreen section

- barometric response evaluation - to compare the characteristics of well response to barometric fluctuations, estimate vadose zone transmission characteristics, and remove barometric pressure effects from hydrologic test responses

- groundwater-flow characterization - to quantify the direction of groundwater flow and hydraulic gradient conditions. 
New and recently constructed RCRA wells selected for characterization during FY 2002 are listed in Table 1.1. The RCRA wells are all constructed of 10.16-centimeter-diameter stainless-steel casing with wire-wrapped stainless-steel screens and sand pack. These wells were constructed either to replace older wells that are going dry because of the declining water table (e.g., 200-West Area) or for additional area coverage. All wells tested are screened across the water table and penetrate approximately the top 9 to 11 meters of the aquifer. Two of the test wells (299-W14-14 and 299-W22-84) were selected for detailed hydrologic characterization. Well 299-W14-14 was previously slug tested shortly after construction in FY 1999 and used as an observation well during a constant-rate pumping test of nearby well 299-W14-15 during FY 2001. These test results are reported in Spane et al. (2001a and 2002). Figure 1.1 shows the location of the wells tested during FY 2002 in relationship to the 200-West and 200-East Areas of the Hanford Site. The boundaries of the various RCRA waste management areas are shown on site maps contained in Hartman et al. (2002). Table 1.2 provides pertinent as-built and well-completion information for the identified new wells. This report presents the results of hydrologic characterization conducted at these well sites during FY 2002.

Table 1.1. New and Recently Constructed RCRA Wells Characterized in Fiscal Year 2002

\begin{tabular}{||c|c||}
\hline Well & RCRA Waste Management Area \\
\hline \hline $299-W 10-28$ & SST T \\
\hline $299-W 14-14$ & SST TX-TY \\
\hline 299-W14-18 & SST TX-TY \\
\hline 299-W22-84 & SST S-SX \\
\hline 299-W22-85 & SST S-SX \\
\hline 299-E33-338 & SST B-BX-BY \\
\hline \multicolumn{2}{|c|}{ SST = Single-shell tank. } \\
\hline
\end{tabular}




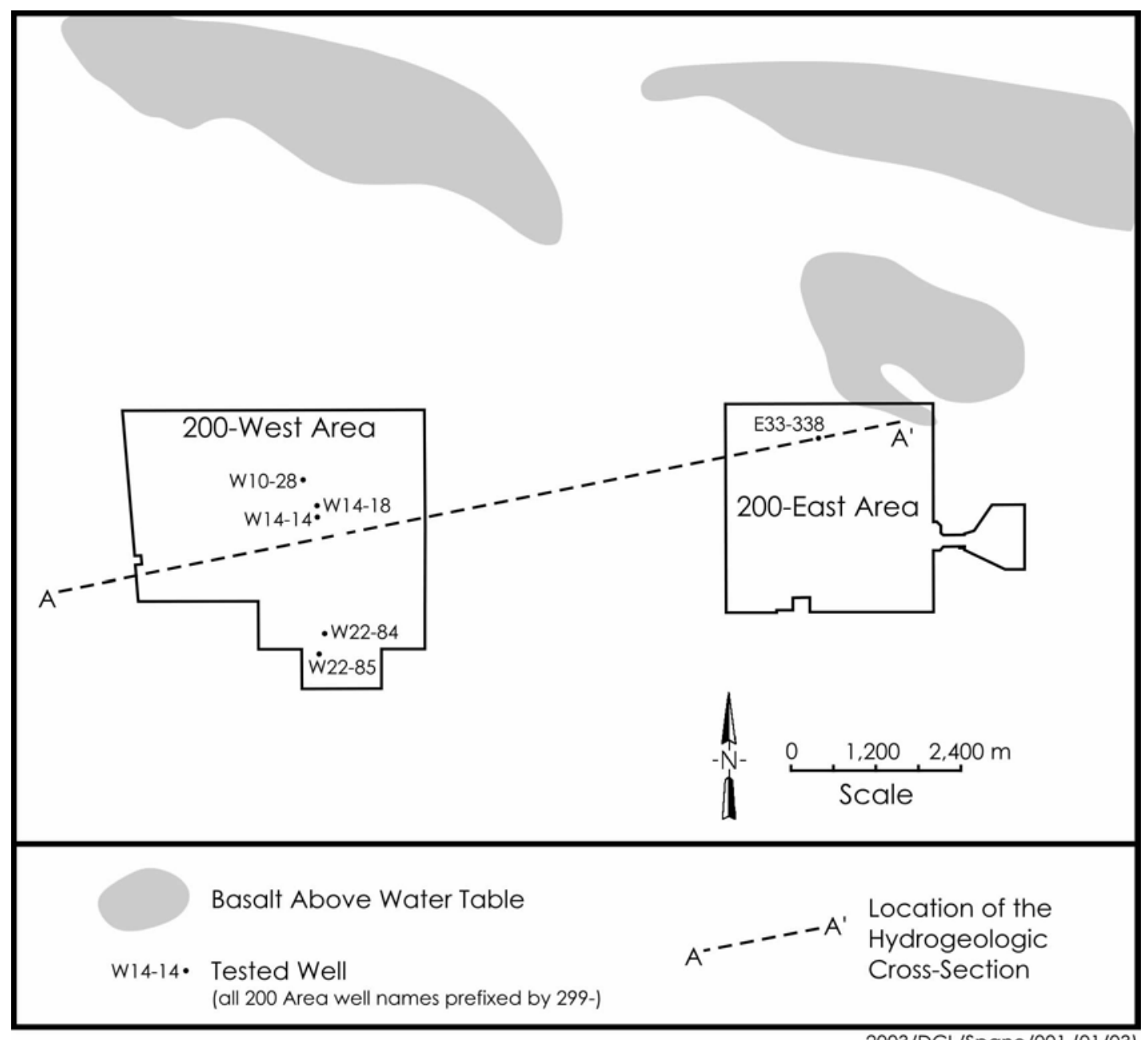

2003/DCL/Spane/001 (01/03)

Figure 1.1. Location Map of Wells Tested During Fiscal Year 2002 
Table 1.2. Pertinent As-Built Information for Wells Tested During Fiscal Year 2002

\begin{tabular}{||c|c|c|c||}
\hline Well & $\begin{array}{c}\text { Ground Surface/Brass-Cap } \\
\text { Elevation, m, } \\
\text { MSL (NAVD88) }\end{array}$ & $\begin{array}{c}\text { Well-Screen Depth Below } \\
\text { Ground Surface/Brass } \\
\text { Cap, m }\end{array}$ & $\begin{array}{c}\text { Saturated Well-Screen } \\
\text { Section, m } \\
\text { MSL (NAVD88) }\end{array}$ \\
\hline \hline 299-W10-28 & 206.10 & $68.64-79.31$ & $\begin{array}{c}137.21-126.79 \\
(10.42)^{(a)}\end{array}$ \\
\hline 299-W14-14 & 204.62 & $66.14-76.81$ & $\begin{array}{c}136.73-127.81 \\
(8.92)\end{array}$ \\
\hline 299-W14-18 & 204.26 & $66.46-77.13$ & $\begin{array}{c}137.05-127.13 \\
(9.92)\end{array}$ \\
\hline 299-W22-84 & 207.79 & $70.71-81.38$ & $\begin{array}{c}136.81-126.41 \\
(10.40)\end{array}$ \\
\hline 299-W22-85 & 203.68 & $66.18-76.82$ & $\begin{array}{c}136.87-126.86 \\
(10.01)\end{array}$ \\
\hline
\end{tabular}




\subsection{Hydrogeologic Setting}

The hydrogeology of the 200-West and 200-East Areas is described in terms of two classification systems used for the Hanford Site consolidated groundwater model: the first is based on hydrogeologic units (Thorne et al. 1993) and the second is based strictly on geology (Lindsey 1995). The hydrogeologic classification system subdivides units based on texture, which correlates to hydraulic properties. This geologic classification is based on the lithologic and stratigraphic relationships defined by Lindsey (1995). A comparison of the two classifications is shown in Figure 2.1. The major classification system difference in the vicinity of the 200 Areas is the grouping of the lower sand-dominated portion of Lindsey's upper Ringold with Ringold gravel Units E and C to form Thorne's hydrogeologic Unit 5. A general west-to-east cross section in Figure 2.2 shows the hydrogeologic units underlying the 200-West and 200-East Areas. Figure 1.1 shows the surface trace of the cross section in relationship to the test wells described in this report.

The brief hydrogeologic description for the 200-West and 200-East Areas presented below is taken primarily from Spane et al. (2001a, 2001b, 2002), which is based on the following reports: Graham et al. (1984), Lindsey et al. (1992), Connelly et al. (1992a, 1992b), Thorne et al. (1993), Lindsey (1995), and Williams et al. (2000).

\subsection{Hydrogeology of the 200-West Area}

The aquifer system above the basalt bedrock in the 200-West Area comprises two aquifer systems: an unconfined aquifer and an underlying, locally confined aquifer. The unconfined aquifer lies almost entirely within Unit 5 of the Ringold Formation (geologic Unit E; see Figure 2.1) and is composed of fluvial, gravel-dominated sediments with a fine-sand matrix. The FY 2002 results for test wells located in the 200-West Area reflect this hydrogeologic unit (Unit 5). Sediment within Unit 5 exhibits variable degrees of cementation, ranging from partially to well developed. Cemented zones up to several meters thick and extending laterally over several hundred meters have been identified in the 200 -West Area. Thin, laterally discontinuous, sand and silt beds also are intercalated in the gravelly deposits.

The lower Ringold mud (Unit 8), consisting of overbank and lacustrine deposits, underlies the unconfined aquifer. This mud unit is continuous over the entire 200-West Area but is absent just north of the 200-West Area. The lower mud unit generally thickens and dips to the south and southwest. The top of the mud unit, which has an irregular surface, forms the lower boundary of the unconfined aquifer in the 200-West Area.

The lower mud separates the unconfined aquifer from an underlying confined aquifer, which is composed of Unit 9 (the gravel portion of geologic Unit A). Unit 9 is composed of fluvial gravels with lesser amounts of intercalated sands and silts. This basal unit, which lies directly above the basalt bedrock, thickens and dips to the south and southwest. The uppermost basalt formation beneath the 200-West Area is the Saddle Mountains Basalt. 
Hydrogeologic Column

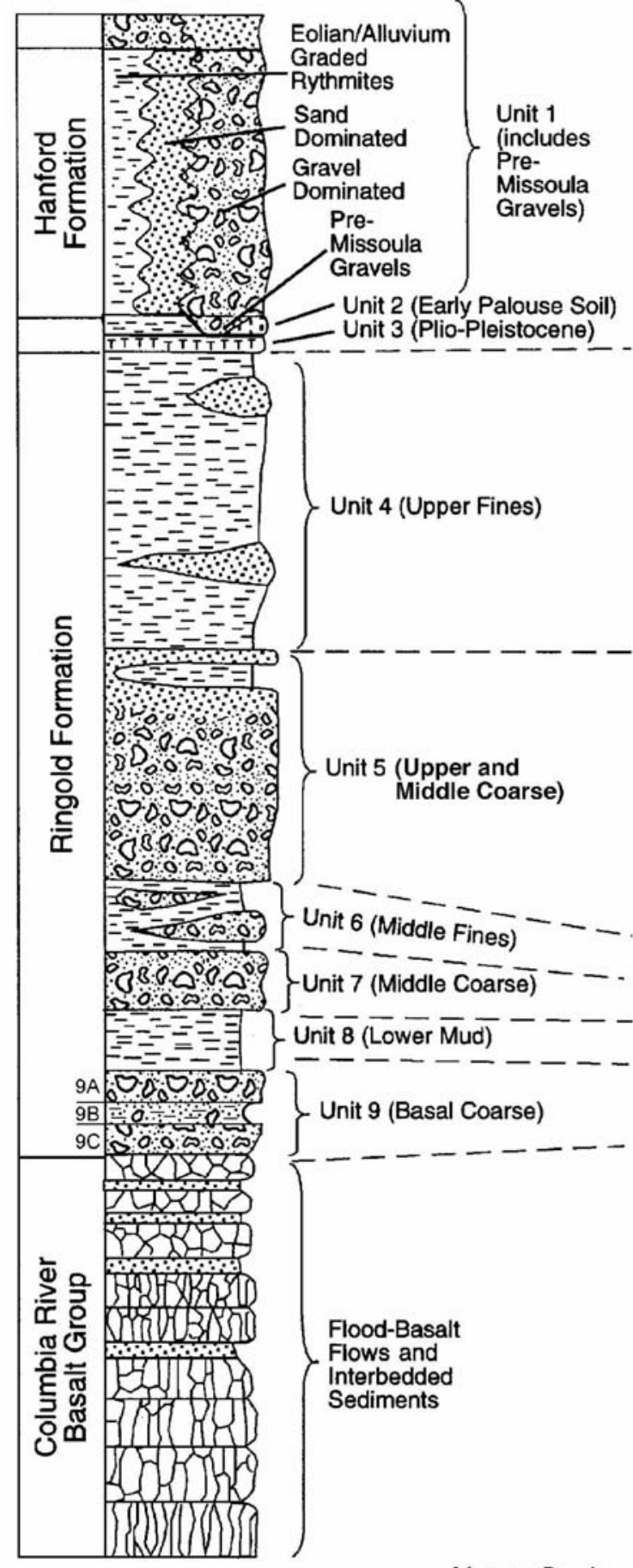

After Thorne et al. (1993)
Geologic Column

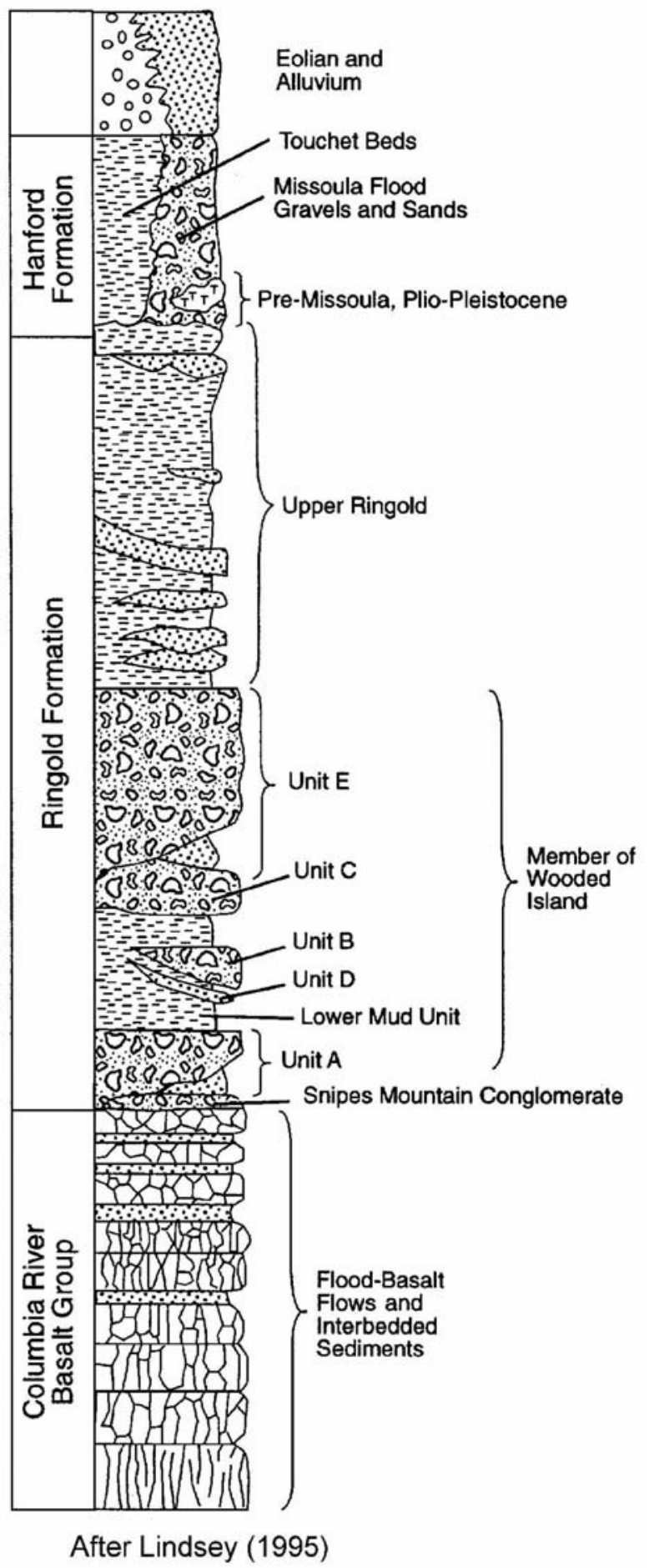

2000/DCL/Spane/001

Figure 2.1. Stratigraphic Relationships of Various Hydrogeologic Units 

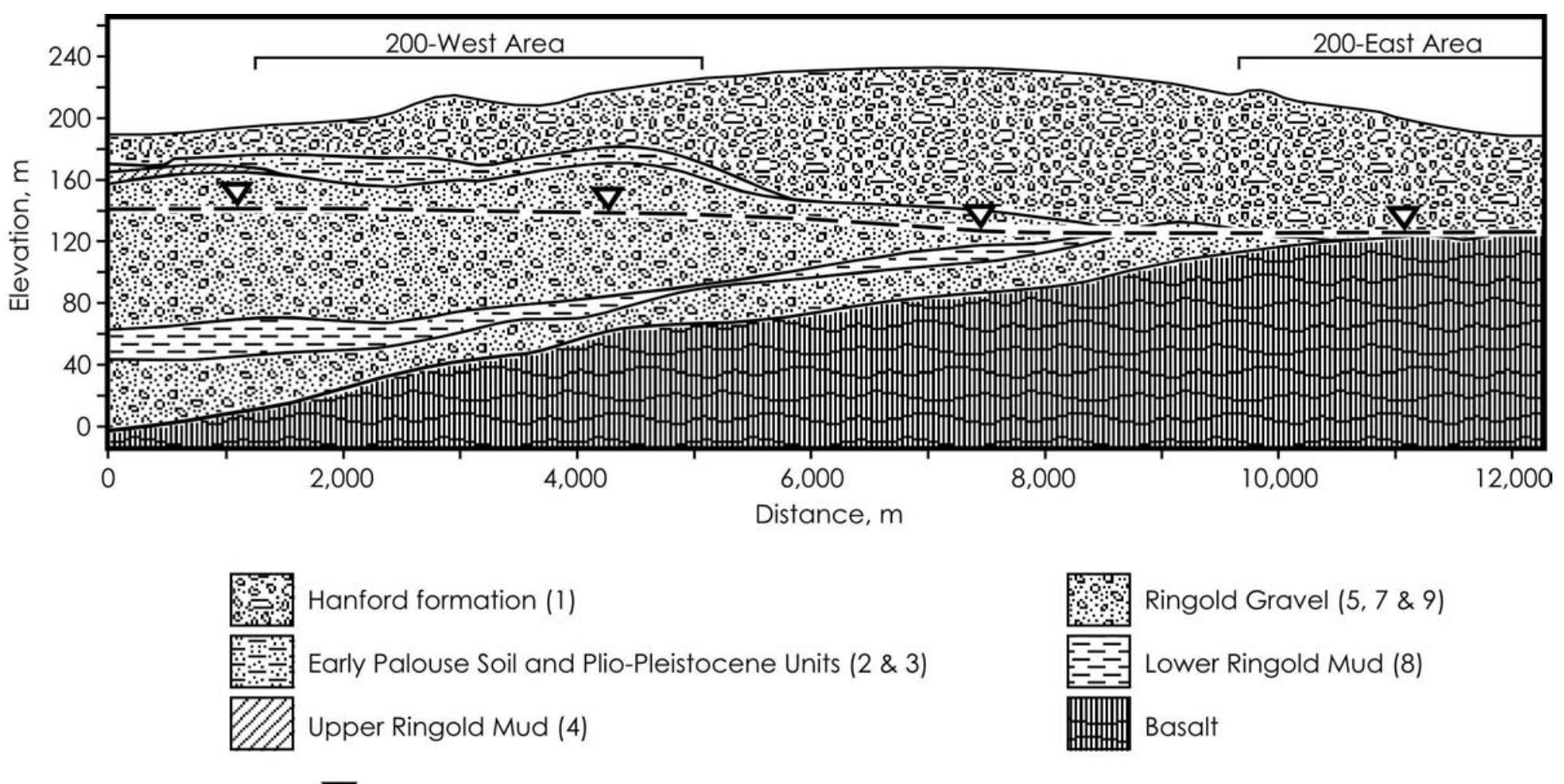

- - $\underline{\boldsymbol{\nabla}}-1998$ Water Table

2000/DCL/Spane/002

Figure 2.2. Hydrogeologic Cross Section Through 200-West and 200-East Areas (adapted from Spane et al. 2001a, 2001b) 


\subsection{Hydrogeology of the 200-East Area}

As in the 200-West Area, the aquifer system above the basalt in the 200-East Area consists of the unconfined aquifer and, in some places, a locally confined aquifer that underlies Unit 8 (lower Ringold mud). The unconfined aquifer within the 200-East Area lies within the Hanford formation (Unit 1) and/or Ringold Formation gravel (Units 5, 7, and 9) (see Figure 2.1). In the northern part of the 200-East Area, the unconfined aquifer is thin in locations where the basalt surface forms subsurface highs. In these locations, the unconfined aquifer lies almost entirely within Unit 1. Most wells recently tested within the 200-East Area (Spane et al. 2001a, 2001b, 2002) are reflective of reworked Ringold gravel Unit E of Plio-Pleistocene age. This unit consists primarily of unconsolidated gravel- and sand-dominated sediments. These undifferentiated sediments represent reworking of the Ringold Formation deposits from either the ancestral Columbia River or Missoula flood events. Because of the preponderance of unconsolidated gravel and sand deposits, this unit generally exhibits higher permeabilities than older, non-reworked hydrogeologic units within the Ringold Formation.

The lower boundary of the unconfined aquifer in the 200-East Area is defined by the top of Unit 8 , the top of Unit 9B (a fine-grained subunit of Unit 9), or the top of basalt. To the north of the 200-East Area, the lower Ringold Formation units and underlying upper basalt flows were extensively eroded by the Missoula floods at the time the Hanford formation was deposited. Previous reports have indicated that direct hydrogeologic communication between the unconfined and underlying, upper, basalt-confined aquifer is likely in these areas (Gephart et al. 1979; Graham et al. 1984; Spane and Webber 1995).

Ringold Formation Unit 8, which represents the confining mud unit separating the overlying, unconfined aquifer from the underlying, confined, basal Ringold aquifer within Unit 9, is composed primarily of low-permeability, fluvial overbank, paleosol, and lacustrine silts and clay, with minor amounts of sand and gravel. As indicated in Figure 2.1, Unit 9 is composed of local subunits. Unit 9B consists of poorly characterized silt- to clay-rich zones and represents a relatively thin, low-permeability, local confining unit within the basal Ringold gravel. East of the 200-East Area near the 216-B-3 Pond, confining Units 8 and 9B extend above the regional water table.

Subunits 9A and 9C are composed primarily of fluvial gravels and collectively make up the Ringold confined aquifer within the southern part of the 200-East Area and near the 216-B-3 Pond east of the 200-East Area. The Ringold confined aquifer is defined by the lateral boundary of confining layer Unit 8 . Where Unit 8 has been removed by erosion, the basal Ringold gravel forms part of the unconfined aquifer. The Ringold confined aquifer thickens to the south and is bounded below by the top of the Saddle Mountains Basalt. 


\subsection{Detailed Test Characterization Methods}

This report provides the results of detailed hydrologic characterization tests conducted within newly constructed Hanford Site wells during FY 2002. Detailed characterization tests performed included groundwater-flow characterization, barometric response evaluation, slug tests, single-well tracer tests (tracer-dilution, tracer-pumpback, and in-well vertical flow tests), and constant-rate pumping tests. Table 3.1 provides a summary of the various hydrologic characterization elements. More in-depth descriptions of the methods used to analyze slug tests, various single-well tracer tests, and constant-rate pumping tests are provided in the following sections, and are taken primarily from Spane et al. (2001a, 2001b, 2002).

\subsection{Slug Tests}

Because of their ease of implementation and relatively short duration, slug tests are commonly used to provide initial estimates of hydraulic properties (e.g., range and spatial/vertical distribution of hydraulic conductivity, K). Because of the small displacement volumes employed during slug tests, hydraulic properties determined using this characterization method are representative of conditions relatively close to the well. For this reason, slug-test results are commonly used to design subsequent hydrologic tests having greater areas of investigation (e.g., slug interference [Novakowski 1989; Spane 1996; Spane et al. 1996], constant-rate pumping tests [Butler 1990; Spane 1993]).

Table 3.1. Detailed Hydrologic Characterization Elements

\begin{tabular}{|c|c|c|}
\hline Element & Activities & Results $^{\text {(a) }}$ \\
\hline $\begin{array}{l}\text { Groundwater-flow } \\
\text { characterization }\end{array}$ & $\begin{array}{l}\text { Trend-surface analysis of well } \\
\text { water-level data }\end{array}$ & $\begin{array}{l}\text { Quantitative determination of groundwater-flow } \\
\text { direction and hydraulic gradient }\end{array}$ \\
\hline $\begin{array}{l}\text { Barometric response } \\
\text { evaluation }\end{array}$ & $\begin{array}{l}\text { Well water-level response } \\
\text { characteristics to barometric } \\
\text { changes }\end{array}$ & $\begin{array}{l}\text { Aquifer-/well-model identification, vadose zone } \\
\text { property characterization, correction of hydrologic } \\
\text { test responses for barometric pressure fluctuations }\end{array}$ \\
\hline Slug test & $\begin{array}{l}\text { Multistress-level tests conducted } \\
\text { at each well site }\end{array}$ & Local $\mathrm{K}_{\mathrm{h}}$, $\mathrm{T}$ of aquifer surrounding well site \\
\hline Tracer-dilution test & $\begin{array}{l}\text { Monitoring dilution of admin- } \\
\text { istered tracer at injection well site }\end{array}$ & Determination of $\mathrm{v}_{\mathrm{w}}$ and vertical distribution of $\mathrm{K}_{\mathrm{h}}$ \\
\hline Tracer-pumpback test & $\begin{array}{l}\text { Pumping/monitoring of } \\
\text { recovered tracer and associated } \\
\text { pressure response in monitor } \\
\text { wells }\end{array}$ & Local- to intermediate-scale $\mathrm{n}_{\mathrm{e}}$ and $\mathrm{v}_{\mathrm{a}}$ \\
\hline In-well vertical tracer test & $\begin{array}{l}\text { Monitoring the vertical move- } \\
\text { ment of tracer within the well } \\
\text { screen }\end{array}$ & $\begin{array}{l}\text { Determination of } \mathrm{v}_{\mathrm{w}} \text { within the monitor well-screen } \\
\text { section }\end{array}$ \\
\hline Constant-rate pumping test & $\begin{array}{l}\text { Pumping/monitoring of pressure } \\
\text { response in monitor wells }\end{array}$ & $\begin{array}{l}\text { Intermediate to large-scale, } \mathrm{K}_{\mathrm{h}}, \mathrm{K}_{\mathrm{v}} / \mathrm{K}_{\mathrm{h}}, \mathrm{K}_{\mathrm{hx}} / \mathrm{K}_{\mathrm{hy}}, \mathrm{T}, \mathrm{S} \text {, } \\
\mathrm{S}_{\mathrm{y}}\end{array}$ \\
\hline
\end{tabular}


Slug tests conducted as part of the FY 2002 detailed characterization program were performed by removing a slugging rod (withdrawal test) of known displacement volume. Slug-withdrawal tests were employed rather than slug-injection tests (i.e., by rapidly immersing the slugging rod) because of their reported superior results for unconfined aquifer tests where the water table occurs within the well-screen section (e.g., Bouwer 1989). At all test sites, two different size slugging rods were used to impart varying stress levels for individual slug tests. The slug tests were repeated at each stress level to assess reproducibility of the test results. Comparison of the normalized slug-test responses is useful to assess the effectiveness of well development and the presence of near-well heterogeneities and dynamic skin effects, as noted in Butler et al. (1996). Dynamic skin conditions refer to the non-repeatability of test responses conducted at a particular stress level. This non-repeatability of test response is commonly associated with changing formational conditions near the well due to incomplete well development activities. As described in Butler (1998), hydraulic property characterization results obtained from wells exhibiting this type of test response dependence should be viewed with caution; with more credence given to test responses exhibiting less lagged response characteristics. Conversely, wells exhibiting repeatable slug test response behavior indicate a stable or static formation condition surrounding the well, and suggest that well has been effectively developed.

Based on volumetric relationships, the two different size slugging rods theoretically impart a slug-test stress level of 0.458 meter (low-stress tests) and 1.117 meters (high-stress tests) within a 0.1016 -meter inside diameter well. However, for conditions where wells are screened across the water table, as for the Hanford Site wells tested in FY 2002 and where the well-screen sand pack has a relatively high permeability, the actual stress level imposed on the test formation may be lower than the theoretical stress level. This is due to the added pore volume of the sand pack at the time of test initiation. For these situations, the actual slug-test stress level is determined by projecting the observed early test response back to the time of test initiation. For situations where the theoretical slug-test stress level, $\mathrm{H}_{\mathrm{o}}$, is greater than the observed or projected stress level, $\mathrm{H}_{\mathrm{p}}$, an equivalent well radius, $\mathrm{r}_{\mathrm{eq}}$, must be used instead of the actual well-casing radius, $r_{c}$, in the various analytical methods. The $r_{e q}$ can be calculated by using the following relationship presented in Butler (1998):

$$
\mathrm{r}_{\mathrm{eq}}=\mathrm{r}_{\mathrm{c}}\left(\mathrm{H}_{\mathrm{o}} / \mathrm{H}_{\mathrm{p}}\right)^{1 / 2}
$$

Two different methods were used for the slug-test analysis: the semiempirical, straight-line analysis method described in Bouwer and Rice (1976) and Bouwer (1989) and the type-curve-matching method for unconfined aquifers presented in Butler (1998). A description of the slug-test analysis methods is presented in the following sections. Analysis details and results for slug tests conducted at each of the test wells during FY 2002 are provided in Chapter 4.

\subsubsection{Bouwer and Rice Method}

The Bouwer and Rice method is a well-known technique and is widely applied in the analysis of slug tests. A number of analytical weaknesses, however, limit the successful application of the Bouwer and Rice method for analyzing slug-test response. These weaknesses constrain its application to slug-test responses that exhibit steady-state flow, isotropic conditions, no well-skin effects, and no elastic (storage) formation response. Unfortunately, these limitations are commonly ignored, and the Bouwer and Rice 
method is applied to slug-test responses that do not meet the test analysis criteria. A more detailed discussion on the analytical limitations of the Bouwer and Rice method is provided in Hyder and Butler (1995), Brown et al. (1995), and Bouwer (1996).

For slug tests exhibiting elastic storage response, it should be noted that improved estimates can be obtained if analysis criteria specified in Butler $(1996,1998)$ are observed. Figure 3.1 shows the predicted, normalized, slug-test response for three well/aquifer-test conditions: (1) nonelastic formation, (2) elastic formation, and (3) elastic formation with high-K sandpack effects. The test responses were calculated using the Kansas Geological Survey (KGS) model described in Liu and Butler (1995) for the given test conditions listed in Figure 3.1. As shown, the presence of elastic aquifer storage (i.e., specific storage, $\mathrm{S}_{\mathrm{s}}$ ) and effects of a high-permeability sand pack cause curvilinear test responses (concave upward) that deviate from the predicted linear, nonelastic formation response. When this diagnostic curvilinear response is exhibited in the slug-test response, Butler $(1996,1998)$ recommends that the late-time test analysis be employed (i.e., the normalized head segment between 0.3 and 0.2 ) when using the Bouwer and Rice (1976) method. As shown in Figure 3.1, the two elastic curvilinear test responses over the specified latetime segment closely parallel the nonelastic test-formation response. This indicates that quantitative estimates for K can be obtained using the Bouwer and Rice method over a wide range of test-response conditions (nonelastic or elastic formation, high-K sandpack effects), if the proper analysis criteria are applied.

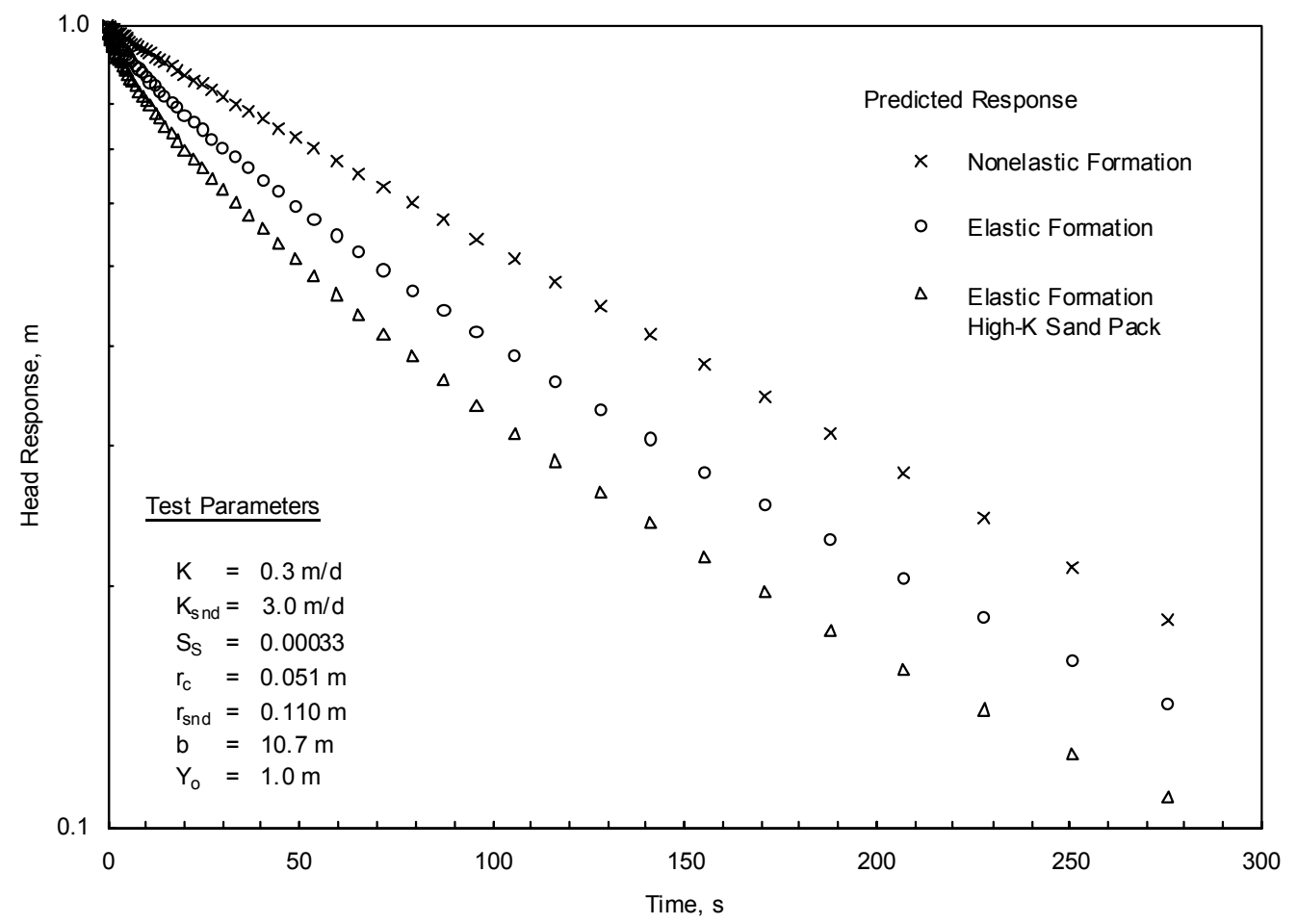

Figure 3.1. Predicted Slug-Test Response for Nonelastic Formation, Elastic Formation, and High Hydraulic Conductivity Sand-Pack Conditions 
Because of its semi-empirical nature, analytical results obtained using the Bouwer and Rice method (i.e., in contrast to results obtained using the type-curve-matching method) may be subject to error.

Bouwer and Rice (1976) indicated that the K estimate, using their analysis method, should be accurate to within $10 \%$ to $25 \%$. Hyder and Butler (1995) state an accuracy level for the Bouwer and Rice method within $30 \%$ of actual for homogeneous, isotropic formations, with decreasing levels of accuracy for more complex well/aquifer conditions (e.g., well-skin effects). For these reasons, greater credence is generally afforded the analytical results obtained using the type-curve-matching approach, which has a more rigorous analytical basis.

\subsubsection{Type-Curve Method}

Because the type-curve method can use all or any part of the slug-test response in the analysis procedure, it is particularly useful to analyze unconfined aquifer tests. The method also does not have any of the aforementioned analytical weaknesses of the Bouwer and Rice method. To facilitate the standardization of the slug-test type-curve analyses, a set of initial analysis parameters was assumed:

- a vertical anisotropy, $\mathrm{K}_{\mathrm{D}}$, value of 1

- a specific storage, $\mathrm{S}_{\mathrm{s}}$, value of $0.00001 \mathrm{~m}^{-1}$

- the well-screen interval below the water table was assumed to be equivalent to the test-interval section.

To standardize the slug-test type-curve-matching analysis for all slug-test responses, a $1 \mathrm{~K}_{\mathrm{D}}$ was assumed. As noted in Butler (1998), this is the recommended value to use for slug-test analysis when setting the aquifer thickness to the well-screen length. Previous investigations by F. A. Spane (author) have indicated that single-well slug-test responses are relatively insensitive to $\mathrm{K}_{\mathrm{D}}$; therefore, the use of an assumed (constant) value of 1 over a small well-screen section (i.e., $\leq 10$ meters long) is not expected to have a significant impact on the determination of hydraulic conductivity, $\mathrm{K}_{\mathrm{h}}$, from the type-curvematching analysis.

To facilitate the unconfined aquifer slug-test type-curve analysis, an $\mathrm{S}_{\mathrm{s}}$ value of $0.00001 \mathrm{~m}^{-1}$ was used for all initial analysis runs. After initial matches were made through adjustments of transmissivity, $\mathrm{T}$, additional adjustments of $S_{s}$ were then attempted to improve the overall match of the test-response pattern. In most test cases, slight modifications (i.e., increasing $S_{s}$ ) were made to the input $S_{s}$ values to improve the final analysis type-curve matches. However, other factors influence the shape of the slug-test curve (e.g., skin effects, $K_{D}$ ). For this reason, the $S_{s}$ estimate obtained from the final slug-test analyses is considered to be of only qualitative value and should not be used (as in the case for $K_{h}$ ) for quantitative applications.

For the slug-test analysis, the well-screen interval below the water table (rather than the sandpack interval) was used to represent the test interval. This was based on the assumption that the formation materials within the screened interval have a higher permeability than the sandpack; therefore, testresponse transmission is expected to propagate faster laterally from the well screen to the surrounding test formation than vertically within the sandpack zone. In reality, only small differences exist between 
individual well-screen and sandpack-interval lengths (i.e., compared to the aquifer-thickness relationship) and, subsequently, no significant differences in analysis results would be expected. This assumption is consistent with recommendations listed in Butler (1996).

The type-curves analyses presented in this report were generated using the KGS program described in Liu and Butler (1995). The KGS program is not strictly valid for the boundary condition, where the water table occurs within the well screen. However, a comparison of slug-test type curves generated from converted pumping test type curves (as described in Spane 1996), which accounts for this boundary effect, indicates very little difference in predicted responses when compared to the KGS model results. Because of this close comparison and the fact that the KGS program calculates slug-test responses directly and can be applied more readily for analysis of the slug-test results, it was used as the primary type-curve-analysis method in this report.

\subsubsection{Heterogeneous Formation Analysis}

Inherent in the analytical methods discussed above is the assumption that the test interval is homogeneous. A number of formation heterogeneities, however, can exert significant influence on slug-test response. Recognized heterogeneous formation conditions affecting slug-test response include multilayers of varying hydraulic properties within the well-screen section, presence of linear boundaries, and radial variation of hydraulic properties with distance from the well (i.e., radial boundaries).

The effects of multi-layer conditions within the test interval have been examined previously by Butler et al. (1994) and Butler (1998). These studies indicate that the presence of multi-layers of varying hydraulic properties cannot be distinguished from the pattern of the slug-test response. For well screens that fully penetrate a heterogeneous, multi-layer aquifer, the hydraulic conductivity estimated from the slug test will be an arithmetic average of the thickness-weighted $\mathrm{K}_{\mathrm{h}}$ values of the individual layers. For well screens that partially penetrate the upper-part of a multi-layer aquifer, the hydraulic conductivity estimated from the test also will represent a thickness-weighted arithmetic average, as long as significant vertical leakage does not occur from layers underlying the test interval.

The effects of linear boundaries on slug-test response have been examined previously by Karasaki et al. (1988) and Guyonnet et al. (1993). These effects are largely dependent on the nature of the boundary (i.e., no-flow or constant-head), proximity to the test well, and the storage characteristics of the aquifer and well. As a generalization, Guyonnet et al. (1993) state that no-flow boundaries cause the slug-test response to deviate from and delay recovery, while constant-head boundaries cause the slug test to recover faster than that predicted for a corresponding unbounded system response. Karasaki et al. (1988) accounts for the presence of linear boundaries within slug-test response by employing image-well theory. The effect of linear boundaries is very similar to that imposed by radial boundaries, which is discussed in the following paragraphs.

The effects of radial variations of hydraulic properties surrounding the test well have been investigated previously in studies examining slug tests in the presence of finite-thickness skin (e.g., Moench and Hsieh 1985). A finite-thickness skin is essentially a radial boundary condition surrounding a fullypenetrating well, where the inner zone has significantly different hydraulic properties than the outside zone. A negative skin refers to the case where $\mathrm{K}_{\mathrm{h}}$ of the inner zone is much greater than that of the outer 
zone (i.e., $\mathrm{K}_{1}>>\mathrm{K}_{2}$ ); while a positive skin denotes the opposite condition (i.e., $\mathrm{K}_{1}<<\mathrm{K}_{2}$ ). The effects of a radial boundary on slug-test response are largely a function of the contrast in $\mathrm{K}_{\mathrm{h}}$ for the inner and outer zone, the storage characteristics, and radial distance from the well to the boundary.

Figure 3.2 shows the predicted slug-test responses for a negative finite-thickness skin condition, where the inner zone has a $K_{h} 100$ times greater than the outer zone, for various selected radial boundary distances $(0.5,1,2$ meters). The test responses were generated using the KGS program referenced in Section 3.1.2, which can account for finite-thickness well-skin conditions. For comparison purposes, homogeneous slug-test responses (i.e., no radial boundary) for the $\mathrm{K}_{\mathrm{h}}$ representative solely of the inner and outer zones also are provided. For this example, the storativities, S, for both zones are set equal and representative of elastic formation conditions $\left(S_{1}=S_{2}=0.001\right)$. An examination of Figure 3.2 indicates several important features. During early-test times, all the radial boundary examples follow the inner zone response (i.e., homogeneous formation response), with the duration of coincidence being directly associated with distance to the radial boundary. The presence of the radial boundary is exhibited by the departure from inner zone response, where the test response becomes flatter (recovery rate decreases) and transitions to a combined composite test response, reflective of the hydraulic properties inside and outside the radial boundary. Recognizing whether radial flow boundaries are present within the slug-test response may be difficult unless the transition period segments of the test are distinct. Recognizing the presence of radial boundaries, however, is more apparent when slug test derivative plots are employed.

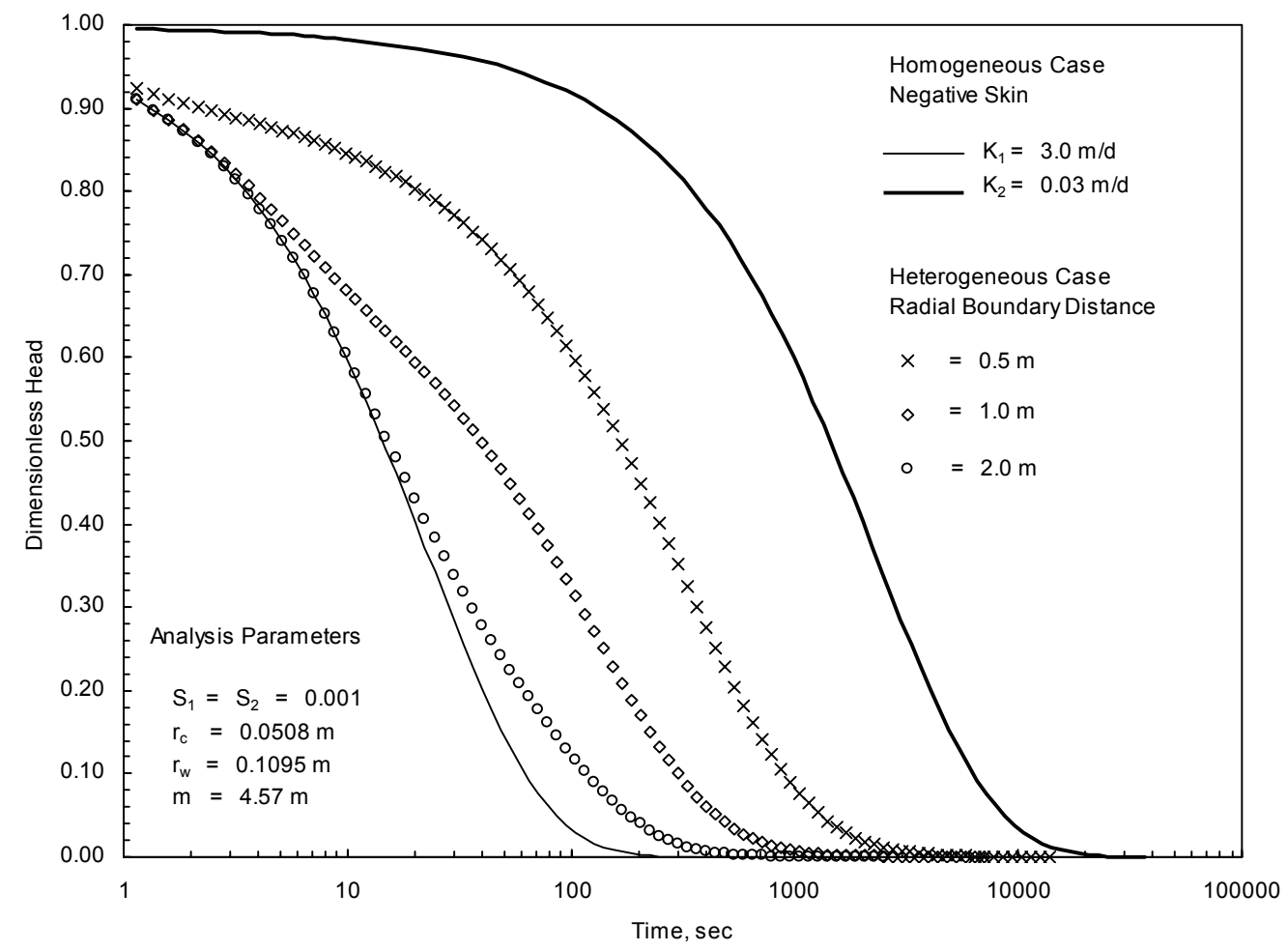

Figure 3.2. Predicted Slug-Test Response: Negative Finite-Thickness Skin Conditions 
Figure 3.3 shows the predicted slug-test derivative responses for the same test conditions presented in Figure 3.2. As shown, radial boundaries for the distances greater than 0.5 meter are denoted by a derivative pattern exhibiting multiple peaks or a stair-step pattern, which is in contrast to the smooth, single peak derivative pattern exhibited by homogeneous formations. For radial distances extremely close (e.g., $<0.5$ meter) or far (e.g., $>5$ meters) from the test well, the presence of boundaries may not be detected within the test response.

Figure 3.4 shows the predicted slug-test responses for a positive finite-thickness skin condition, where the inner zone has a $\mathrm{K}_{\mathrm{h}} 0.01$ times that of the outer zone, for the same selected radial boundary distances $\left(0.5,1,2\right.$ meters) and test conditions examined for the negative skin case (only the $\mathrm{K}_{\mathrm{h}}$ values for the inner and outer zones are reversed). As for the previous negative-skin example, during early-test times, the various heterogeneous responses follow the inner zone response (i.e., homogeneous formation response), with the duration of coincidence being directly associated with distance to the radial boundary. The presence of the radial boundary is exhibited by the departure from inner zone response, where the test response becomes steeper (recovery rate increases), with test recovery becoming reflective of a combined composite test response reflective of the hydraulic properties inside and outside the radial boundary. The increased steepness in test response due to the presence of a radial boundary (positive-skin), becomes more apparent when type-curve analysis methods are used (i.e., in comparison to the Bouwer and Rice method). As discussed in Butler (1998), the analysis of slug tests affected by positive-skin conditions often requires use of homogeneous formation type curves with unrealistically low storativity values (i.e.,

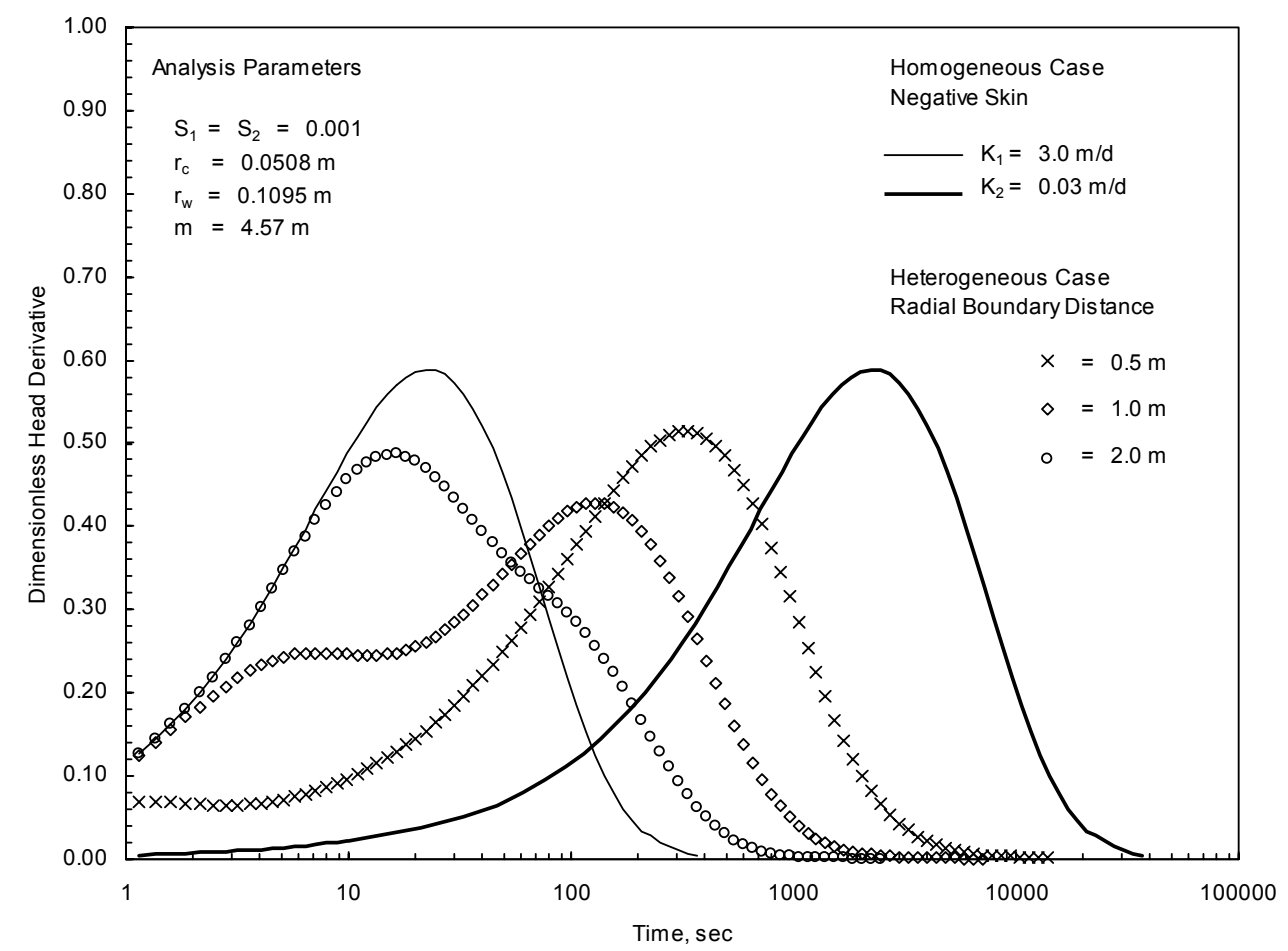

Figure 3.3. $\quad$ Predicted Slug-Test Derivative Response: Negative Finite-Thickness Skin Conditions 


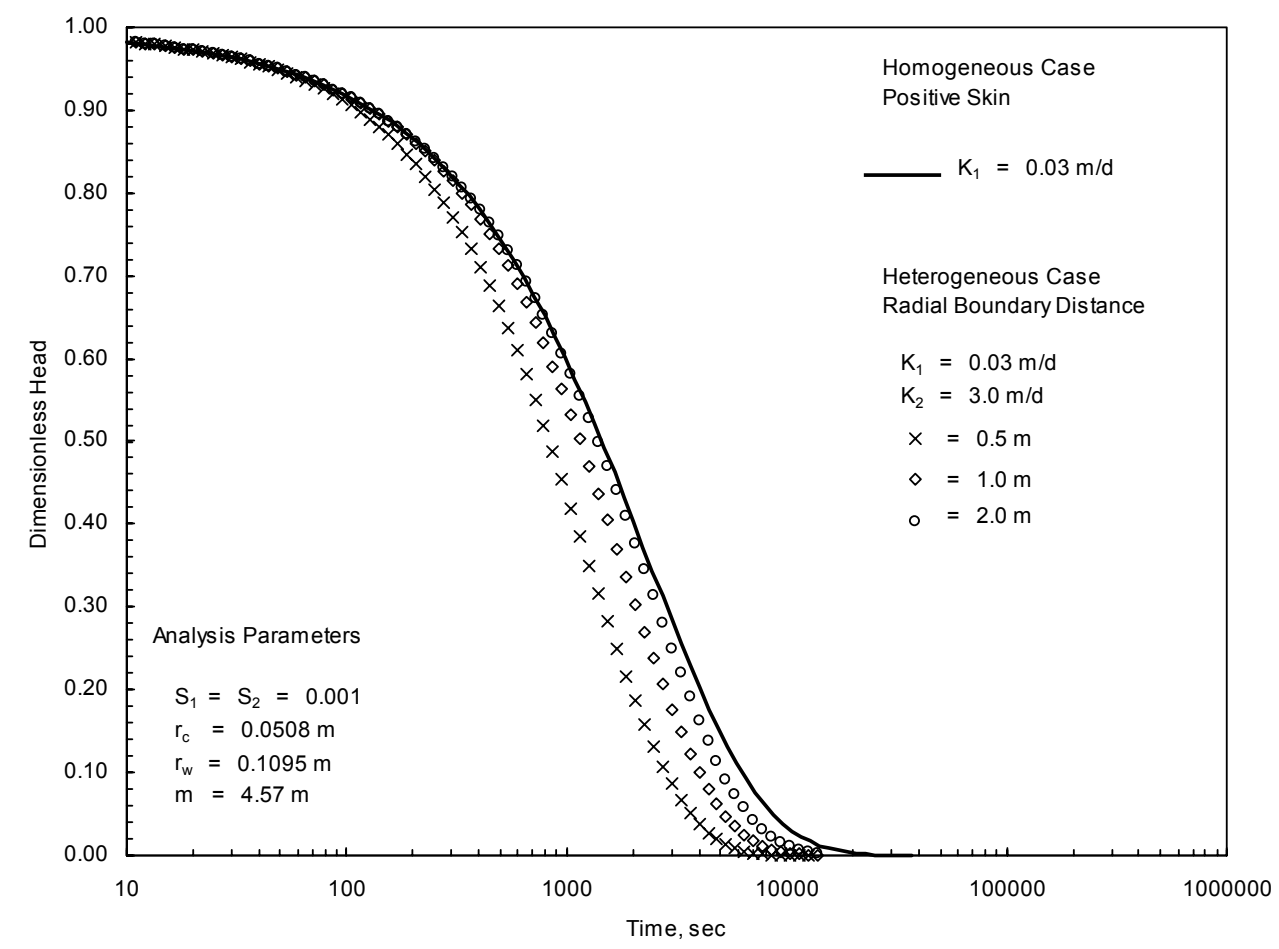

Figure 3.4. Predicted Slug-Test Response: Positive Finite-Thickness Skin Conditions

to match the entire test response). For this reason, Butler (1998) recommends the use of type-curve analysis for slug tests to detect whether positive skin-radial boundaries are present within the test response.

Three of the wells tested during FY 2002 exhibited effects of heterogeneous formation-radial boundary conditions (i.e., higher $\mathrm{K}$ inner zone). No complete slug-test response analyses (i.e., using $\mathrm{K}_{\mathrm{h}}$ values for the inner and outer zones) were attempted, however, using the finite-thickness, skin solution available within the KGS program (as shown in Figures 3.2, 3.3, and 3.4). This is due to the nonuniqueness of the analytical solution (i.e., similar test responses can be derived using different combinations of K, S and skin/inner zone thickness). For tests exhibiting heterogeneous formation behavior, the inner and outer zone test responses were analyzed independently using the homogeneous formation analysis approach. (Note: this is a departure from the complete analysis approach used in Spane et al. (2001b) for the analysis of three test wells exhibiting heterogeneous formation response conditions). For the outer zone test response, which is more representative of actual formation/aquifer conditions, the homogeneous formation analysis procedure outline in Butler (1998) was used. This procedure is similar to the method described in Section 3.1 to calculate the actual stress level, $\mathrm{H}_{\mathrm{p}}$. For a homogeneous formation analysis of the outer zone test response, the early-time test data reflecting the higher permeability inner zone is ignored and an initial, outer zone test stress level $\left(\mathrm{H}_{\mathrm{p}-\text { out }}\right)$ is calculated by projecting the observed, outer zone test data back to the time of test initiation. For analysis of the outer zone response, an equivalent well radius, $r_{\text {eq-out }}$, must be used instead of the actual well-casing radius, $r_{c}$, in the various analytical methods. The $\mathrm{r}_{\text {eq-out }}$ is calculated by using Equation 3.1, substituting $\mathrm{H}_{\mathrm{p} \text {-out }}$ for $\mathrm{H}_{\mathrm{p}}$ in the equation. 


\subsubsection{High Permeability Formation Analysis}

Slug-test response within highly permeable formations is commonly influenced by processes (e.g., inertial) that are not accounted for in the previously discussed analytical methods. For Hanford Site conditions, high permeability formation conditions can be expected when test responses exhibit any or all of the following characteristics:

- complete recovery within 10 seconds

- oscillatory recovery pattern

- overly-steep type-curve recovery and heightened derivative plot pattern

- concave downward Bouwer and Rice plot.

Slug tests exhibiting these response characteristics cannot be analyzed quantitatively using the Bouwer and Rice (Section 3.1.1) or type-curve (Section 3.1.2) methods. Methods that can be employed for analyzing unconfined aquifer tests exhibiting high permeability characteristics include, methods described in Springer and Gelhar (1991), Butler (1998), McElwee and Zenner (1998), Butler and Garnett (2000), and Zurbuchen et al. (2002). Because of the ease provided by a spreadsheet-based approach, the test analysis method presented in Butler and Garnett (2000) was used for tests exhibiting high permeability response characteristics. For FY 2002, only slug tests conducted at test wells 299-W10-28 and 299-E33-338 were analyzed using the high permeability analysis approach. These analysis results are discussed in Chapter 4.

\subsection{Single-Well Tracer Tests}

Single-well tracer tests can provide information on groundwater-flow characteristics (e.g., flow velocity) and aquifer properties (i.e., vertical distribution of $\mathrm{K}$, effective porosity, $\mathrm{n}_{\mathrm{e}}$ ). During FY 2002, single-well tracer tests included tracer-dilution, tracer-pumpback, and in-well vertical flow tracer. Performance and analysis methods for the various single-well tracer tests are described in the following sections.

\subsubsection{Tracer-Dilution Tests}

For the tracer-dilution test, a bromide solution of known concentration was mixed within the wellscreen section. The decline of tracer concentration (i.e., "dilution") with time within the well screen was monitored directly using a vertical array of bromide-specific ion-electrode sensors located at known depth intervals. The sensors were calibrated in the laboratory with standards of known bromide concentration prior to and following performance of the tracer-dilution test. Based on the dilution characteristics observed, the vertical distribution (i.e., heterogeneity) of hydraulic properties and/or in-well flow velocity can be estimated for the formation section penetrated by the well screen. The presence of vertical flow within the well screen can also be identified from the sensor/depth-dilution-response pattern. A description of the performance and analysis of tracer-dilution test characterization investigations is provided in Halevy et al. (1966), Hall et al. (1991), and Hall (1993). 
Essential design elements of a tracer-dilution test include establishing a known, constant tracer concentration within the test section by mixing or circulating the tracer solution in the wellbore/test interval and monitoring the decline of tracer concentration with time within the test interval.

The decline in tracer concentration within the wellbore can be analyzed to ascertain the hydraulic gradient, I (if the formation's $\mathrm{K}$ is known) or the test-interval $\mathrm{K}$ (if the hydraulic gradient is known) using the following analytical expression:

$$
\ln \left(\mathrm{C} / \mathrm{C}_{\mathrm{o}}\right)=-\left(\mathrm{Q}_{\mathrm{W}} \mathrm{t}\right) / \mathrm{V}_{\mathrm{W}}
$$

where $\mathrm{C}=$ concentration of the tracer in the test interval at time, $\mathrm{t}$

$\mathrm{C}_{\mathrm{o}}=$ initial concentration of the tracer at the start of the test

$\mathrm{Q}_{\mathrm{w}}=$ in-well lateral groundwater discharge within the well-test interval

$\mathrm{V}_{\mathrm{w}}=$ isolated test interval well volume.

For test-analysis purposes, Equation 3.2 is commonly rewritten to calculate the groundwater-flow velocity within the well, $\mathrm{v}_{\mathrm{w}}$, as follows:

$$
\mathrm{v}_{\mathrm{w}}=\mathrm{d}(\ln \mathrm{C}) / \mathrm{dt} /(-\mathrm{A} / \mathrm{V})
$$

where $\mathrm{A}=$ cross-sectional area within well screen; $\mathrm{L}^{2}$

$$
\mathrm{V}=\text { well volume over measurement section; } \mathrm{L}^{3} \text {. }
$$

As shown by Halevy et al. (1966), to take into account the cross-sectional/well-measurement volume effects of the emplaced in-well tracer-measurement system (downhole probe, cables), Equation 3.3 can be rewritten as

$$
\mathrm{v}_{\mathrm{w}}=\mathrm{d}(\ln \mathrm{C}) / \mathrm{dt} /-\left[2 \mathrm{r}_{\mathrm{w}} / \pi\left(\mathrm{r}_{\mathrm{w}}^{2}-\mathrm{r}_{\mathrm{t}}^{2}\right)\right]
$$

where $r_{w}=$ radius of well screen; $\mathrm{L}$

$r_{t}=$ equivalent radius of tracer-measurement system; $L$.

It should be noted that the calculated $\mathrm{v}_{\mathrm{w}}$ is not the groundwater-flow velocity within the aquifer, $\mathrm{v}_{\mathrm{a}}$. The $\mathrm{v}_{\mathrm{w}}$ is related to actual groundwater velocity within the aquifer by the following relationship:

$$
\mathrm{v}_{\mathrm{w}}=\mathrm{v}_{\mathrm{a}} \mathrm{n}_{\mathrm{e}} \propto
$$

where $\mathrm{n}_{\mathrm{e}}=$ effective porosity; dimensionless

$\propto=$ groundwater-flow-distortion factor; dimensionless, common range 0.5 to 4 . 
Various aspects of conducting tracer-dilution tests (i.e., test design, influencing factors) have been discussed previously by a number of investigators (e.g., Halevy et al. 1966; Freeze and Cherry 1979). Following completion of the tracer-dilution test, the tracer can be recovered from the formation by pumping, and the results analyzed to assess the effective porosity within the test interval. Tracer-pumpback tests are discussed in the following section.

Some investigators have noted differences in hydraulic property estimates obtained with tracerdilution techniques and other test methods (e.g., Drost et al. 1968; Kearl et al. 1988). These differences were attributed, in some cases, to distortions in the flow field caused by increased (or decreased) permeability near the well.

Analysis details and results for tracer-dilution tests conducted at each of the selected test wells during FY 2002 are provided in Chapter 5.

\subsubsection{Tracer-Pumpback Tests}

Detailed procedures to conduct standard, single-well, conservative tracer tests are provided in Pickens and Grisak (1981) and Molz et al. (1985). The tracer pumpback includes the following basic test procedure:

- emplace a conservative tracer (bromide) within the well/aquifer system

- define a prescribed residence (drift) time for the tracer to be dispersed within the aquifer

- withdraw the tracer from the well/aquifer system by pumping at a constant rate

- monitor tracer concentrations at the test well (bromide sensor/flow cell) and collect discrete groundwater samples for quantitative laboratory analysis.

The tracer-testing program relied on natural groundwater flow to emplace the tracer and did not include actual injection of the bromide tracer into the surrounding aquifer. Because of the relatively small area represented by the well (i.e., in comparison to the aquifer) and volumes of tracer involved, the results obtained from these tracer tests may be more susceptible to wellbore effects (e.g., $\propto$ and possible downgradient dead zone).

For the tracer-pumpback tests, a constant-rate pumping test is begun after the average tracer concentration had decreased (i.e., diluted) to a sufficient level within the well screen (usually a one-to-two order of magnitude reduction from the original tracer concentration). The objective of the pumpback test is to capture the tracer that has moved from the well into the surrounding aquifer. Tracer recovery is monitored qualitatively by measuring the tracer concentration at the surface using a bromide sensor/flow cell installed in the discharge line. Discrete samples are collected at the surface at preselected times for quantitative laboratory tracer analysis.

The time required to recover the center of tracer mass from the aquifer provides information concerning $n_{e}$ and $v_{a}$. $n_{e}$ is a primary hydrologic parameter that controls contaminant transport. Analytical 
methods available for the analysis of single-well, tracer injection/withdrawal tests include (in addition to the previously cited references) Güven et al. (1985), Leap and Kaplan (1988), and Hall et al. (1991). The procedure to analyze the tracer-pumpback results is based on a rearrangement of the equations presented in Hall et al. (1991), which combines the basic pore velocity groundwater-flow equation (Equation 3.6) with the regional advective flow-velocity equation (Equation 3.7) describing tracer-drift and -pumpback tests as reported in Leap and Kaplan (1988).

$$
\begin{gathered}
\mathrm{v}_{\mathrm{a}}=(\mathrm{K} \mathrm{I}) / \mathrm{n}_{\mathrm{e}} \\
\left.\mathrm{v}_{\mathrm{a}}=\left[\left(\mathrm{Q} \mathrm{t}_{\mathrm{p}}\right) / \pi \mathrm{n}_{\mathrm{e}} \mathrm{b}\right)\right]^{1 / 2} / \mathrm{t}_{\mathrm{t}}
\end{gathered}
$$

Combining and rearranging results in

$$
\mathrm{v}_{\mathrm{a}}=\left(\mathrm{Q} \mathrm{t}_{\mathrm{p}}\right) /\left(\pi \mathrm{bt} \mathrm{t}_{\mathrm{t}}^{2} \mathrm{KI}\right)
$$

and

$$
\mathrm{n}_{\mathrm{e}}=\left(\pi \mathrm{b} \mathrm{t}_{\mathrm{t}}^{2} \mathrm{~K}^{2} \mathrm{I}^{2}\right) /\left(\mathrm{Q} \mathrm{t}_{\mathrm{p}}\right)
$$

where $\mathrm{v}_{\mathrm{a}}=$ advective groundwater-flow velocity within the aquifer; $\mathrm{L} / \mathrm{T}$

$\mathrm{n}_{\mathrm{e}}=$ effective porosity; dimensionless

$\mathrm{K}=$ hydraulic conductivity; $\mathrm{L} / \mathrm{T}$

$\mathrm{I}=$ local hydraulic gradient; dimensionless

$\mathrm{b}=$ aquifer thickness; $\mathrm{L}$

$\mathrm{Q}=$ tracer-pumpback rate; $\mathrm{L}^{3} / \mathrm{T}$

$t_{p}=$ pumping time required to recover the center of mass of tracer emplaced into the aquifer

$t_{t}=$ total elapsed time equal to sum of the tracer drift time, $t_{d}$, (time from tracer emplacement to start of recovery pumping) and $t_{p}$.

The K values used in Equations 3.8 and 3.9 were determined from analysis of constant-rate pumping tests for the test well (i.e., during the tracer pumpback). The I value was determined using trend-surface analysis of water-level elevation measurements from nearby wells as described in Section 3.4. The $\mathrm{b}$ value was calculated directly from geologic information obtained for the well or projection from known geologic relationships at nearby wells.

To calculate the time required to recover the tracer center of mass emplaced into the aquifer, several steps were required. The bromide concentration versus time profile during the pumpback test was 
determined by laboratory analysis of discrete samples collected closely over time. The mass of tracer recovered with time was calculated, based on integrating the product of the exhibited tracer concentration profile and observed pumping rate during the test. The $t_{p}$ value, to the center of mass, was calculated by dividing the tracer mass recovered by the actual tracer mass transported into the aquifer. To calculate the actual tracer mass within the aquifer, the mass within the well-screen column and surrounding well sandpack at the start of the pumpback test was subtracted from the initial mass emplaced in the well. The mass within the well screen was determined by multiplying the known well-screen volume by the average concentration, which was calculated by the final readings of the bromide sensors used during the tracerdilution test. The sensors were removed generally within 2 hours of initiation of the tracer pumpback; therefore, their final readings are representative of initial pumpback conditions. For calculating the tracer mass within the sandpack, the study assumed that the tracer concentration was the same as observed within the well screen. Sandpack volumetric calculations were based on available as-built information, a porosity of $25 \%$, and the assumption that $50 \%$ of the sandpack (i.e., the downgradient side) would be occupied by tracer.

The mathematical relationship to calculate half the tracer mass recovered during the pumpback, $\mathrm{M}_{50 \% \text {, }}$ which is the mass used to calculate the center of mass recovery time, $t_{p}$, then can be expressed as:

$$
\mathrm{M}_{50 \%}=0.50\left(\mathrm{M}_{\mathrm{r}}-\mathrm{M}_{\mathrm{w}}\right) /\left(\mathrm{M}_{\mathrm{i}}-\mathrm{M}_{\mathrm{w}}\right)
$$

where $\mathrm{M}_{\mathrm{r}}=$ mass of tracer recovered during the tracer pumpback; $\mathrm{M}$

$\mathrm{M}_{\mathrm{w}}=$ mass of tracer within well screen and well sandpack at the beginning of the tracer pumpback; $M$

$\mathrm{M}_{\mathrm{i}}=$ mass of tracer initially emplaced in the well; $\mathrm{M}$.

The $t_{p}$ also was corrected (reduced) to account for the transit time of the pumped water from the pump intake to land surface (i.e., location where laboratory samples were collected).

Analysis details and results for tracer-pumpback tests conducted at each of the selected test wells are provided in Chapter 6.

\subsubsection{In-Well Vertical Flow Assessment}

As discussed in Section 3.2.1, the successful performance of tracer-dilution tests requires that lateral groundwater-flow conditions exist within the well fluid column. The presence of vertical flow is indicated during the initial phases of tracer dilution if a systematic, "stair-step," tracer-dilution pattern is exhibited for the respective depth settings of the bromide sensor. Figure 3.5 illustrates a hypothetical tracer-dilution pattern for various depths for a downward vertical flow condition within the well screen. As shown, the pattern evolves with time (after the tracer has been uniformly mixed within the well-screen section) as a result of the downward flow/mixing of nontracer groundwater. As shown in Figure 3.5, the pattern is characterized by a progressive extension of a constant tracer concentration for the sensors at greater depths, followed by a rapid decline of tracer on arrival of the downward flow mixture of tracer and nontracer groundwater. During late test times, the various tracer versus depth profiles exhibit a 


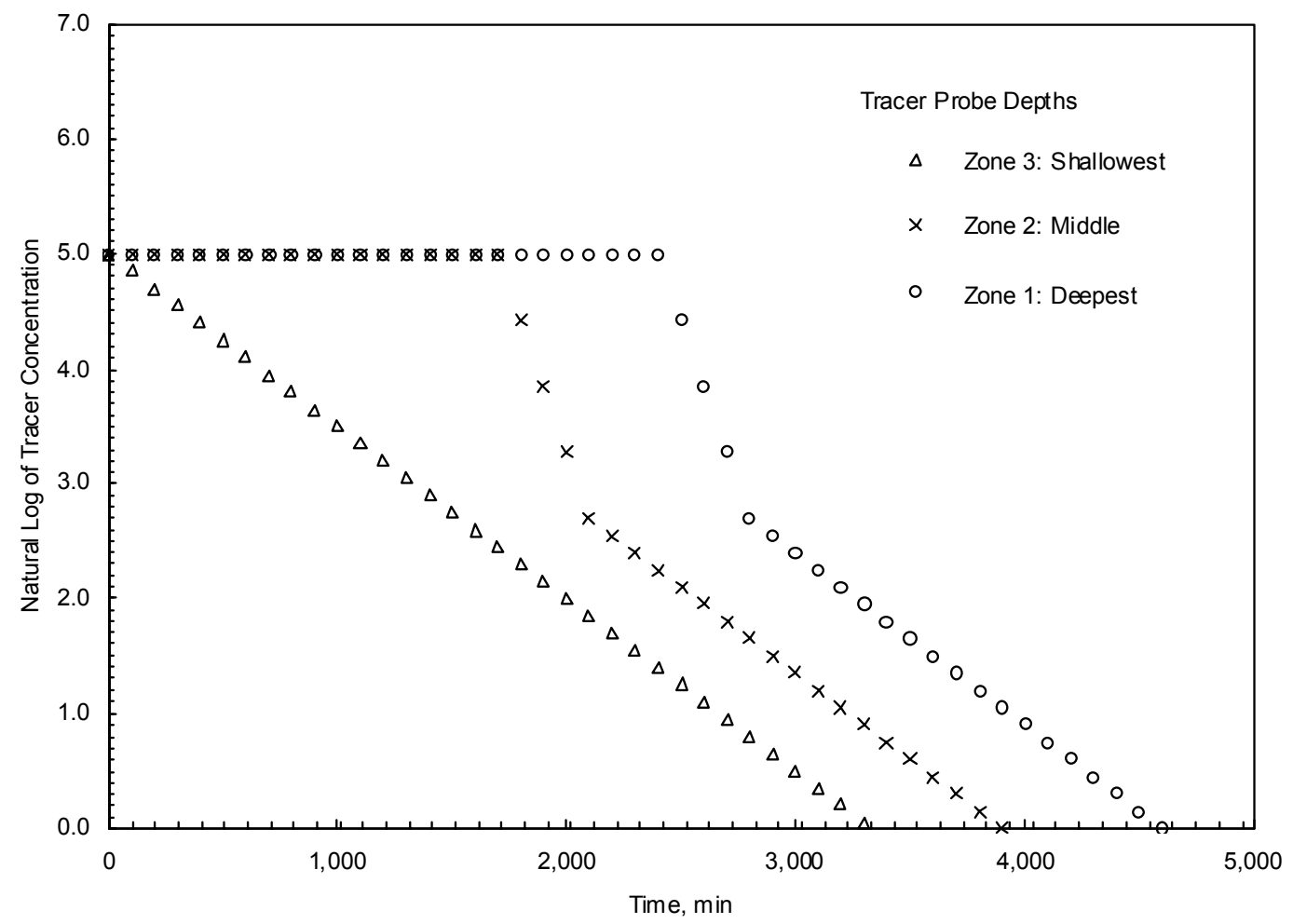

Figure 3.5. Hypothetical Tracer-Dilution Pattern Indicative of Vertical In-Well Downward Flow

parallel-linear pattern. $\mathrm{v}_{\mathrm{v}}$ can be calculated by using the arrival time of the tracer/nontracer groundwater mixture front at the various known depth/sensor spacings.

In previous site investigations, the presence of in-well vertical flow conditions was quantified using three different test methods: tracer-dilution pattern analysis, vertical flow-tracer tests, and electromagnetic vertical flow-meter surveys. As reported in Spane et al. (2001a, 2001b) close corroboration was exhibited between the three test methods. Because of budgetary constraints, in-well vertical flow conditions indicated by performing tracer-dilution tests were not investigated using either vertical flowtracer tests or electromagnetic surveys. Results of in-well vertical flow conditions for tests conducted during FY 2002 are based only on tracer-dilution pattern assessment and are presented in Chapter 8. As discussed in Sections 5.1 and 8.1, only well 299-W14-14 exhibited tracer dilution patterns indicative of in-well vertical flow conditions. A discussion of the other in-well vertical flow characterization methods not used during the FY 2002 well tests is presented in Spane et al. (2001a, 2001b).

\subsection{Constant-Rate Pumping Tests}

Drawdown and recovery water levels were measured during tracer-pumpback tests for the two RCRA wells selected for detailed hydrologic characterization (299-W14-14 and 299-W22-84). Water levels also were recorded at a nearby observation well (well 299-W14-15) during the testing of well 299-W14-14; however, malfunctioning of the pressure transducer system installed at the observation well site precluded its use for test analysis. Diagnostic analysis of the test responses was first conducted to determine test 
system characteristics and to identify test data that display infinite-acting radial flow behavior. Analysis of the drawdown and recovery phases of constant-rate discharge were then performed by type-curve fitting of log-log plots and, if appropriate, by straight-line analysis of semilogarithmic data plots of waterlevel change versus time. Test performance and methods used to analyze the results obtained from constant-rate testing are described in this section. Analysis details and results for each of the selected test wells are provided in Chapter 7.

\subsubsection{Test Methods and Equipment}

A 3-hp Grundfos ${ }^{\circledR}$ submersible pump was used to remove water during each pumping test. Flow rates were monitored with a surface turbine flow meter (inside diameter 0.025 meter, Arad $^{\circledR}$, model \#555061). Flow was adjusted manually using a gate valve to maintain constant-rate conditions. During the initial minutes of pumping (e.g., first 3 minutes), "instantaneous" flow rates were determined by measuring the time required for 19 liters of flow to register on the flow-meter dials. Flow-meter totalizer readings were recorded every 5 to 20 minutes during pumping. Druck, Inc., 0 to $10 \mathrm{psig}$, differential pressure transducers (model \# PDCR $^{\circledR}$ 1830-8388) were used to monitor water levels in the pumping well and the nearby monitor wells during the test. The transducers were vented at the surface to compensate automatically for atmospheric pressure fluctuations. Pressure transducer measurements were recorded using a Campbell Scientific, Inc. model CR-10X ${ }^{\mathrm{TM}}$ data logger.

Because tracer recovery also was being monitored during the tracer-pumpback test, part of the discharged groundwater was routed through a flow-through cell containing a bromide-selective ion probe, and a sampling port was used to collect water for laboratory analysis of the bromide tracer. These devices were downstream from the flow meter. The discharged water during the pumping test was collected in a tank truck for subsequent disposal at an effluent disposal facility.

\subsubsection{Barometric Pressure Effects Removal}

The analysis of well water-level responses during hydrologic tests provides the basis to estimate hydraulic properties that are important to evaluate groundwater-flow velocity and transport characteristics. Barometric pressure fluctuations, however, can have a discernible impact on well water-level measurements. Although the pressure transducers were vented to compensate for changes in barometric pressure, barometric pressure fluctuations also can cause changes in the water level in a well. This response effect is commonly ascribed to confined aquifers; however, wells completed within unconfined aquifers may also exhibit associated responses to barometric changes (Weeks 1979; Rasmussen and Crawford 1997). Water levels in unconfined aquifers typically exhibit variable time-lagged responses to barometric fluctuations. This time-lag response is caused by the time required for the barometric pressure change to be transmitted to the water table through the vadose zone compared to the instantaneous transmission of barometric pressure through the open well.

To determine the significance of barometric effects, water-level changes were monitored during a baseline period before or after each constant-rate discharge test and compared to the corresponding barometric pressure changes. Barometric pressures were obtained from the Hanford Meteorology Station (located immediately east of the 200-West Area), where they are recorded hourly. The barometric 
responses were then analyzed and removed from the recorded water levels using the multiple-regression deconvolution techniques described in Rasmussen and Crawford (1997) and Spane (1999, 2002). This technique relies on a least-squares fit of the water-level change to the corresponding barometric pressure change and time-lagged earlier barometric pressure changes. As noted in Spane (1999), under prevalent conditions in the 200-West and East Areas, no significant difference in removal efficiency was derived in using data collected at higher recording frequencies (e.g., 10 minutes). Therefore, data collected at a 1 -hour frequency were used in the process for barometric pressure removal.

Because barometric changes were recorded at a constant 1-hour frequency, the relationship between water level and barometric change can be represented as follows:

$$
\Delta \mathrm{h}_{\mathrm{w}}=\mathrm{X}_{0} \Delta \mathrm{h}_{\mathrm{ai}}+\mathrm{X}_{1} \Delta \mathrm{h}_{\mathrm{ai}-1}+\mathrm{X}_{2} \Delta \mathrm{h}_{\mathrm{ai}-2}+\ldots+\mathrm{X}_{\mathrm{n}} \Delta \mathrm{h}_{\mathrm{ai}-\mathrm{n}}
$$

where $\Delta \mathrm{h}_{\mathrm{w}}=$ water-level change over the last hour

$$
\begin{aligned}
\Delta \mathrm{h}_{\mathrm{ai}} & =\text { barometric pressure change over the last hour } \\
\Delta \mathrm{h}_{\mathrm{ai}-\mathrm{1}} & =\text { barometric pressure change from } 2 \text { hours to } 1 \text { hour previous } \\
\Delta \mathrm{h}_{\mathrm{a}-\mathrm{n}} & =\text { barometric pressure change from } \mathrm{n} \text { hours to (n-1) hour previous } \\
\mathrm{X}_{0} \ldots \mathrm{X}_{\mathrm{n}} & =\text { regression coefficients corresponding to time lags of } 0 \text { to } \mathrm{n} \text { hours } \\
\mathrm{n} & =\text { number of hours that lagged barometric effects are apparent. }
\end{aligned}
$$

After calculating $\mathrm{X}_{0} \ldots \mathrm{X}_{\mathrm{n}}$, simulated well water levels associated with the hourly barometric responses were calculated from the above equation for the baseline period. The results were then compared to the actual observed well water-level response for a "goodness of fit" evaluation. To remove barometric effects from water levels recorded during the constant-rate discharge test, a simulated well water-level response was calculated based on the hourly barometric changes that were observed over the test period. The predicted barometric induced response was then subtracted from the recorded pumping test water-level measurements. Analysis techniques described in the following section were then applied to the data after removal of barometric effects.

\subsubsection{Diagnostic Analysis and Derivative Plots}

Log-log plots of water level versus time have traditionally been used for diagnostic purposes to examine pumping test drawdown data. More recently, the derivative of the water level or pressure has also been used (Bourdet et al. 1989; Spane 1993) as a diagnostic tool. Use of derivatives has been shown to improve significantly the diagnostic and quantitative analysis of various hydrologic test methods (Bourdet et al. 1989; Spane 1993). The improvement in test analysis is attributed to the sensitivity of pressure derivatives to various test/formation conditions. Specific applications for which derivatives are particularly useful include the following: 
- determining formation-response characteristics (confined or unconfined aquifer) and boundary conditions (impermeable or constant head) that are evident within the test data

- assisting in the selection of the appropriate type-curve solution through combined type-curve/ derivative plot matching

- determining when infinite-acting, radial flow conditions are established and, therefore, when straight-line analysis methods are applicable.

Figure 3.6 shows log-log drawdown and derivative responses that are characteristic of some commonly encountered formation conditions. The early data, occurring before the straight-line approximation is valid or where wellbore storage is dominant, produce a steep, upward-trending derivative. The derivative normally decreases during transition from wellbore storage to radial flow and stabilizes at a constant value when infinite-acting, radial flow conditions are established. The stable derivative reflects the straight line on the semilog plot for infinite-acting radial flow. Unconfined aquifers and formations

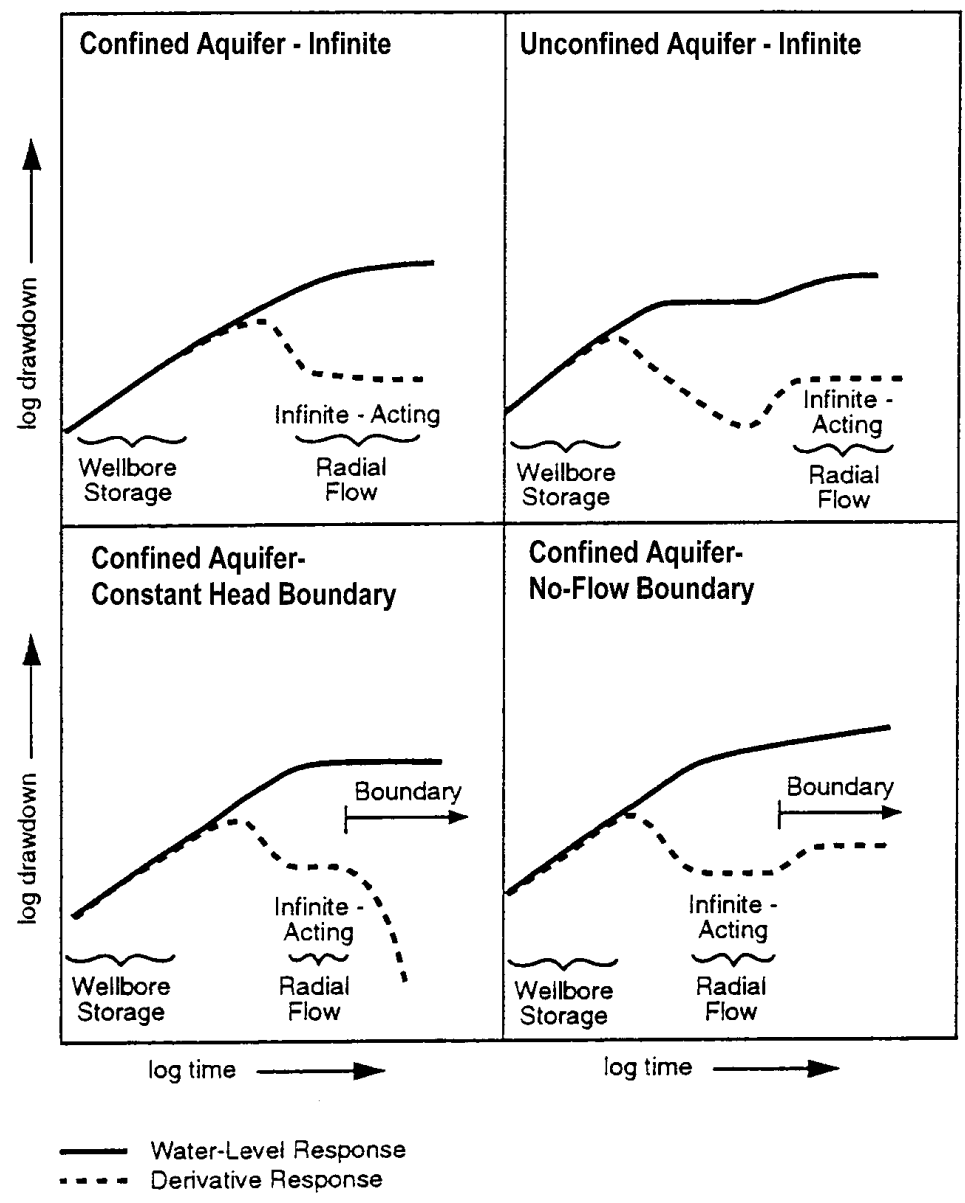

Figure 3.6. Characteristic Log-Log Drawdown and Drawdown Derivative Plots for Various Hydrogeologic Formation and Boundary Conditions 
exhibiting double-porosity characteristics (e.g., fractured media) may show two stable derivative sections at the same vertical position separated by a "valley" that represents the transition from one storage value to the other. Diagnostic derivative plots are also useful to identify boundary effects.

A linear, no-flow boundary will result in a doubling of the magnitude of the derivative. If radial flow is established before the influence of the boundary is seen, a stable derivative will occur for a time followed by an upward shift to twice the original value. Constant-head boundaries display a downward trend in the derivative, which may be preceded by a stable derivative if radial flow conditions occur before the boundary effect becomes dominant. For the diagnostic and test analysis aspects of this report, derivative responses were calculated using the DERIV program described in Spane and Wurstner (1993).

For pumping tests conducted as part of the FY 2002 detailed hydrologic characterization tests, the derivative of the water level with respect to the natural logarithm of time (i.e., essentially the slope of the semilog plot) was calculated and plotted on the log-log plots of drawdown versus time. For recovery data, the "Agarwal equivalent time function" (Agarwal 1980) was used to calculate the derivative and plotting recovery data. This time function accounts for the effects of the pumping period through a superposition technique. Diagnostic and analysis results of the log-log plots of water-level and associated derivative response for each well site constant-rate pumping test is provided in Chapter 7.

\subsubsection{Type-Curve-Matching Analysis Methods}

Type-curve-matching methods (Theis 1935; Hantush 1964; Neuman 1972, 1974, 1975) are commonly used to analyze pumping test responses. For this study, unconfined aquifer pumping test type curves were generated using the WTAQ3 computer program described by Moench (1997). WTAQ3 can be used to generate type curves that represent a wide range of test and aquifer conditions, including partially penetrating wells, confined or unconfined aquifer models, well-skin effects, and wellbore storage at both the stress (pump) and observation (monitor) well locations. The type-curve-generation program also allows for noninstantaneous release (drainage-delay factor) of water from the unsaturated zone during the pumping test. However, this was found to not be a significant factor in the analysis; therefore, the type curves used in the analyses for this report all reflect an instantaneous release of water, which was the approach used by Neuman $(1972,1974,1975)$.

In the type-curve-matching procedure, the log-log drawdown or recovery data and its associated derivative response for an individual well were matched simultaneously with dimensionless type-curve responses generated using WTAQ3 (Moench 1997) and the associated derivative plots obtained with the DERIV program (Spane and Wurstner 1993). The dimensionless responses depend on the assumed values of sigma, $\sigma=\mathrm{S} / \mathrm{S}_{\mathrm{y}}$, and vertical anisotropy, $\mathrm{K}_{\mathrm{D}}=\mathrm{K}_{\mathrm{v}} / \mathrm{K}_{\mathrm{h}}$. For initial type-curve-matching runs, the values for $\sigma$ and $\mathrm{K}_{\mathrm{D}}$ were set at 0.001 and 0.10 , respectively. Minor adjustments were made to the initial $\mathrm{K}_{\mathrm{D}}$ value to improve dimensionless curve matches of the data and associated derivative response patterns. The predicted response also is influenced by the assumed storativity, S, value because of its effect on wellbore storage. After an appropriate dimensionless match to the observed test data was obtained, dimensional curves were generated using the given well/test conditions (e.g., well radius, radial distance to observation well, average pumping rate) and making adjustments to aquifer properties $\left(\mathrm{T}, \mathrm{S}_{\mathrm{y}}\right)$ until the best match with the observed data was obtained. (Note that adjusting $\mathrm{S}_{\mathrm{y}}$ also changes the value of $\mathrm{S}$ because $\sigma$ was held constant.) 
Type-curve-matching methods are normally applied to observation well data and not to pumping wells because of the additional head losses that commonly occur at the pumped well. However, in previous analyses of test responses for the new RCRA wells in the 200-West Area (as reported in Spane 2001a, 2001b, and 2002), the fitting of type curves to stress well responses resulted in approximately the same $\mathrm{T}$ as fitting type curves to the observation well data. This suggests a high efficiency of the stress well, which incorporates a screen and sand pack in a relatively low-permeability aquifer. Therefore, little head loss appears to be associated with the movement of water into the well during pumping. Because of the similarities in well construction and development activities, it is assumed that the use of type-curve analysis of observed drawdown or recovery responses at pumping wells tested during FY 2002 is also considered to be appropriate. While this method is expected to provide quantitative estimates for $T$ and $\mathrm{K}_{\mathrm{h}}$, estimates obtained for $\mathrm{K}_{\mathrm{D}}$ and $\mathrm{S}_{\mathrm{y}}$ based solely on pumping well data analysis are considered only to be of qualitative values. This is attributed primarily to the relative insensitivity of pumping well type curves to $\mathrm{K}_{\mathrm{D}}$, and the relatively short-duration of pumping tests normally conducted on the Hanford Site (e.g., 240 to $360 \mathrm{~min}$ ).

\subsubsection{Straight-Line Analysis Methods}

For straight-line analysis methods, the rate of change of water levels within the well during drawdown and/or recovery is analyzed to estimate hydraulic properties. Because well effects are constant with time during constant-rate tests, straight-line methods can be used to analyze quantitatively the water-level response at both pumping and observation wells. The semilog, straight-line analysis techniques commonly used are based on either the Cooper and Jacob (1946) method (for drawdown analysis) or the Theis (1935) recovery method (for recovery analysis). These methods are theoretically restricted to the analysis of test responses from wells that fully penetrate nonleaky, homogeneous, isotropic, confined aquifers. Straight-line methods, however, may be applied under nonideal well and aquifer conditions if infiniteacting, radial flow conditions exist. Infinite-acting, radial flow conditions are indicated during testing when the change in pressure, at the point of observation, increases in proportion to the logarithm of time. As discussed above, the use of diagnostic derivative methods (Bourdet et al. 1989) makes it easier to identify the portions within the test data where straight-line analysis is appropriate. As will be discussed in Chapter 7, derivative analysis of the observed test responses indicated that infinite-acting, radial flow conditions were not established at any of the selected test well locations. Use of straight-line analysis methods, therefore, are not appropriate. The use of straight-line analysis methods is mentioned in this report, however, because they are commonly applied in the analysis of pumping test results.

\subsection{Groundwater-Flow Characterization}

To support the detailed hydrologic characterization program, groundwater-flow direction and hydraulic gradient conditions were calculated at the various test sites during the period of tracer testing. Groundwater-flow direction and hydraulic gradient were determined using the commercially available WATER-VEL (In-Situ, Inc. 1991) software program. Water-level elevations from neighboring, representative wells were used as input with the WATER-VEL program to calculate groundwater-flow direction and hydraulic gradient conditions. The program uses a linear, two-dimensional trend surface (least squares) to randomly located hydrologic head or water-level elevation input data. This method is similar also to the linear approximation technique described by Abriola and Pinder (1982) and Kelly and 
Bogardi (1989). Reports that demonstrate the use of the WATER-VEL program for calculation of groundwater-flow velocity and direction on the Hanford Site include Gilmore et al. (1992) and Spane (1999). Details and results for groundwater-flow characterization at two of the selected test wells are provided in Chapter 6. A summary of the results of groundwater-flow characterization is presented in Chapter 9. 


\subsection{Slug-Test Results}

Multiple slug tests were conducted at the six identified test wells during FY 2002. The slug tests were initiated by rapidly removing a slugging rod of known volume from the well-screen section. Two different size slugging rods were used during the testing program at each well to impose different stress levels on the test section. The stress levels for the two slugging rods are calculated to impose a slugwithdrawal test response of $0.458 \mathrm{~m}$ (low-stress tests) and $1.117 \mathrm{~m}$ (high-stress tests) within a 0.1016-m inside diameter well. As noted in Butler (1996), differences exhibited between slug tests conducted at different stress levels can be used to evaluate stress-dependence effects of the well (e.g., dynamic skin, well development), which are unrelated to aquifer characteristics. Methods used to analyze the slug test results are described in Section 3.1. A summary list of the hydraulic properties determined from slug testing is provided in Table 4.1. A comparison of the average hydraulic conductivity, $\mathrm{K}$, estimates obtained using the Bouwer and Rice and type-curve analysis methods is shown in Figure 4.1. As indicated, the Bouwer and Rice method provided consistently lower values (generally within 35\%) than the corresponding type-curve-derived estimates. This general pattern for analytical method comparison is consistent with findings reported in Hyder and Butler (1995) and Spane et al. (2001a, 2001b, 2002) description of the performance and analysis of slug tests conducted at each well site is provided below.

Table 4.1. $\quad$ Slug-Test Results

\begin{tabular}{|c|c|c|c|c|c|}
\hline \multirow[b]{2}{*}{ Test Well } & \multicolumn{2}{|c|}{ Test Parameters } & \multirow{2}{*}{$\begin{array}{c}\text { Bouwer and Rice } \\
\text { Analysis Method } \\
\text { Horizontal Hydraulic } \\
\text { Conductivity, } \mathrm{K}_{\mathrm{h}}{ }^{(\mathrm{b})} \\
(\mathrm{m} / \text { day })\end{array}$} & \multicolumn{2}{|c|}{ Type-Curve Analysis Method } \\
\hline & $\begin{array}{c}\text { Aquifer } \\
\text { Thickness }^{(\mathrm{a})} \\
(\mathrm{m}) \\
\end{array}$ & $\begin{array}{c}\text { Test Interval } \\
\text { Saturated } \\
\text { Thickness }(\mathrm{m}) \\
\end{array}$ & & $\begin{array}{c}\text { Horizontal Hydraulic } \\
\text { Conductivity, } \mathrm{K}_{\mathrm{h},}{ }^{(\mathrm{b})} \\
(\mathrm{m} / \text { day })\end{array}$ & $\begin{array}{c}\text { Specific Storage, } \\
\mathrm{S}_{\mathrm{S}}\left(\mathrm{m}^{-1}\right)\end{array}$ \\
\hline 299-W10-28 & 54.2 & 10.42 & NA & $\begin{array}{c}26.5-29.2^{(\mathrm{c})} \\
(27.9) \\
\end{array}$ & NA \\
\hline 299-W14-14 & 54.8 & 8.92 & $\begin{array}{c}2.26-2.35 \\
(2.31)\end{array}$ & $\begin{array}{c}3.02-3.41 \\
(3.22)\end{array}$ & $2.3 \mathrm{E}-04-6.6 \mathrm{E}-04$ \\
\hline 299-W14-18 & 52.8 & 9.92 & $\begin{array}{c}\text { Inner Zone: } 2.95-4.22 \\
(3.59) \\
\text { Outer Zone: } 0.37-0.40 \\
(0.39) \\
\end{array}$ & $\begin{array}{c}\text { Inner Zone: } 3.63-5.18 \\
(4.41) \\
\text { Outer Zone: } 0.52-0.56 \\
(0.54) \\
\end{array}$ & $\begin{array}{c}5.0 \mathrm{E}-06 \\
1.0 \mathrm{E}-06-1.0 \mathrm{E}-05\end{array}$ \\
\hline 299-W22-84 & 68.6 & 10.40 & $\begin{array}{c}\text { Inner Zone: } 3.57-5.39 \\
(4.48) \\
\text { Outer Zone: } 1.05-1.25 \\
(1.15) \\
\end{array}$ & $\begin{array}{c}\text { Inner Zone: } 4.54-6.35 \\
\text { (5.45) } \\
\text { Outer Zone: } 1.38-1.64 \\
(1.51) \\
\end{array}$ & $\begin{array}{l}1.0 \mathrm{E}-05 \\
1.0 \mathrm{E}-06\end{array}$ \\
\hline 299-W22-85 & 71.7 & 10.01 & $\begin{array}{c}\text { Inner Zone: } 21.3 \text { - } 30.1 \\
\text { (25.7) } \\
\text { Outer Zone: } 4.51-6.87 \\
(5.69)\end{array}$ & $\begin{array}{c}\text { Inner Zone: } 23.3-36.3 \\
\text { (29.8) } \\
\text { Outer Zone: } 5.96-9.50 \\
(7.73)\end{array}$ & $\begin{array}{l}1.0 \mathrm{E}-06-1.0 \mathrm{E}-05 \\
1.0 \mathrm{E}-05-1.0 \mathrm{E}-04\end{array}$ \\
\hline 299-E33-338 & 4.78 & 4.78 & NA & $\begin{array}{l}89^{(\mathrm{c})} \\
(89) \\
\end{array}$ & NA \\
\hline \multicolumn{6}{|c|}{$\begin{array}{l}\text { Note: For all test wells, } \mathrm{r}_{\mathrm{c}}=0.051 \text { meter; } \mathrm{r}_{\mathrm{w}}=0.110 \text { meter (see Nomenclature for definitions). } \\
\text { Number in parentheses is average. } \\
\text { (a) Determined, in most cases, from projection from neighboring wells. } \\
\text { (b) Assumed to be uniform within the well-screen test section. For tests exhibiting a heterogeneous formation response, } \\
\text { only outer zone analysis results are considered representative of in-situ formation conditions } \\
\text { (c) Standard analytical methods are not valid. Results based on high-K analysis method presented in Butler and Garnett } \\
(2000)\end{array}$} \\
\hline
\end{tabular}




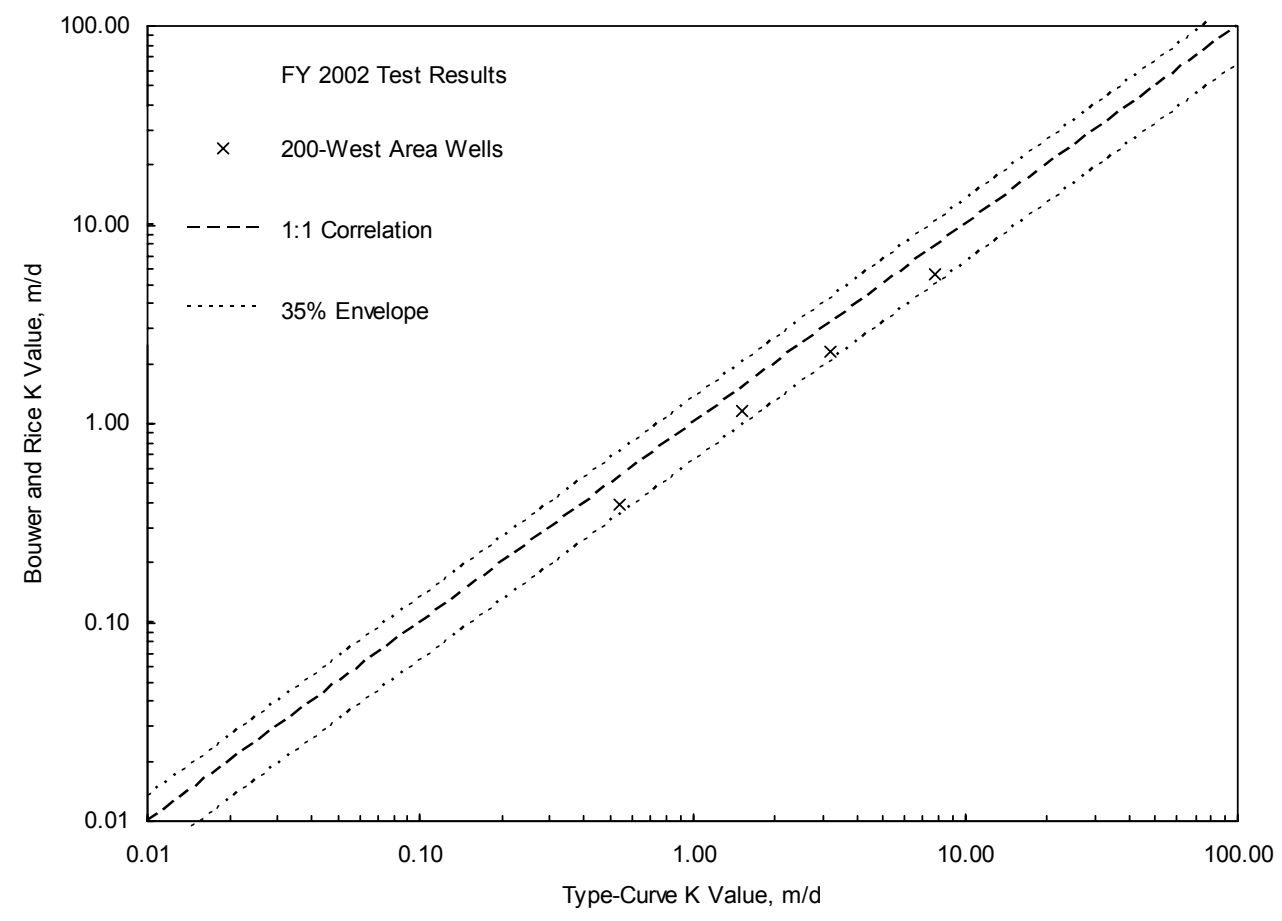

Figure 4.1. Comparison of Hydraulic Conductivity Estimates Obtained Using Bouwer and Rice and Type-Curve Analysis Methods

\subsection{Well 299-W10-28}

A total of eight slug tests (five high and three low stress) were conducted on December 11 and 12, 2001. Selected examples of the analysis plots for this well are shown in Figure 4.2. Rather rapid recoveries (90\% recovery within 3 seconds) were exhibited for all tests, and are indicative of high permeability conditions. A comparison of the normalized, high- and low-stress slug-test responses indicates essentially identical behavior, which suggests that the well had been fully developed. Examination of the individual slug-test responses also indicates a nonlinear (concave downward), critically damped slug test response. Slug tests exhibiting this type of response behavior cannot be analyzed quantitatively with the standard, linear-response based analytical methods (i.e., using either the Bouwer and Rice - Section 3.1.1 or type-curve -Section 3.1.2). The High-K analysis method presented in Butler and Garnett (2000) (see Section 3.1.4) was used to analyze the slug tests at well 299-W10-28 that exhibit high permeability response characteristics. Because the test responses were nearly identical, results obtained from the High-K analysis method are quite comparable. Because of the rapid test recovery, selected low- and high-stress test responses were combined to facilitate the analysis process. Figure 4.2 shows the results of the combined analysis of selected low- and high-stress tests. Estimates for $\mathrm{K}$ ranged between 26.5 and $29.2 \mathrm{~m} /$ day, and averaged $27.9 \mathrm{~m}$ /day for all tests. 

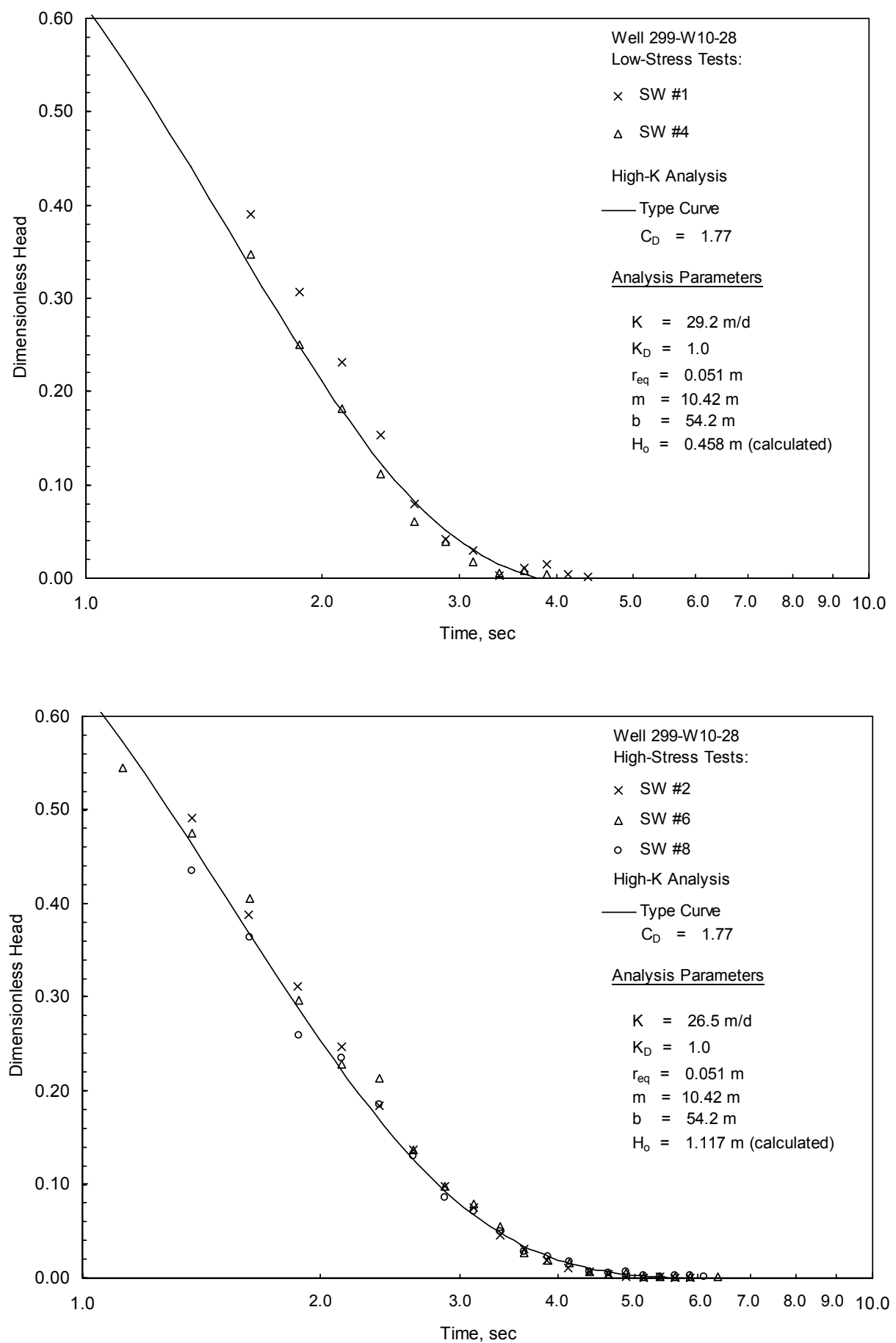

Figure 4.2. High-K Slug-Test Analysis Plots for Well 299-W10-28 [selected low-stress tests (top) and high-stress tests (bottom)] 


\subsection{Well 299-W14-14}

Well 299-W14-14 was previously slug tested shortly after construction in January 1999 and used as an observation well during a constant-rate pumping test of nearby well 299-W14-15 during August 2001. These test results are reported in Spane et al. (2001a and 2002), respectively. To support detailed hydrologic testing (i.e., tracer-dilution and tracer pumpback) in FY 2002, the well was retested on July 10, 2002 by slug testing (one high and one low stress) to assess whether any changes in the well/aquifer response characteristics had occurred.

During the $3 \frac{1}{2}$ years that occurred between slug testing, the surrounding water table had lowered causing a $1.75 \mathrm{~m}$ decrease in the saturated well-screen section. This represents approximately a $16 \%$ percent reduction in the well test interval. If it is assumed that hydraulic conductivity is uniform within the well-screen section, then a discernable shift (i.e., slower test recovery) in slug test response would be expected to be exhibited for the shorter well-screen tests. This is because slug test response is largely controlled by the test interval transmissivity (i.e., hydraulic conductivity multiplied by the saturated wellscreen length), as discussed in Section 3.1. For example, Figure 4.3 shows a comparison of predictive slug test type-curve responses for well 299-W14-14 with longer (10.67 m; January 1999) and shorter (8.92 m; July 2002) saturated, well-screen conditions, based on the average hydrologic properties previously reported in Spane et al. (2001a). As shown, a discernable delayed response (i.e., shift to the right) would be expected for slug tests conducted with the shorter saturated well-screen length.

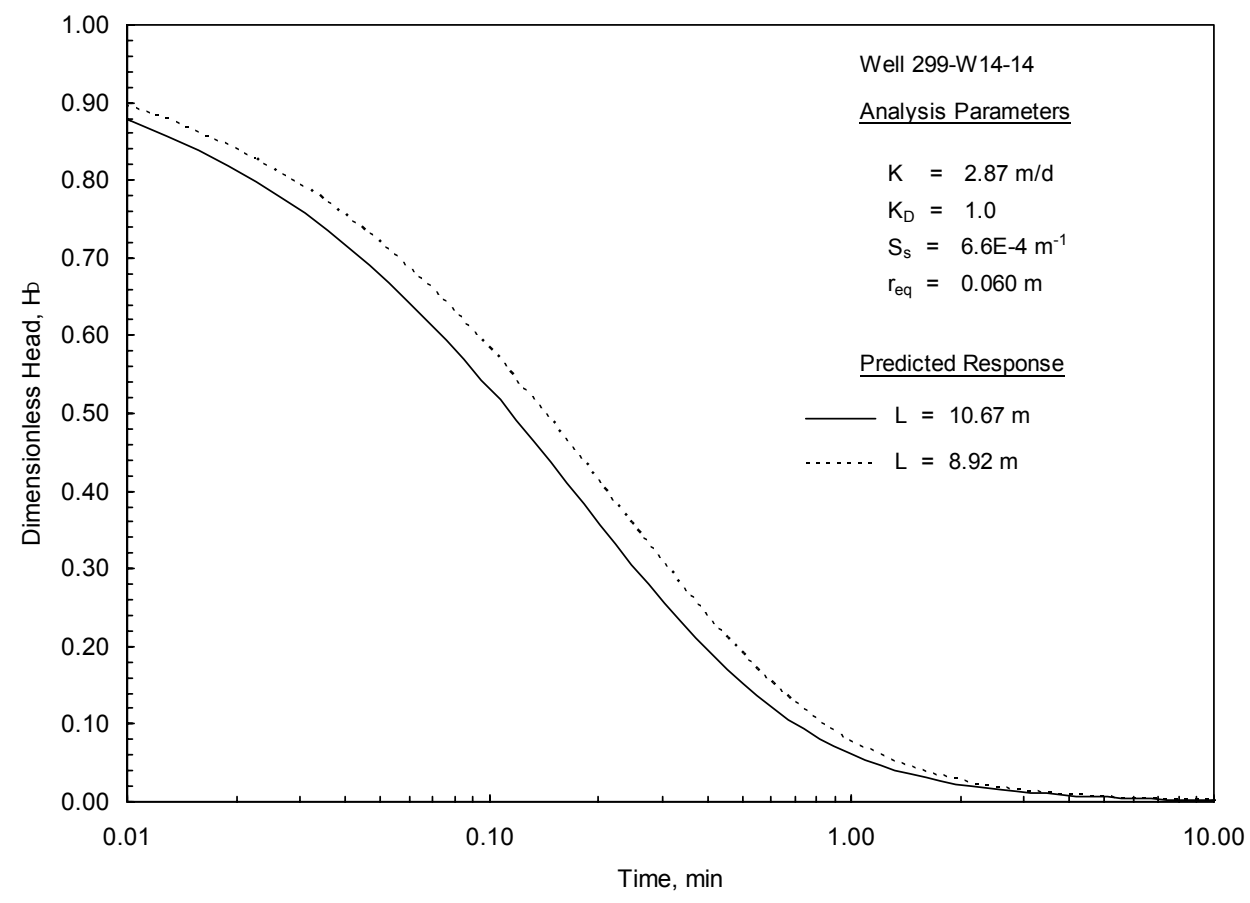

Figure 4.3. Predicted Slug-Test Type-Curve Response Plots for Well 299-W14-14 
Figure 4.4 shows a comparison of low stress slug tests conducted in January 1999 and July 2002. As shown, the recovery responses are very similar indicating a close correspondence in test interval transmissivity. This suggests that the upper $1.75 \mathrm{~m}$ of the $10.67 \mathrm{~m}$ saturated well-screen that was tested in January 1999 has a significantly lower hydraulic conductivity than the lower $8.92 \mathrm{~m}$ section. Average hydraulic conductivity estimates for slug tests conducted during July 2002 would be expected to be approximately $16 \%$ higher, therefore, to account for the shorter well-screen length.

A comparison of normalized July 2002 high- and low-stress slug-test responses indicates a slight delay in the early test-time response behavior for the high-stress test, which is attributable to higher turbulence that occurred during the early part of the test. For this reason, the low-stress test result is believed to provide more representative results. Examination of the individual slug-test responses also indicates an elastic (concave upward) response displayed on the Bouwer and Rice analysis plot in Figure 4.5. The elastic response requires that late-time analysis to be employed (i.e., the normalized head segment between 0.3 and 0.2) when using the Bouwer and Rice (1976) method, as recommended in Butler $(1996,1998)$. A comparison of K estimates indicates that slightly lower results ( $30 \%$ lower) were obtained for the Bouwer and Rice method. For the Bouwer and Rice method, estimates for K ranged between 2.26 and $2.35 \mathrm{~m} /$ day (average $2.31 \mathrm{~m} /$ day), while the type-curve method provided estimates between 3.02 and $3.41 \mathrm{~m} /$ day (average $3.22 \mathrm{~m} /$ day) for both stress-level tests. As expected, average hydraulic conductivity estimates for the July 2002 tests are approximately 15 to $20 \%$ higher than results reported in Spane et al. (2001a) for this well site location.

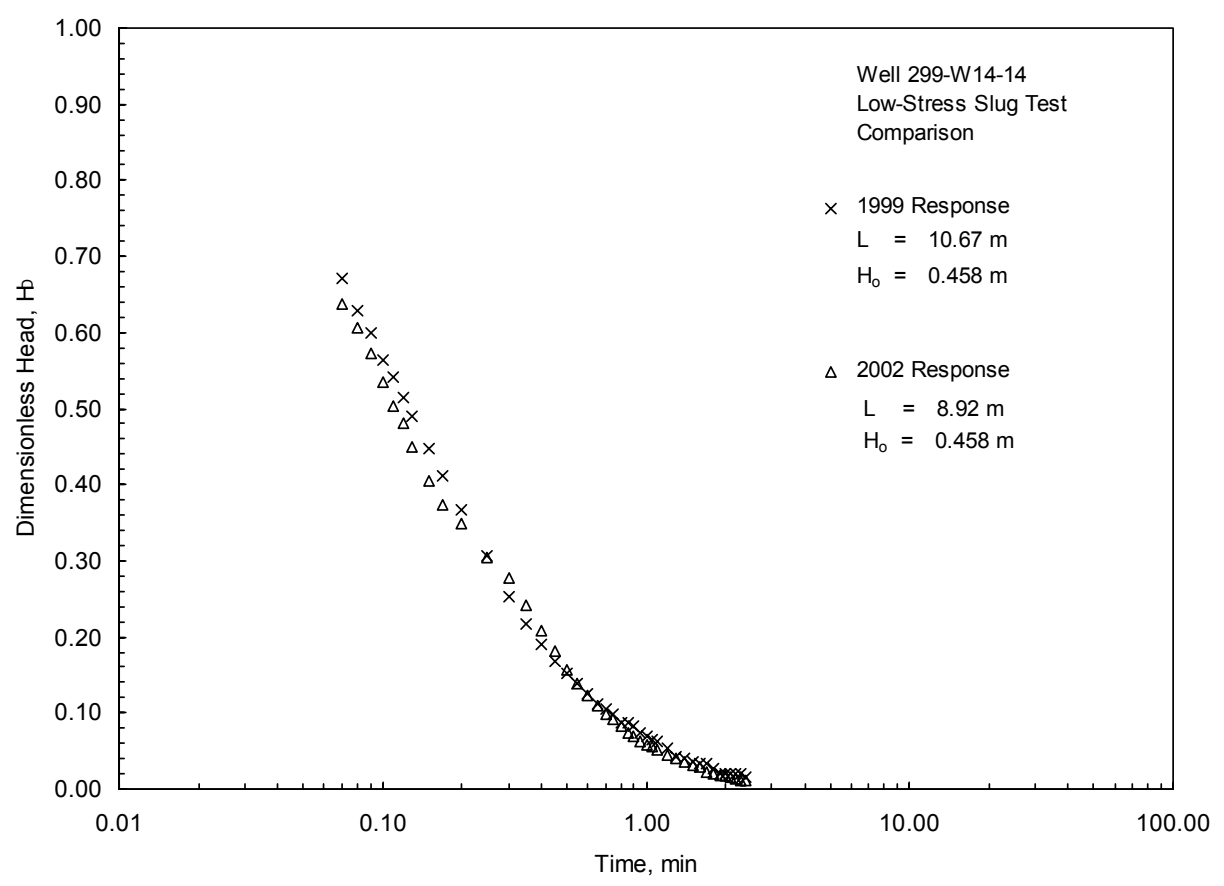

Figure 4.4. Comparison of Low-Stress, Slug-Test Response Plots for Well 299-W14-14 

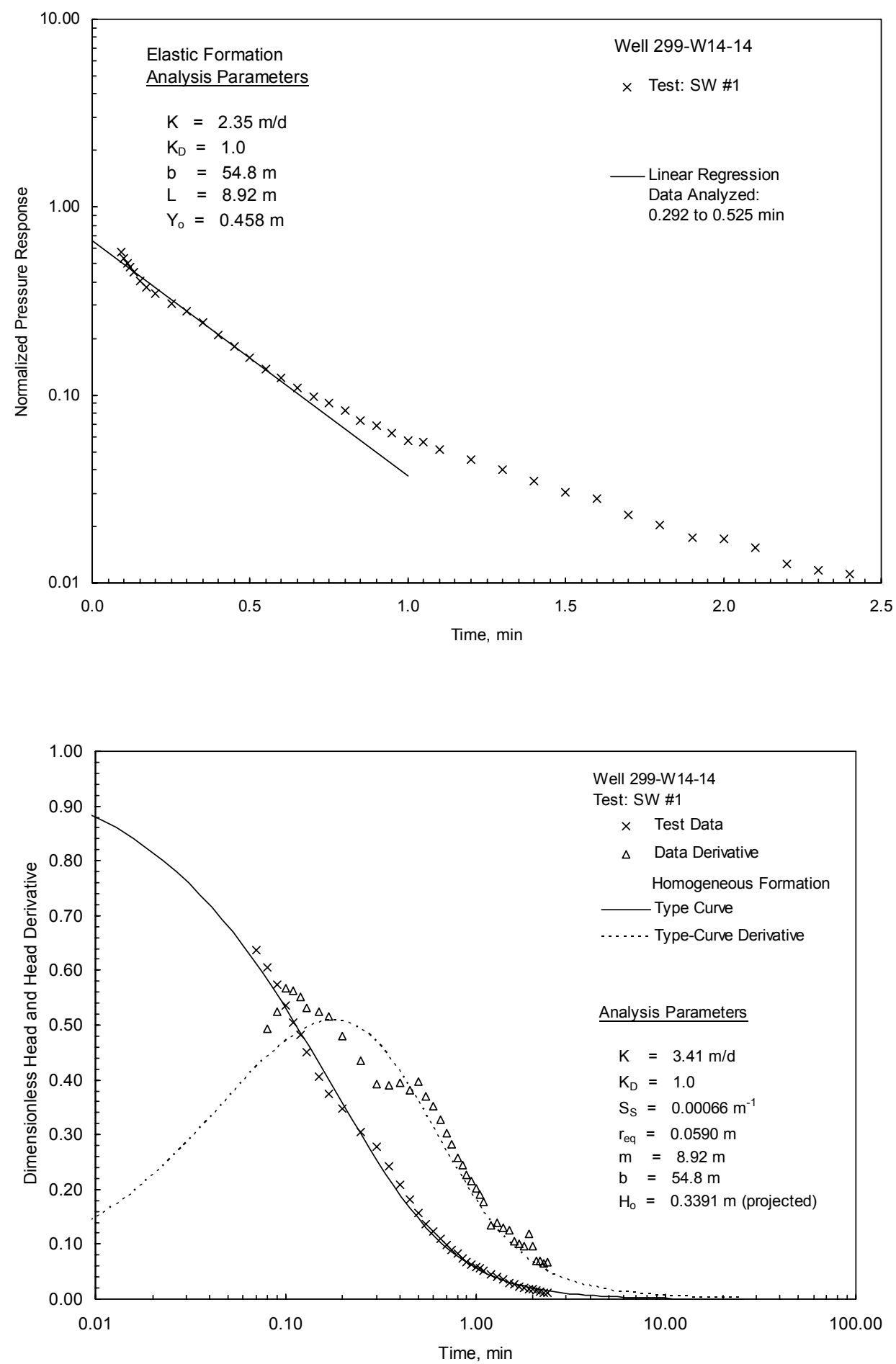

Figure 4.5. Selected Slug-Test Analysis Plots for Well 299-W14-14 [Bouwer and Rice method (top) and type-curve method (bottom)] 


\subsection{Well 299-W14-18}

A total of four slug tests (two high and two low stress) were conducted on December 12, 2001. All slug-test responses indicated a heterogeneous formation behavior, with a higher permeability zone located in proximity to the well screen, as indicated by a rapid recovery rate at early test times, which transitions to a slower recovery rate for the surrounding lower permeability material (exemplified on the type-curve response plot in Figure 4.6). A comparison of the normalized, high- and low-stress, slug-test responses indicates a slight delay in the early test-time response behavior for the high-stress tests, which is attributable to higher turbulence that occurred for these tests. For this reason, the low-stress test results are believed to provide more representative estimates. Nearly identical behavior was evident for tests conducted at a particular stress level, suggesting that the well had been developed sufficiently to establish stable skin conditions.

Slug tests exhibiting heterogeneous formation test response can be analyzed quantitatively using the homogeneous formation analysis approaches described in Chapter 3. For the homogeneous formation analysis, the type-curve method estimates for $\mathrm{K}$ ranged between 3.63 and $5.18 \mathrm{~m} /$ day (average $4.41 \mathrm{~m} /$ day) for both stress-level tests for the higher permeability inner zone (analysis figure not shown). For the outer lower permeability zone estimates of $\mathrm{K}$ ranged between 0.52 and $0.56 \mathrm{~m} /$ day (average $0.54 \mathrm{~m} /$ day). Results obtained from the Bouwer and Rice method are generally less definitive for tests exhibiting heterogeneous formation response behavior. However for these tests, the Bouwer and Rice

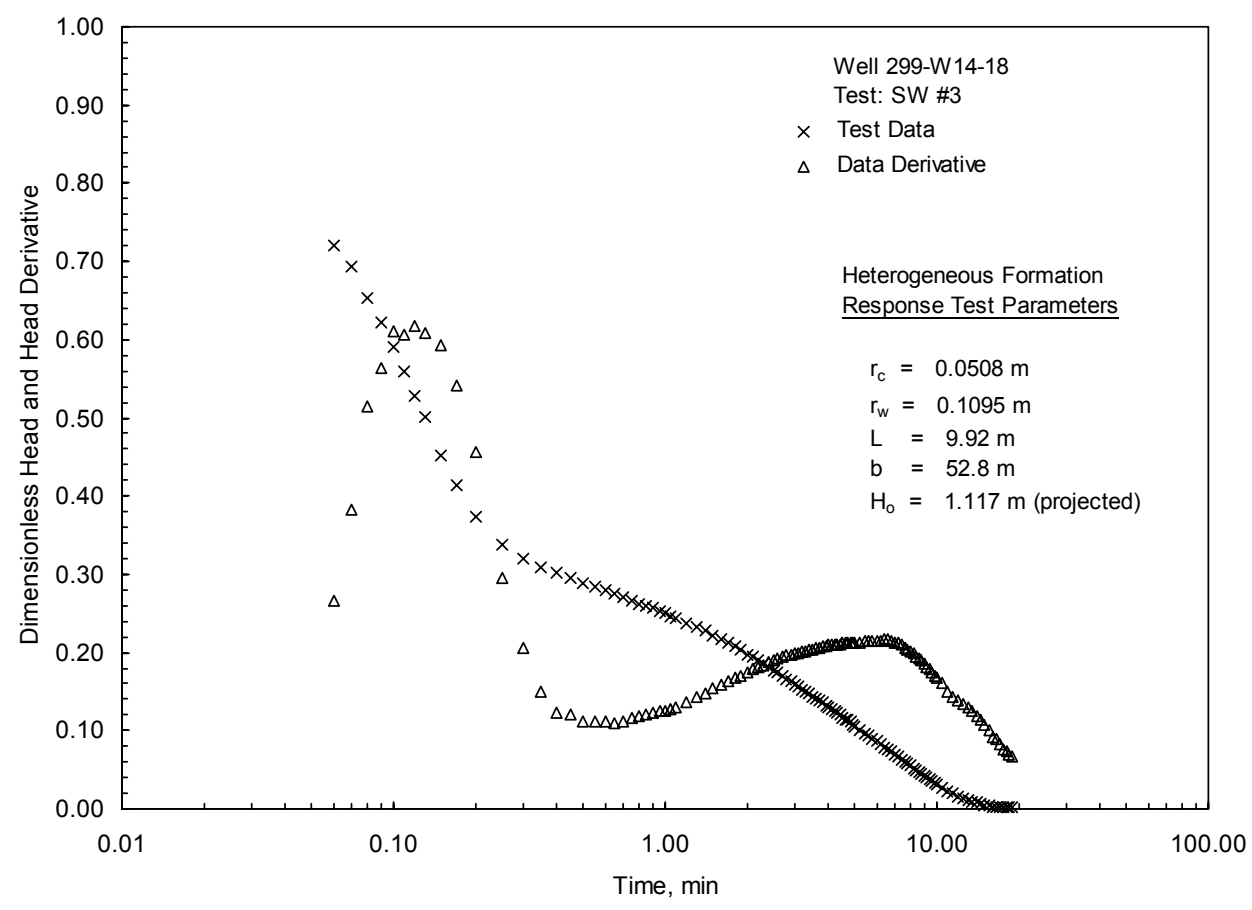

Figure 4.6. Heterogeneous Formation Slug-Test Response Exhibited for Well 299-W14-18 
method produced comparable $\mathrm{K}$ estimates as the type-curve method for the inner and outer permeability zones. For the Bouwer and Rice method estimates of $\mathrm{K}$ for the high permeability (inner) zone ranged between 2.95 and $4.22 \mathrm{~m} /$ day (average $3.59 \mathrm{~m} /$ day) for both stress-level tests. For the outer lower permeability zone, estimates of K ranged between 0.37 and $0.40 \mathrm{~m} /$ day (average $0.39 \mathrm{~m} /$ day). Selected examples of the analysis plots for this well are shown in Figure 4.7. As noted in Chapter 3, the inner zone results are believed to be not representative of actual in situ formation conditions and may be attributable to a number of artificially imposed conditions (e.g., over well-development, high permeability sandpack installation). For these reasons, only the outer zone analysis results should be used for assessing aquifer formation characteristics at this well location.

\subsection{Well 299-W22-84}

A total of four slug tests (two high and two low stress) were conducted on December 4, 2001. All slug-test responses indicated a heterogeneous formation behavior, with a higher permeability zone located in proximity to the well screen, as indicated by a rapid recovery rate at early test times, which transitions to a slower recovery rate for the surrounding lower permeability material (exemplified on the type-curve response plot in Figure 4.8). A comparison of the normalized, high- and low-stress, slug-test responses indicates a slight delay in the early test-time response behavior for the high-stress tests, which is attributable to higher turbulence that occurred for these tests. For this reason, the low-stress test results are believed to provide more representative estimates. Nearly identical behavior was evident for tests conducted at a particular stress level, suggesting that the well had been developed sufficiently to establish stable skin conditions.

Slug tests exhibiting heterogeneous formation test response can be analyzed quantitatively using the homogeneous formation analysis approaches described in Chapter 3. For the homogeneous formation analysis, the type-curve method estimates for $\mathrm{K}$ ranged between 4.54 and $6.35 \mathrm{~m} /$ day (average $5.45 \mathrm{~m} /$ day) for both stress-level tests for the higher permeability inner zone (analysis figure not shown). For the outer lower permeability zone estimates of K ranged between 1.38 and $1.64 \mathrm{~m} /$ day (average $1.51 \mathrm{~m} /$ day). Results obtained from the Bouwer and Rice method are generally less definitive for tests exhibiting heterogeneous formation response behavior. However for these tests, the Bouwer and Rice method produced comparable $\mathrm{K}$ estimates as the type-curve method for the inner and outer permeability zones. For the Bouwer and Rice method estimates of $\mathrm{K}$ for the high permeability (inner) zone ranged between 3.57 and $5.39 \mathrm{~m} /$ day (average $4.48 \mathrm{~m} /$ day) for both stress-level tests. For the outer lower permeability zone, estimates of $\mathrm{K}$ ranged between 1.05 and $1.25 \mathrm{~m} /$ day (average $1.15 \mathrm{~m} /$ day). Selected examples of the analysis plots for this well are shown in Figure 4.9. As noted in Chapter 3, the inner zone results are believed to be not representative of actual in situ formation conditions and may be attributable to a number of artificially imposed conditions (e.g., over well-development, high permeability sandpack installation). For these reasons, only the outer zone analysis results should be used for assessing aquifer formation characteristics at this well location. 

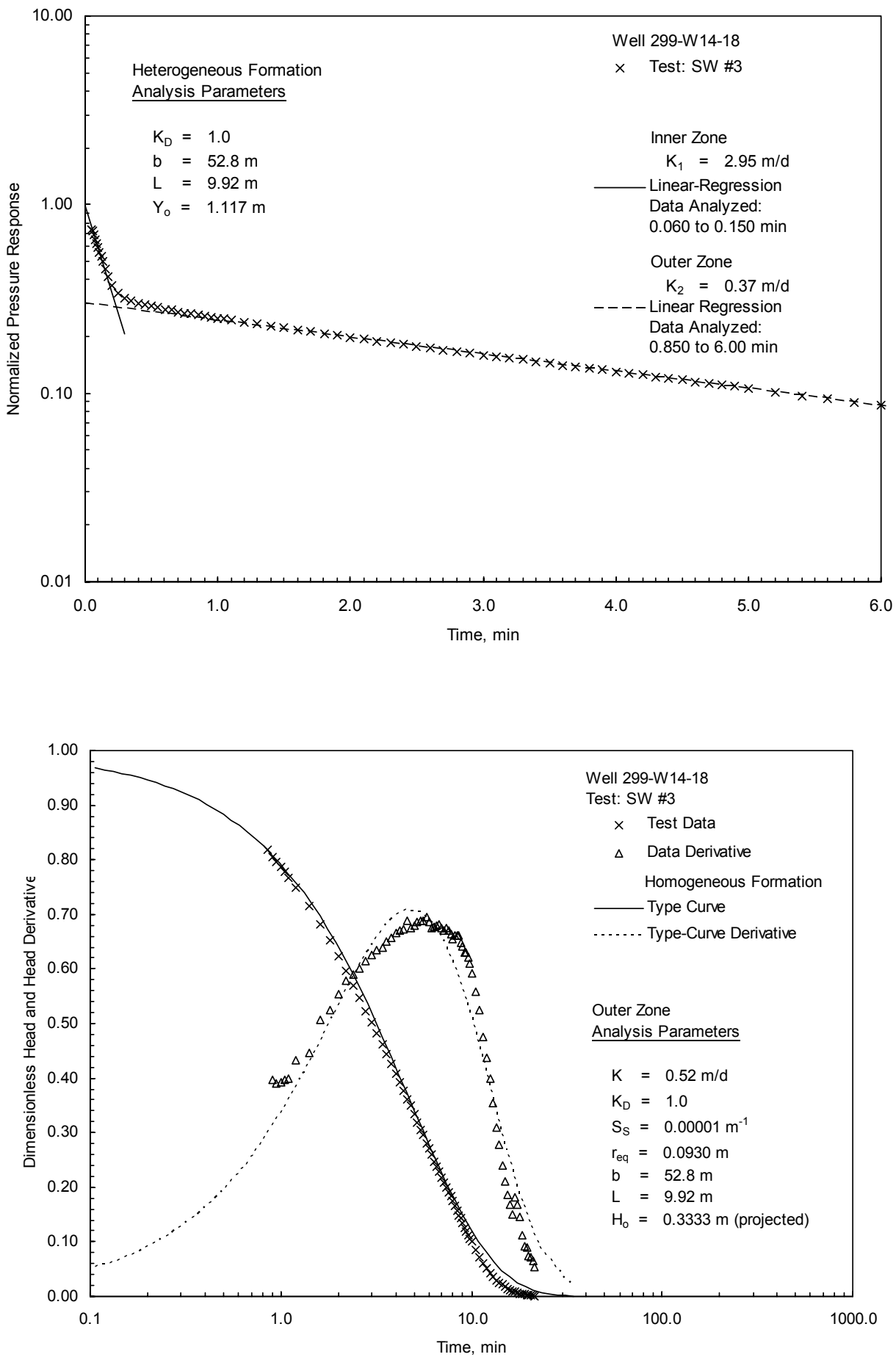

Figure 4.7. Selected Slug-Test Analysis Plots for Well 299-W14-18 [Bouwer and Rice method (top) and type-curve method (bottom)] 


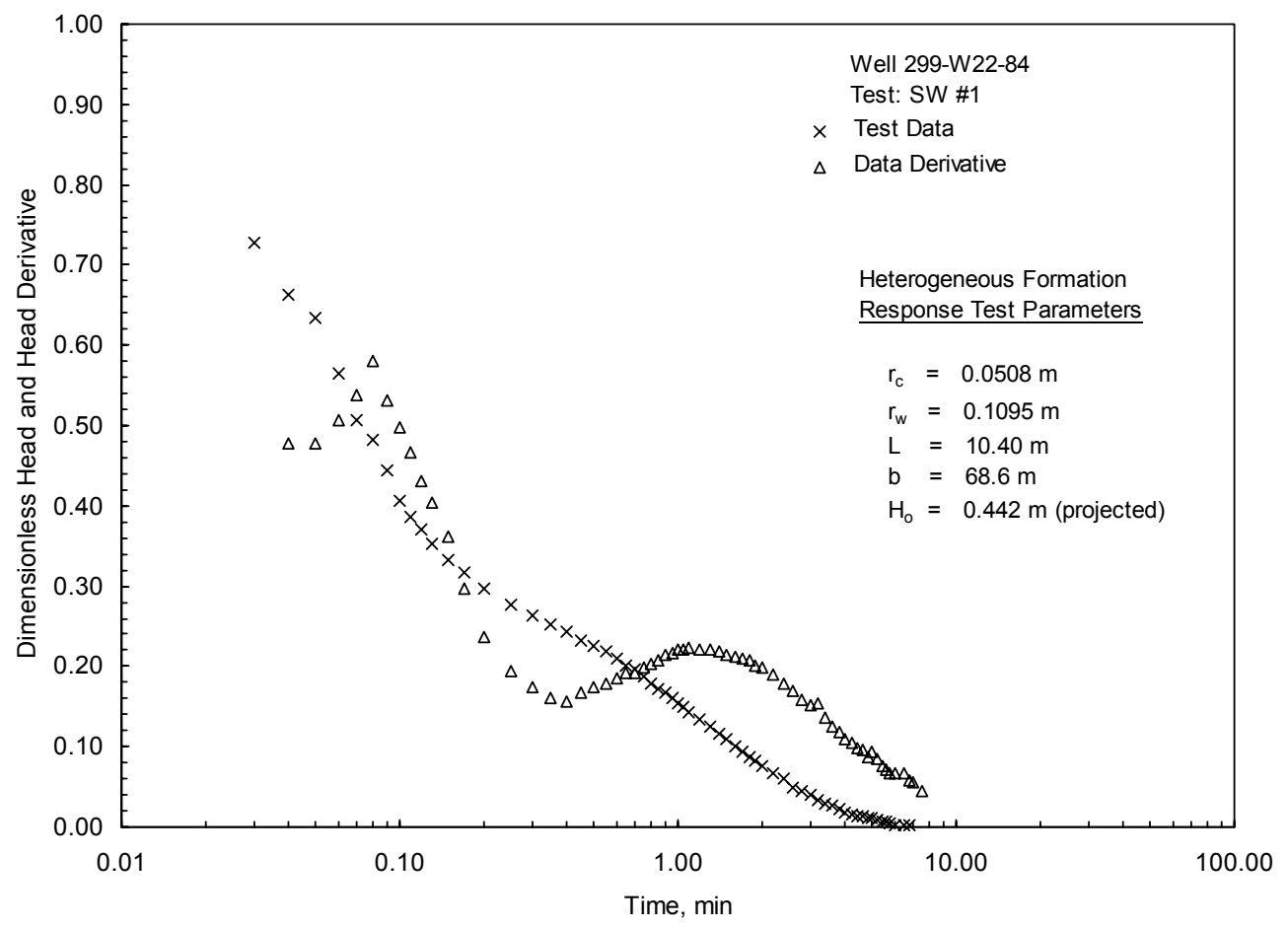

Figure 4.8. Heterogeneous Formation Slug-Test Response Exhibited for Well 299-W22-84

\subsection{Well 299-W22-85}

A total of four slug tests (two high and two low stress) were conducted on December 5, 2001. All slug-test responses indicated a heterogeneous formation behavior, with a very high permeability zone located in proximity to the well screen, as indicated by a rapid recovery rate at early test times ( $90 \%$ recovery within $\sim 5$ seconds), which transitions to a slower recovery rate for the surrounding lower permeability material (exemplified on the Bouwer and Rice analysis plot shown in Figure 4.10). A comparison of the normalized, high- and low-stress, slug-test responses indicates a slight delay in the early test-time response behavior for the high-stress tests, which is attributable to higher turbulence that occurred for these tests. For this reason, the low-stress test results are believed to provide more representative estimates. Nearly identical behavior was evident for tests conducted at a particular stress level, suggesting that the well had been developed sufficiently to establish stable skin conditions.

Slug tests exhibiting heterogeneous formation test response can be analyzed quantitatively using the homogeneous formation analysis approaches described in Chapter 3. For the homogeneous formation analysis, the type-curve method estimates for $\mathrm{K}$ ranged between 23.3 and $36.3 \mathrm{~m} /$ day (average $29.8 \mathrm{~m} /$ day) for both stress-level tests for the higher permeability inner zone (analysis figure not shown). For the outer lower permeability zone estimates of K ranged between 5.96 and $9.50 \mathrm{~m}$ /day (average $7.73 \mathrm{~m} /$ day). Results obtained from the Bouwer and Rice method are generally less definitive for tests exhibiting heterogeneous formation response behavior. However for these tests, the Bouwer and Rice 

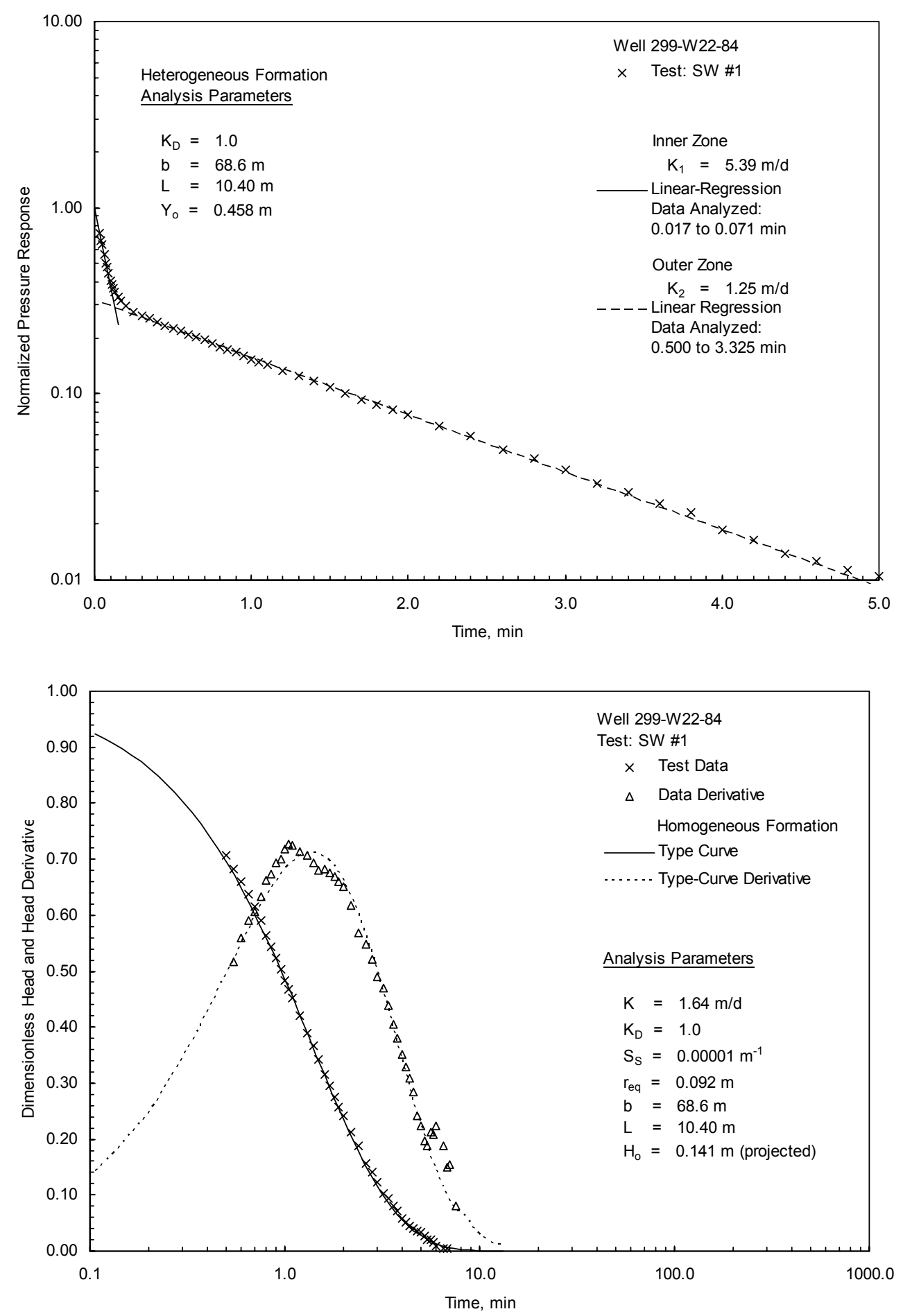

Figure 4.9. Selected Slug-Test Analysis Plots for Well 299-W22-84 [Bouwer and Rice method(top) and type-curve method (bottom)] 
method produced comparable $\mathrm{K}$ estimates as the type-curve method for the inner and outer permeability zones. For the Bouwer and Rice method estimates of $\mathrm{K}$ for the high permeability (inner) zone ranged between 21.3 and $30.1 \mathrm{~m} /$ day (average $25.7 \mathrm{~m} /$ day) for both stress-level tests. For the outer lower permeability zone, estimates of K ranged between 4.51 and $6.87 \mathrm{~m} /$ day (average $5.69 \mathrm{~m} /$ day). Selected examples of the analysis plots for this well are shown in Figure 4.10. As noted in Chapter 3, the inner zone results are believed to be not representative of actual in situ formation conditions and may be attributable to a number of artificially imposed conditions (e.g., over well-development, high permeability sandpack installation). For these reasons, only the outer zone analysis results should be used for assessing aquifer formation characteristics at this well location.

\subsection{Well 299-E33-338}

A total of six slug tests (three high and three low stress) were conducted on October 22, 2001. Very rapid recoveries ( $90 \%$ recovery within $\sim 2$ seconds) were exhibited for all tests, and are indicative of extremely high permeability conditions. A comparison of the normalized, high-stress slug-test responses indicates essentially identical behavior, which suggests that the well had been fully developed. Examination of the individual slug-test responses also indicates a nonlinear (concave downward), critically damped slug test response. Slug tests exhibiting this type of response behavior cannot be analyzed quantitatively with standard, linear-response based analytical methods (i.e., using either the Bouwer and Rice - Section 3.1.1 or type-curve -Section 3.1.2). The High-K analysis method presented in Butler and Garnett (2000) (see Section 3.1.4) was used to analyze the slug tests at well 299-E33-338 that exhibit high permeability response characteristics. Due to the relatively small test responses exhibited for low-stress test results, only test data obtained for high-stress tests were subjected to quantitative analysis. Because the high-stress test responses were nearly identical, analysis results would be expected to be quite comparable. Selected high-stress test responses were combined to facilitate the analysis process. Figure 4.11 shows the results of a composite analysis of two combined high-stress tests. As indicated, the $\mathrm{K}$ estimate obtained was $89 \mathrm{~m} /$ day. Identical values for $\mathrm{K}$ were essentially obtained for other high-stress test combinations. It should be noted that the $\mathrm{K}$ estimate obtained for this well site is near the upper limit analyzable with slug test methodology, for the given well-screen length characteristics (i.e., $\sim 100 \mathrm{~m} /$ day) A level of uncertainty (e.g. $\pm 20 \%$ ), therefore, is assigned to this characterization result. 

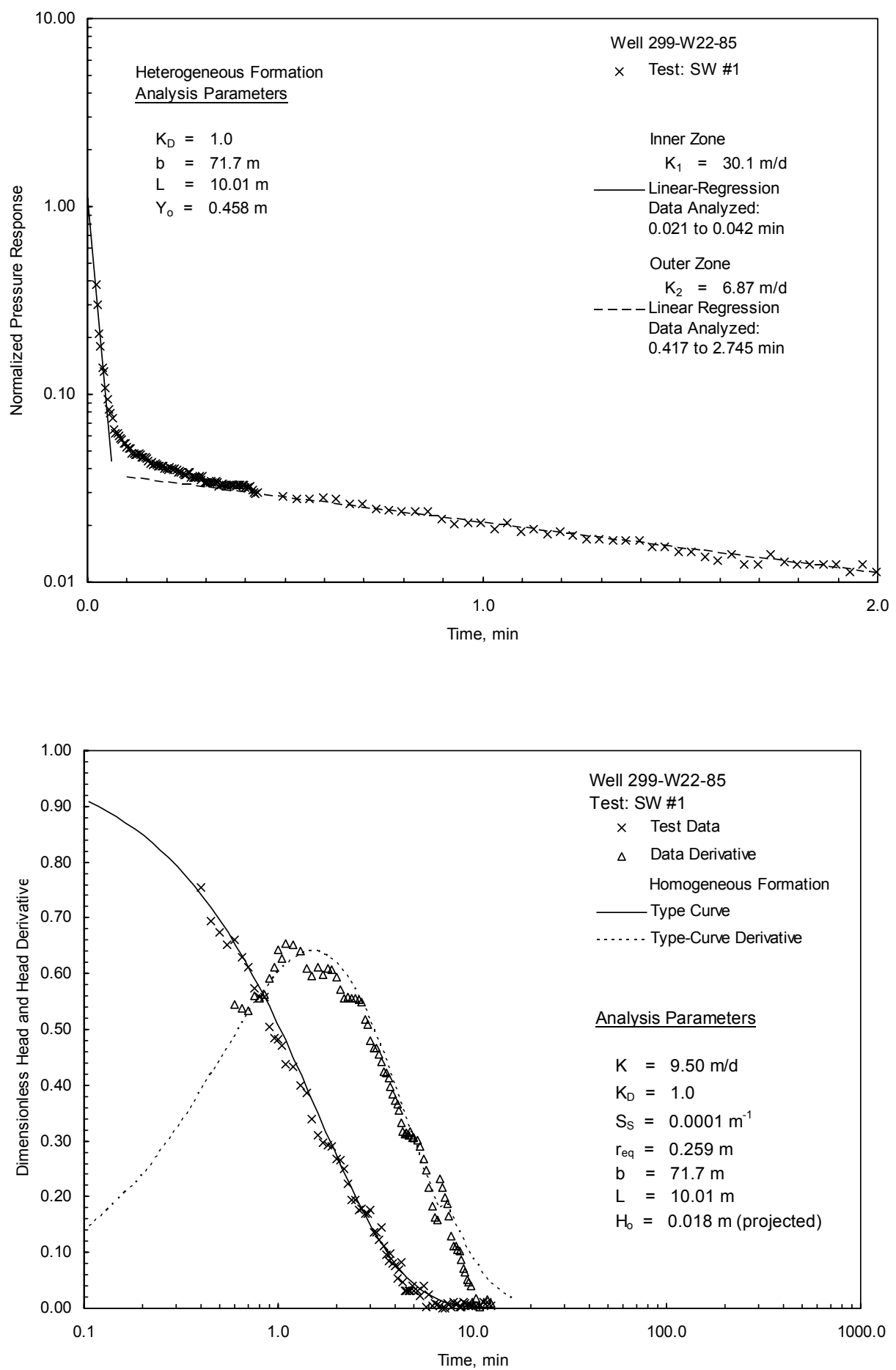

Figure 4.10. Selected Slug-Test Analysis Plots for Well 299-W22-85 [Bouwer and Rice method (top) and type-curve method (bottom)] 


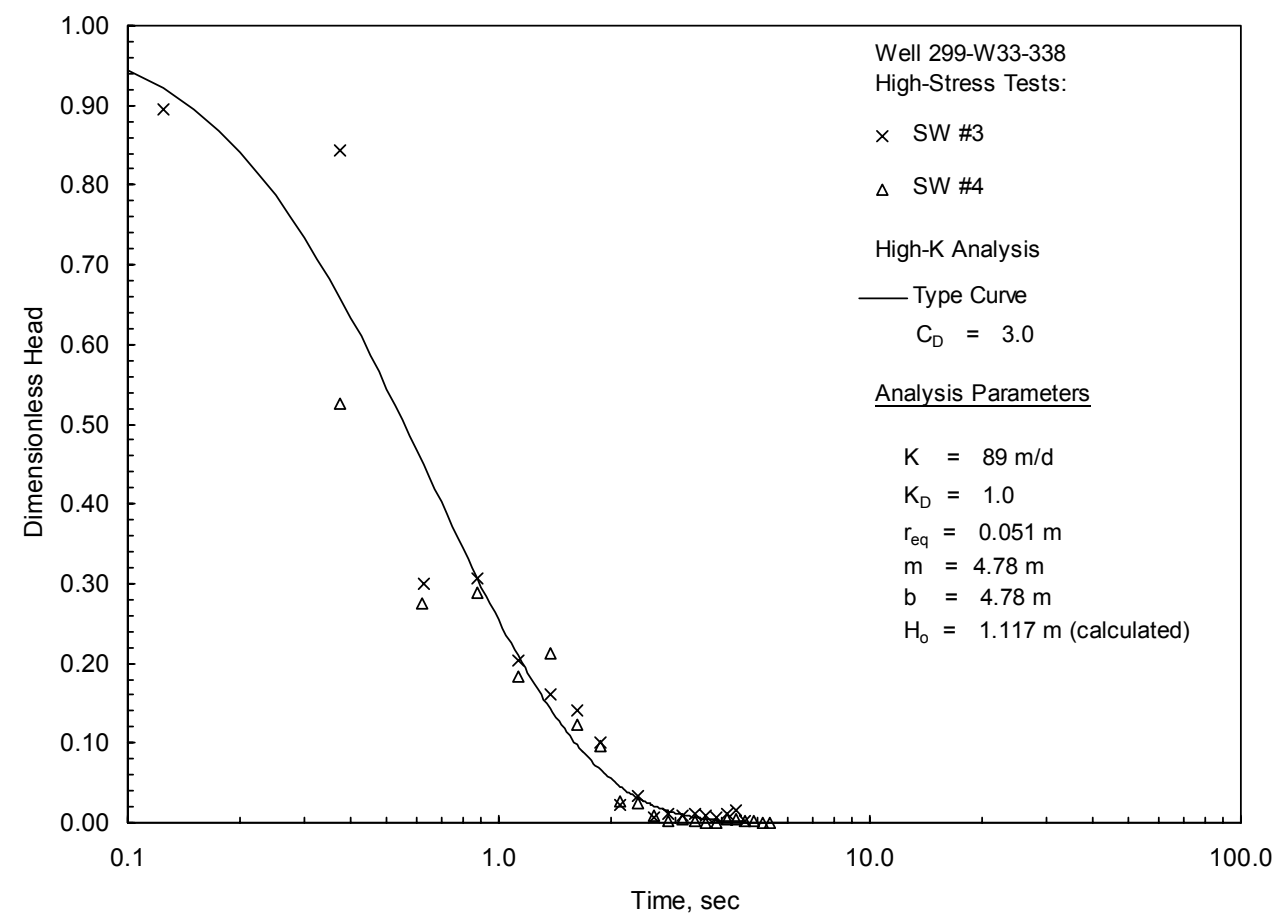

Figure 4.11. High-K Slug-Test Analysis Plot for Well 299-E33-338 


\subsection{Tracer-Dilution Test Results}

Wells 299-W14-14 and 299-W22-84 were selected for detailed tracer test characterization during FY 2002. Results from the tracer-dilution phase of the single-well tracer testing were analyzed using the methods described in Section 3.2.1. To be strictly valid, the analytical assumptions require that the dilution occurs only as the result of lateral groundwater inflow (i.e., no vertical groundwater flow). Only the tracer-dilution test conducted at well 299-W14-14 exhibited evidence of vertical flow conditions within the lower-section of the well-screen. In previous years, tracer-dilution patterns indicative of vertical flow conditions (see Section 3.2.3) were corroborated by separate in-well vertical flow tracer tests and/or electromagnetic flow meter surveys conducted within the wells, as reported in Spane et al. (2001a, 2001b). As during FY 2001, no independent corroboration of in-well vertical flow conditions at well 299-W14-14 was possible in FY 2002 using either of these two techniques due to budgetary constraints. For well 299-W14-14 which exhibits in-well vertical flow conditions within the lower well-screen section, a calculation of the average lateral $\mathrm{v}_{\mathrm{w}}$ was attempted by averaging the dilution depth data within the well-screen section. The estimate for this well, however, may be suspect (due to vertical flow conditions) and, therefore, should only be used for qualitative comparison purposes. A description of the performance and analysis of the tracer-dilution tests conducted in the two wells tested using the tracerdilution characterization method is provided in the following sections.

\subsection{Well 299-W14-14}

A single well tracer-dilution test was initiated on July 12, 2002 (1015 hour, PDT) by administering 4.54 liters of tracer solution (containing 13.15 grams of bromide) within the $8.92 \mathrm{~m}$ saturated wellscreen section (67.89 to $76.81 \mathrm{~m}$ below brass cap). The tracer was introduced into the well using a 2.54 centimeter diameter polypropylene tube that was open at a depth setting of $76.49 \mathrm{~m}$ below brass cap. Following tracer introduction, an equilibration time of approximately 14 minutes was observed to allow for dissipation of the displaced non-tracer water, originally within the 2.54 centimeter tracer tube, into the surrounding well-screen column. After the 14 minute equilibration period, the tracer tube was slowly raised out of the well water column, causing emplacement of the 4.54 liters of prepared tracer into the well water column. The tracer tube then was lowered slowly and raised two times within the water column over a 5 minute period to mix the tracer within the well-screen section. As noted in Spane et al. (2001b, 2002), this method of tracer mixing provides a low-stress means of dispersing the administered tracer within the well-screen section. The designed bromide concentration within the well screen following mixing of the added tracer was $\sim 175 \mathrm{mg} /$ liter.

Following mixing of the tracer solution, an assembly of five bromide probe sensors spaced individually at a separation distance of $1.8 \mathrm{~m}$ was lowered into the well. Final depth settings for the five bromide probes were 76.75, 74.95, 73.15, 71.35, and $69.55 \mathrm{~m}$ below brass cap. Each probe had an attached plastic centralizer to keep the probe approximately centered within the well-screen section. Installation of the probe assembly was completed in approximately 30 minutes following the mixing of the tracer within the

well screen. The bromide concentration within the borehole following emplacement and equilibration of the probes (i.e., after 60 minutes following initial mixing) was approximately $155 \mathrm{mg} /$ liter, and ranged 
between 112 to $182 \mathrm{mg} /$ liter for the various probe depth settings. The average initial bromide concentration within the well screen $\left(\mathrm{C}_{\mathrm{o}}\right)$, based on back-projection of the fitted-linear regression concentration response to time $=0$, was $173 \mathrm{mg} /$ liter. The dilution and dissipation of bromide tracer within the well screen was observed for a period of 8,625 minutes (5.99 days). At the end of the test, the projected average bromide tracer concentration was $3.72 \mathrm{mg} /$ liter within the well-screen section.

Visual examination of the dilution patterns for the various sensor-depth settings indicates a slight, vertical, downward flow condition within the well-screen section between the bottom two probe depth settings, i.e., between 74.95 to $76.75 \mathrm{~m}$ below brass cap (see Section 8.1). A downward, in-well average flow velocity of 0.0056 meter per minute, was calculated by using the arrival times of recognizable tracer signature between the two tracer sensors.

As discussed in Section 3.2.1, to be strictly valid, tracer-dilution tests require that no vertical flow conditions exist within the well and that the tracer is continually mixed within the test section. To "simulate" a continuously mixed condition, an average well-screen tracer concentration was calculated, based on averaging all five sensor-depth readings recorded with time (i.e., 69.55 to $76.75 \mathrm{~m}$ below brass cap). It is not known whether the vertical flow conditions observed within the well are significant enough to affect adversely the results of the tracer-dilution test. The analysis results, therefore, should be viewed as being qualitative estimates.

The observed, average dilution pattern versus time can be analyzed to calculate $\mathrm{v}_{\mathrm{w}}$, using Equation 3.3. Linear-regression analysis of the average dilution response (shown in Figure 5.1) within the well screen $\left(r^{2}=0.99\right)$ indicates a slope on the natural log of concentration versus time of -0.000381 minutes $^{-1}$. The calculated average A/V relationship for the test interval, taking into account the presence of sensor instrumentation/cable test system cross-sectional area, is $13.505 \mathrm{~m}^{-1}$. Based on these observed and measured parameters, an average calculated $\mathrm{v}_{\mathrm{w}}$ is $0.041 \mathrm{~m} /$ day.

If lateral groundwater-flow conditions occur throughout the entire well, then a comparison of the calculated well velocities at the various sensor-depth settings can provide an assessment of the vertical profile of horizontal permeability within the well-screen section. A comparison of the average well-flow velocities at the top three individual sensor-depth settings indicates very uniform low, in-well flow velocities which only vary by $0.003 \mathrm{~m} /$ day within the well-screen section (range: 0.037 to $0.040 \mathrm{~m} / \mathrm{day}$ ). If it can be assumed that a direct correlation between well-flow velocity and aquifer permeability exists for the well/aquifer site, then permeabilities do not vary by more than $10 \%$ within the upper $\sim 5 \mathrm{~m}$ section of the well screen. Table 5.1 summarizes results from the tracer-dilution test at well 299-W14-14.

\subsection{Well 299-W22-84}

A single-well tracer-dilution test, was initiated on August 14, 2002 (1010 hours, PDT) by administering 5.50 liter of tracer solution (containing 16.43 grams of bromide) within the $10.22 \mathrm{~m}$ saturated well-screen section ( 71.16 to $81.38 \mathrm{~m}$ below brass cap). The tracer was introduced into the well using a 2.54 centimeter diameter polypropylene tube that was open at a depth setting of $81.24 \mathrm{~m}$ below brass cap. Following tracer introduction, an equilibration time of approximately 13 minutes was observed to allow for dissipation of the displaced non-tracer water originally within the 2.54 centimeter tracer tube 


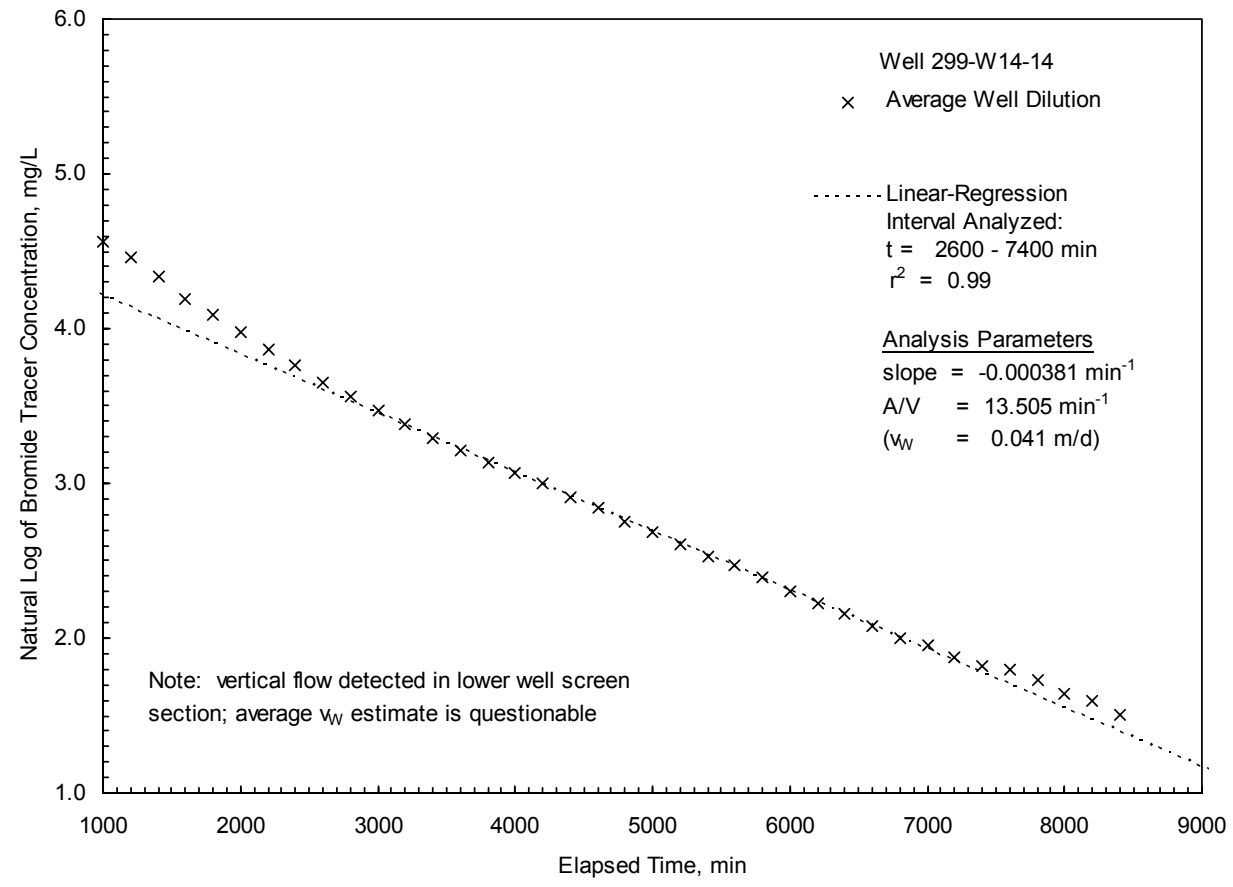

Figure 5.1. Average Tracer-Dilution Test Results Within 299-W14-14

Table 5.1. Tracer-Dilution Test Results for Well 299-W14-14

\begin{tabular}{|c|c|c|c|c|c|}
\hline $\begin{array}{l}\text { Well Sensor/ } \\
\text { Depth Setting, m, } \\
\text { below brass cap }\end{array}$ & $\begin{array}{c}\text { Tracer } \\
\text { Concentration/ } \\
\text { Dilution Slope, } \mathrm{d}(\ln \\
\text { C) dt }\left(\text { minute }^{-1}\right)\end{array}$ & $\begin{array}{c}\text { Linear- } \\
\text { Regression } \\
\text { Correlation } \\
\text { Coefficient, } \mathrm{r}^{2}\end{array}$ & $\begin{array}{c}\text { Projected Initial } \\
\text { Tracer } \\
\text { Concentration, } \\
\mathrm{C}_{\mathrm{o}}(\mathrm{mg} / \mathrm{liter})\end{array}$ & $\begin{array}{c}\text { Well } \\
\text { Measurement } \\
\text { Area/Volume } \\
\text { Ratio, A/V }\left(\mathrm{m}^{-1}\right)\end{array}$ & $\begin{array}{l}\text { Calculated Well- } \\
\text { Screen Flow } \\
\text { Velocity, } \mathrm{v}_{\mathrm{w}} \\
\text { (m/day) }\end{array}$ \\
\hline 69.55 & -0.000353 & 0.99 & 189 & 13.650 & 0.037 \\
\hline 71.35 & -0.000375 & 0.99 & 181 & 13.577 & 0.040 \\
\hline 73.15 & -0.000367 & 0.99 & 160 & 13.505 & 0.039 \\
\hline $74.95^{(\mathrm{a})}$ & - & - & - & 13.435 & - \\
\hline $76.75^{(\mathrm{a})}$ & - & - & - & 13.364 & - \\
\hline Average $^{(b)}$ & -0.000381 & 0.99 & 173 & 13.505 & 0.041 \\
\hline $\begin{array}{l}\text { (a) Vertica } \\
\text { (b) Detern }\end{array}$ & $\mathrm{n}$ analysis & & & & \\
\hline
\end{tabular}


into the surrounding well-screen column. After the 13 minute equilibration period, the tracer tube was slowly raised out of the well water column, causing emplacement of the 5.50 liters of prepared tracer into the well water column. The tracer tube then was lowered slowly and raised two times within the water column over a 5 minute period to mix the tracer within the well-screen section. As noted in Spane et al. (2001b, 2002), this method of tracer mixing provides a low-stress means of dispersing the administered tracer within the well-screen section. The designed bromide concentration within the well screen following mixing of the added tracer was $\sim 200 \mathrm{mg} /$ liter.

Following mixing of the tracer solution, an assembly of five bromide probe sensors spaced individually at a separation distance of $1.8 \mathrm{~m}$ was lowered into the well. Final depth settings for the five bromide probes were 80.4, 78.6, 76.8, 75.0, and $73.2 \mathrm{~m}$ below brass cap. Each probe had an attached plastic centralizer to keep the probe approximately centered within the well-screen section. Installation of the probe assembly was completed in approximately 25 minutes following the mixing of the tracer within the well screen. The bromide concentration within the borehole following emplacement and equilibration of the probes (i.e., after 60 minutes following initial mixing) was approximately $166 \mathrm{mg} / \mathrm{liter}$, and ranged between 133 to $197 \mathrm{mg} /$ liter for the various probe depth settings. The average initial bromide concentration within the well screen $\left(\mathrm{C}_{\mathrm{o}}\right)$, based on back-projection of the fitted-linear regression concentration response to time $=0$, was $196 \mathrm{mg} /$ liter. The dilution and dissipation of bromide tracer within the well screen was observed for a period of 7,190 minutes (4.99 days). At the end of the test, the projected average bromide tracer concentration was $0.90 \mathrm{mg} /$ liter within the well-screen section.

Visual examination of the dilution patterns for the various sensor-depth settings indicates no significant vertical flow conditions within the well-screen section. The natural log of concentration versus time depth-setting plots generally exhibit linear relationships for all sensor depth locations over most the dilution time period (i.e., 7,190 minutes [4.99 days]). The estimated average lateral, in-well flow velocity within the entire well-screen section was analyzed to calculate $\mathrm{v}_{\mathrm{w}}$, using Equation 3.3. Linear-regression analysis of the average dilution response (shown in Figure 5.2) for the five sensor-depth settings within the well screen $\left(r^{2}=0.99\right)$ indicates a slope on the natural log of concentration versus time of -0.000840 minutes $^{-1}$. The calculated average A/V relationship for the test interval, taking into account the presence of sensor instrumentation/cable test system cross-sectional area, is $13.505 \mathrm{~m}^{-1}$. Based on these observed and measured parameters, an average calculated $\mathrm{v}_{\mathrm{w}}$ is $0.090 \mathrm{~m} /$ day.

If lateral groundwater-flow conditions occur throughout the entire well, then a comparison of the calculated well velocities at the various sensor-depth settings can provide an assessment of the vertical profile of horizontal permeability within the well-screen section. A comparison of the average well-flow velocities at the five individual sensor-depth settings indicates relatively uniform low, in-well flow velocities which only vary by $0.018 \mathrm{~m} /$ day within the well-screen section (range: 0.076 to $0.094 \mathrm{~m} /$ day). If it can be assumed that a direct correlation between well-flow velocity and aquifer permeability exists for the well/aquifer site, then permeabilities do not vary by more than $20 \%$ within the well-screen section, with the lowest relative permeabilities (i.e., lower flow velocities) occurring within the upper section of the well-screen (i.e., 73.2 to $75.0 \mathrm{~m}$ below brass cap). Table 5.2 summarizes results from the tracerdilution test at well 299-W22-84. 


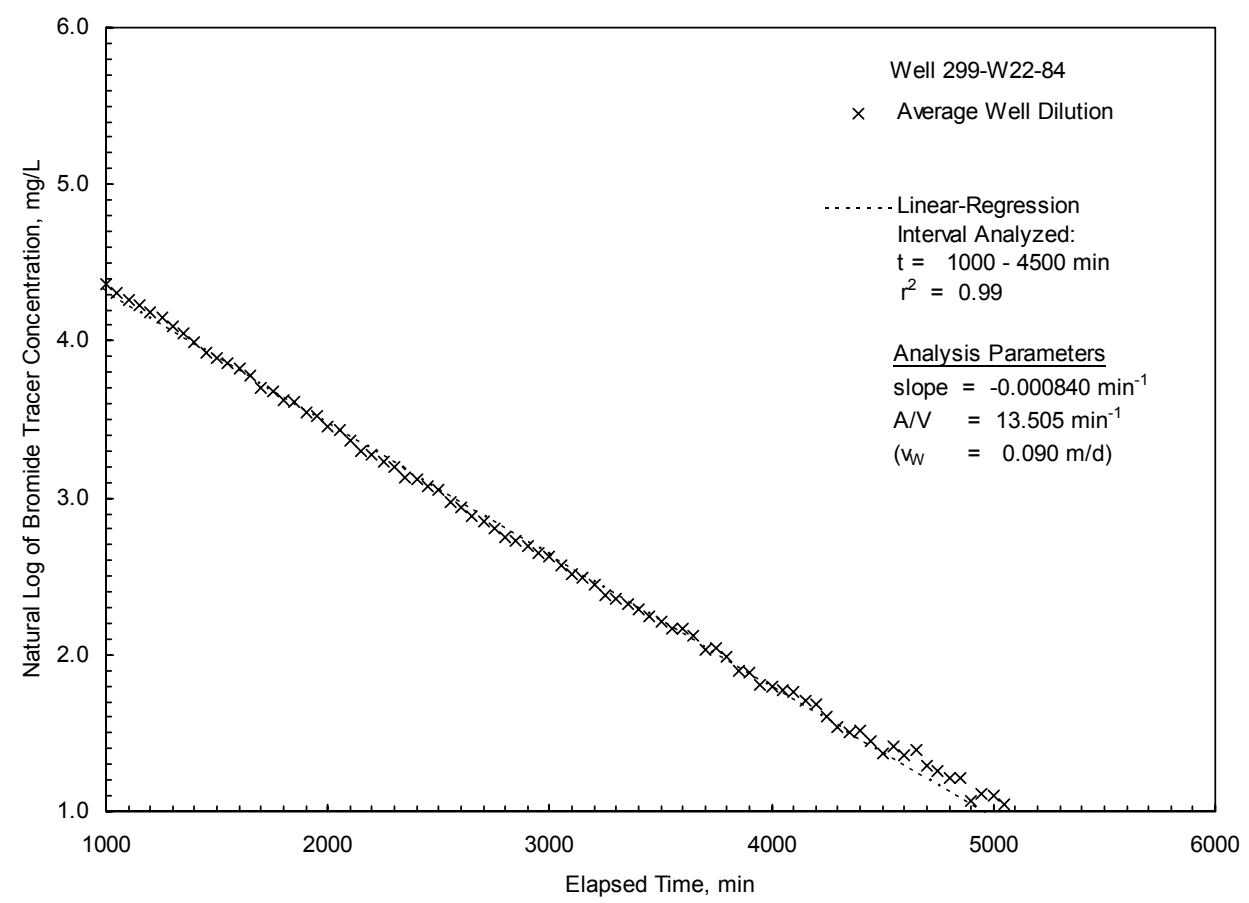

Figure 5.2. Average Tracer-Dilution Test Results Within Well 299-W22-84

Table 5.2. Tracer-Dilution Test Results for Well 299-W22-84

\begin{tabular}{|c|c|c|c|c|c|}
\hline $\begin{array}{l}\text { Well Sensor/ } \\
\text { Depth Setting, m, } \\
\text { below brass cap }\end{array}$ & $\begin{array}{c}\text { Tracer } \\
\text { Concentration/ } \\
\text { Dilution Slope, d (ln } \\
\text { C) dt }\left(\text { minute }^{-1}\right)\end{array}$ & $\begin{array}{c}\text { Linear- } \\
\text { Regression } \\
\text { Correlation } \\
\text { Coefficient, } \mathrm{r}^{2}\end{array}$ & $\begin{array}{c}\text { Projected Initial } \\
\text { Tracer } \\
\text { Concentration, } \\
\mathrm{C}_{\mathrm{o}}(\mathrm{mg} / \text { liter })\end{array}$ & $\begin{array}{c}\text { Well } \\
\text { Measurement } \\
\text { Area/Volume } \\
\text { Ratio, A/V }\left(\mathrm{m}^{-1}\right)\end{array}$ & $\begin{array}{l}\text { Calculated Well- } \\
\text { Screen Flow } \\
\text { Velocity, } \mathrm{v}_{\mathrm{w}} \\
\text { (m/day) }\end{array}$ \\
\hline 73.2 & -0.000725 & 0.99 & 208 & 13.650 & 0.076 \\
\hline 75.0 & -0.000750 & 0.99 & 162 & 13.577 & 0.079 \\
\hline 76.8 & -0.000840 & 0.99 & 161 & 13.505 & 0.090 \\
\hline 78.6 & -0.000874 & 0.99 & 141 & 13.435 & 0.094 \\
\hline 80.4 & -0.000852 & 0.99 & 127 & 13.364 & 0.092 \\
\hline Average $^{(a)}$ & -0.000840 & 0.99 & 196 & 13.505 & 0.090 \\
\hline
\end{tabular}




\subsection{Tracer-Pumpback Test Results}

Results from the bromide tracer-pumpback phase of the single-well tracer testing were analyzed using the methods described in Section 3.2.2. The analytical assumptions of full aquifer penetration and rapid pulse injection into the aquifer were not met with the given field test conditions. Because of these test deficiencies, the estimates derived from the pumpback test for effective porosity, $\mathrm{n}_{\mathrm{e}}$, and average groundwater-flow velocity within the aquifer, $\mathrm{v}_{\mathrm{a}}$, should be only used qualitatively. Future efforts will be directed to improve the estimates for $\mathrm{n}_{\mathrm{e}}$ and $\mathrm{v}_{\mathrm{a}}$ by accounting for these effects. A description of the information pertinent to the tracer-pumpback test performed in two wells is provided below.

\subsection{Well 299-W14-14}

After a 8,625 minute (5.99 day) tracer-drift period, $t_{d}$, recovery of the tracer from well 299-W14-14 and the surrounding aquifer was initiated with a constant-rate pumping test beginning on July 18, 2002 (1000 hours PDT). Tracer recovery was terminated after 210 minutes. The average tracer concentration within the well was 3.72 milligrams per liter at the beginning of pumpback, based on late-time projection of the average dilution regression line (Figure 5.1) to the time of tracer pumpback initiation. Given the calculated well screen and sandpack volumes of 72.64 and 61.45 liters, respectively, 12.76 grams of the 13.15 grams of tracer initially emplaced in the well, are estimated to have been transported within the aquifer. After minor flow adjustments were completed during the first 2 minutes of the test, pumping rates remained relatively constant during tracer pumpback, ranging between 37.55 and 39.46 liters $/ \mathrm{min}$ (average 38.72 liters/min) for the entire test as shown in Figure 6.1. An estimated 8.92 grams of the total 13.15 grams of tracer (i.e., $\sim 68 \%$ ) emplaced in the well were recovered during the constant-rate pumping test. The pumping time, $\mathrm{t}_{\mathrm{p}}$, to recover $50 \%$ of the tracer emplaced within the aquifer (accounting for transit time during pumping from the well screen to land surface) is estimated at 48.67 minutes. The time required to recover the center of the tracer mass that was transported within the aquifer was used in Equations 3.8 and 3.9 to calculate $\mathrm{n}_{\mathrm{e}}$ and $\mathrm{v}_{\mathrm{a}}$. As indicated in the equations, information pertaining to hydraulic conductivity, $\mathrm{K}$, hydraulic gradient, I, aquifer thickness, $\mathrm{b}$, and pumping rate, $\mathrm{Q}$, must also be known for the test well site.

A K value of $2.21 \mathrm{~m} /$ day was used, which is based on results from the constant-rate pumping test for the test well (i.e., during tracer pumpback; Section 7.1). The calculated local I value of $0.00112 \mathrm{~m} / \mathrm{m}$ was determined using trend-surface analysis for water-level elevation measurement periods from four nearby monitor wells (299-W14-13, 299-W14-15, 299-W14-16, and 299-W14-17) immediately prior to initiating tracer-dilution testing on July 12, 2002, and four days after termination of tracer pumpback on July 22, 2002 (Section 9.5). The I value is within the range of hydraulic gradients cited for Waste Management Area TX-TY, as reported in Spane et al. (2001 a, 2001b, 2002) and listed in Table A.2 of Hartman et al. (2002). The b value of $54.8 \mathrm{~m}$ was calculated directly from projection of known geologic relationships at nearby wells. 


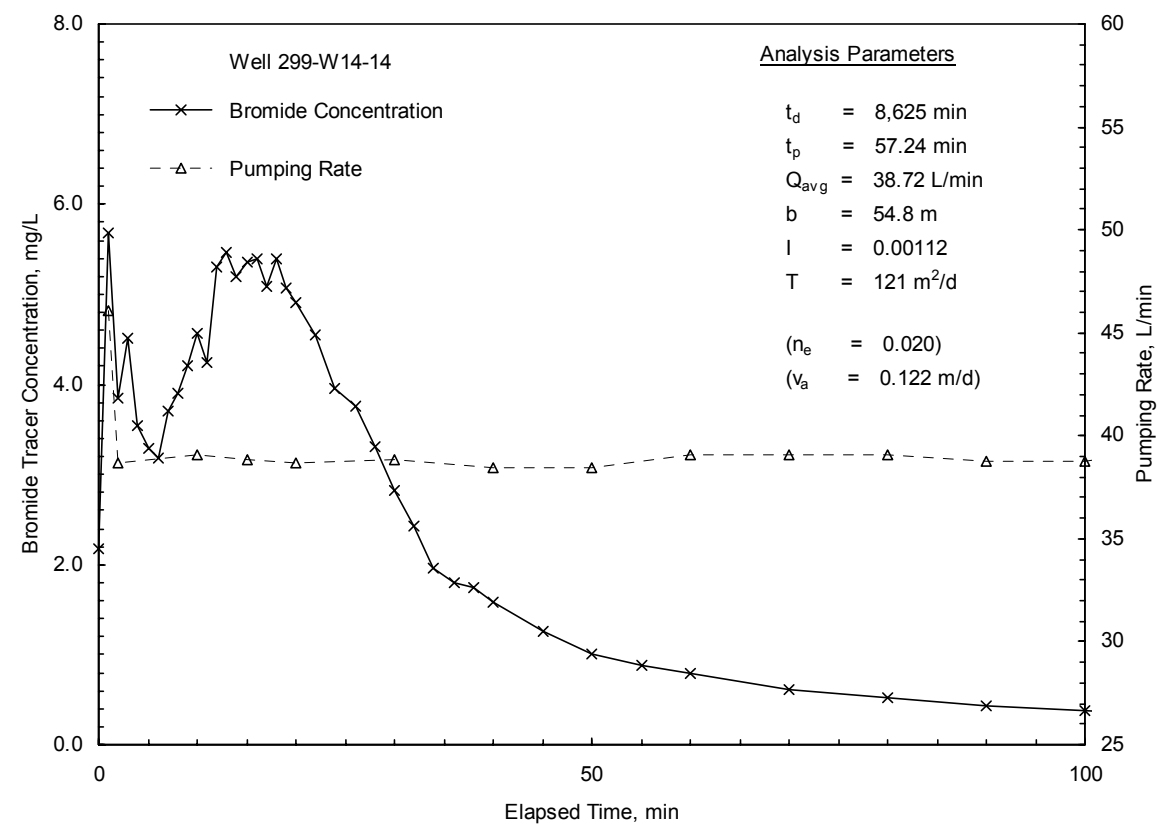

Figure 6.1. Tracer-Pumpback Test Results for Well 299-W14-14

Based on these input parameters and tracer-pumpback results, $\mathrm{n}_{\mathrm{e}}$ and $\mathrm{v}_{\mathrm{a}}$ are estimated to be 0.020 and $0.122 \mathrm{~m} /$ day, respectively. Based on the observed tracer-pumpback profile (see Figure 6.1) and calculated radial distance traveled within the aquifer by the tracer's center of mass (i.e., product of $\mathrm{v}_{\mathrm{a}}$ and $\mathrm{t}_{\mathrm{d}}=$ $0.73 \mathrm{~m}$ ), the results of pumpback reflect local, near-well, aquifer conditions and may be susceptible to the adverse wellbore effects discussed in Section 3.2.2. In addition, because of the vertical flow conditions that were exhibited within the lower section of the well screen during the tracer-dilution test, the estimated values for $\mathrm{n}_{\mathrm{e}}$ and $\mathrm{v}_{\mathrm{a}}$ from the tracer-pumpback test should be considered questionable. This is attributed to the fact that the part of the aquifer within the well-screen section receiving the tracer during dilution/injection may be significantly different than the part of the aquifer providing groundwater during pumpback. Table 6.1 summarizes the pertinent information associated with the tracer-pumpback results for well 299-W14-14. The hydraulic property estimates obtained for the tracer-pumpback results are similar to values reported in Spane et al. (2002) for nearby well 299-W14-15 $\left(\mathrm{n}_{\mathrm{e}}=0.049 ; \mathrm{v}_{\mathrm{a}}=\right.$ $0.114 \mathrm{~m} /$ day $)$. The estimates also fall within, to slightly below the reported range $\left(\mathrm{n}_{\mathrm{e}}=0.1\right.$ to $0.3 ; \mathrm{v}_{\mathrm{a}}=$ 0.003 to $0.59 \mathrm{~m} /$ day) for these parameters in Table A.2 of Hartman et al. (2002) for Waste Management Area TX-TY. It should be noted, however, that the property ranges listed by Hartman et al. (2000) are not based on direct field test results and are either assumed values (i.e., for $\mathrm{n}_{\mathrm{e}}$ ) or calculated, based on the Darcy groundwater-flow equation relationship (i.e., to estimate $\mathrm{v}_{\mathrm{a}}$ ). 
Table 6.1. Tracer-Pumpback Test Summary

\begin{tabular}{|c|c|c|c|c|c|c|c|c|c|}
\hline \multirow[b]{2}{*}{$\begin{array}{c}\text { Waste } \\
\text { Management } \\
\text { Area }\end{array}$} & \multirow[b]{2}{*}{ Well } & \multicolumn{4}{|c|}{ Hydrologic Characterization Data } & \multicolumn{4}{|c|}{ Tracer-Pumpback Test } \\
\hline & & $\begin{array}{c}\text { Aquifer } \\
\text { Thickness, b } \\
(\mathrm{m})\end{array}$ & $\begin{array}{c}\text { Pumping } \\
\text { Rate, Q } \\
\text { (liters/min) }\end{array}$ & $\begin{array}{c}\text { Hydraulic } \\
\text { Gradient, I } \\
(\mathrm{m} / \mathrm{m})\end{array}$ & $\begin{array}{c}\text { Transmissivity, } \mathrm{T} \\
\left(\mathrm{m}^{2} / \text { day }\right)\end{array}$ & $\begin{array}{l}\text { Tracer } \\
\text { Drift } \\
\text { Time, } \mathrm{t}_{\mathrm{d}} \\
(\mathrm{min}) \\
\end{array}$ & $\begin{array}{c}\text { Tracer } \\
\text { Recovery } \\
\text { Time, } \mathrm{t}_{\mathrm{p}} \\
(\mathrm{min}) \\
\end{array}$ & $\begin{array}{c}\text { Effective } \\
\text { Porosity, } \\
\mathrm{n}_{\mathrm{e}}\end{array}$ & $\begin{array}{c}\text { Groundwater- } \\
\text { Flow Velocity, } \\
\text { v }(\mathrm{m} / \text { day })\end{array}$ \\
\hline TX-TY & 299-W14-14 & 54.8 & 38.72 & 0.00112 & 121 & 8,625 & 48.67 & 0.020 & 0.122 \\
\hline$S-S X$ & 299-W22-84 & 68.6 & 27.56 & 0.00183 & 91 & 7,190 & 58.23 & 0.020 & 0.121 \\
\hline $\begin{array}{l}\text { Slight v } \\
\text { questio }\end{array}$ & $\begin{array}{l}\text { cal flow con } \\
\text { le. }\end{array}$ & detec & lower v & reen sec & during tra & ion test & nates $\mathrm{f}$ & and $v_{a} m$ & \\
\hline
\end{tabular}

\subsection{Well 299-W22-84}

After a 7,190 minute (4.99 day) tracer-drift period, $t_{d}$, recovery of the tracer from well 299-W22-84 and the surrounding aquifer was initiated with a constant-rate pumping test beginning on August 19, 2002 (1000 hours PDT). Tracer recovery was terminated after 300 minutes. The average tracer concentration within the well was 0.90 milligrams per liter at the beginning of pumpback, based on late-time projection of the average dilution regression line to the time of tracer pumpback initiation.. Given the calculated well screen and sandpack volumes of 82.1 and 69.4 liters, respectively, 16.24 grams of the 16.43 grams of tracer initially emplaced in the well, are estimated to have been transported within the aquifer. After minor flow adjustments were completed during the first two minutes of the test, pumping rates remained relatively constant during tracer pumpback, ranging between 26.97 and 27.75 liters $/ \mathrm{min}$ (average 27.56 liters/min) for the entire test as shown in Figure 6.2. An estimated 11.88 grams of the total 16.43 grams of tracer (i.e., $72 \%$ ) emplaced in the well were recovered during the constantrate pumping test. The pumping time, $\mathrm{t}_{\mathrm{p}}$, to recover $50 \%$ of the tracer emplaced within the aquifer (accounting for transit time during pumping from the well screen to land surface) is estimated at 58.23 minutes. The time required to recover the center of the tracer mass that was transported within the aquifer was used in Equations 3.8 and 3.9 to calculate $\mathrm{n}_{\mathrm{e}}$ and $\mathrm{v}_{\mathrm{a}}$. As indicated in the equations, information pertaining to hydraulic conductivity, $\mathrm{K}$, hydraulic gradient, I, aquifer thickness, b, and pumping rate, $\mathrm{Q}$, must also be known for the test well site.

A K value of $1.33 \mathrm{~m} /$ day was used, which is based on results from the constant-rate pumping test for the test well (i.e., during tracer pumpback; Section 7.2). The calculated local I value of $0.00183 \mathrm{~m} / \mathrm{m}$ was determined using trend-surface analysis for water-level elevation measurement periods from two nearby monitor wells (299-W22-48 and 299-W23-20) and the test well immediately prior to tracer-dilution testing on August 14, 2002 and prior to tracer pumpback on August 19, 2002 (Section 9.5). The I value is consistent with that listed in Table A.2 of Hartman et al. (2002) $(0.0018$ to $0.0026 \mathrm{~m} / \mathrm{m}$ for Waste Management Area S-SX). The b value of $68.6 \mathrm{~m}$ was calculated directly from projection of known geologic relationships at nearby wells. 


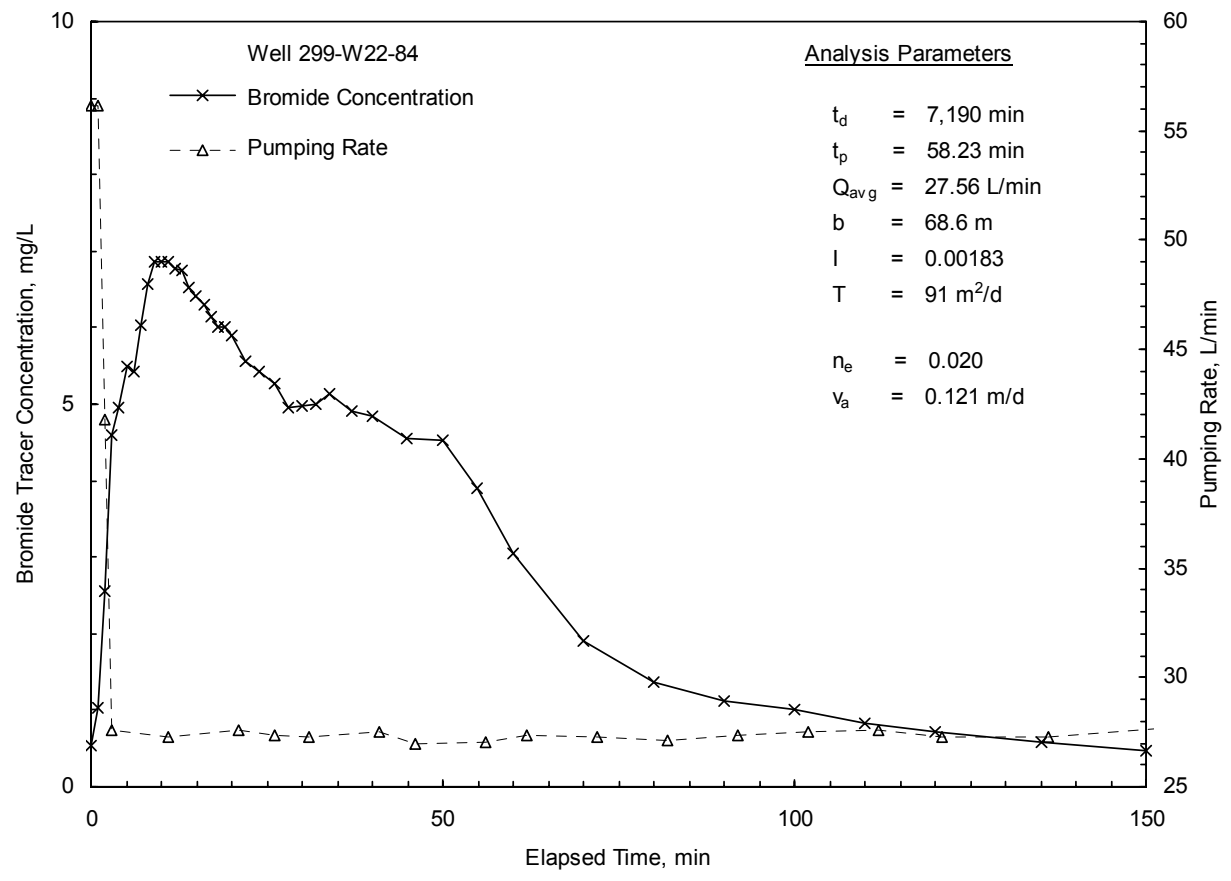

Figure 6.2. Tracer-Pumpback Test Results for Well 299-W22-84

Based on these input parameters and tracer-pumpback results, $\mathrm{n}_{\mathrm{e}}$ and $\mathrm{v}_{\mathrm{a}}$ are estimated to be 0.020 and $0.121 \mathrm{~m} /$ day, respectively. Based on the observed tracer-pumpback profile (see Figure 6.2) and calculated radial distance traveled within the aquifer by the tracer's center of mass (i.e., product of $\mathrm{v}_{\mathrm{a}}$ and $\mathrm{t}_{\mathrm{d}}=$ $0.60 \mathrm{~m}$ ), the results of pumpback reflect local, near-well, aquifer conditions and may be susceptible to the adverse wellbore effects discussed in Section 3.2.2. Table 6.1 summarizes the pertinent information associated with the tracer-pumpback results for well 299-W22-84. The hydraulic property estimates obtained for the tracer-pumpback results are within a factor of two of results reported in Spane et al. (2002) for the nearest Waste Management Area S-SX well characterized previously using single-well tracer tests (well 299-W22-81: $\mathrm{n}_{\mathrm{e}}=0.04 ; \mathrm{v}_{\mathrm{a}}=0.067 \mathrm{~m} /$ day). Other reported results for more distant wells within this area (Spane et al. 2001b, 2002) are reflective of a much higher permeability region (i.e., to the south and southeast of the Waste Management Area S-SX). Comparison of tracer test derived $n_{e}$ and $v_{a}$ estimates for these distinctly different regions, therefore, may not be relevant. 


\subsection{Constant-Rate Pumping Test Results}

Two well sites were selected for detailed hydrologic characterization during FY 2002. At each of these sites, pumping for the tracer-pumpback test was extended and analyzed as a constant-rate pumping test. Analysis of the resulting drawdown and recovery test data at the pumped well provided intermediate-scale estimates for transmissivity $(\mathrm{T})$, hydraulic conductivity $(\mathrm{K})$, vertical anisotropy $\left(\mathrm{K}_{\mathrm{D}}\right)$, storativity $(\mathrm{S})$ and specific yield $\left(\mathrm{S}_{\mathrm{y}}\right)$. Barometric responses at each well were monitored over a baseline period immediately prior to or following termination to tracer-pumpback, when other hydraulic stresses were minimal. These baseline water-level data were analyzed to assess the effects of barometric pressure fluctuations on well water-level responses and remove barometric fluctuations from water levels recorded during the constant-rate pumping test, as discussed in Section 3.3.2. Derivative techniques (see Section 3.3.3) were applied diagnostically to identify aquifer conditions and select the appropriate analysis method. Combined type-curve analysis of both the test responses and the derivative plots was then used to calculate hydraulic properties. The type-curves were generated using the WTAQ3 computer program (Moench 1997) and account for a wide range of test and aquifer conditions including partial penetration, vertical anisotropy, wellbore storage, unconfined aquifer drainage, and well-skin effects. A more detailed description of the various components of the constant-rate pumping-test analysis is provided in Section 3.3.

Descriptions of the performance and analysis of the constant-rate pumping tests are provided below and a summary of results is presented in Table 7.1. K estimates were calculated by dividing $\mathrm{T}$ by the total aquifer thickness, $b$, rather than the length of the well-screen section at the pumping well. This is appropriate because the analysis type curves account for partial penetration of the aquifer and vertical anisotropy. Estimates of $\mathrm{S}$ and $\mathrm{S}_{\mathrm{y}}$ resulting from these two tests are considered less reliable than the estimates of $\mathrm{T}$ and $\mathrm{K}$ because of the lack of analyzable observation well data. Responses at the pumping well are much less sensitive to storage parameters and these parameter estimates are more likely to be affected by near-well heterogeneity.

Table 7.1. Constant-Rate Pumping Test Summary

\begin{tabular}{||c|c|c|c|c|c|c||}
\hline $\begin{array}{c}\text { Pumping } \\
\text { Well }\end{array}$ & Well Analyzed & $\begin{array}{c}\text { Transmissivity, } \\
\mathrm{T}, \mathrm{m}^{2} / \mathrm{day}\end{array}$ & $\begin{array}{c}\text { Horizontal } \\
\text { Hydraulic } \\
\text { Conductivity, } \\
\mathrm{K}_{\mathrm{h}}, \mathrm{m} / \mathrm{day}\end{array}$ & $\begin{array}{c}\text { Vertical } \\
\text { Anisotropy, } \\
\mathrm{K}_{\mathrm{D}}\end{array}$ & $\begin{array}{c}\text { Storativity, } \\
\mathrm{S}\end{array}$ & $\begin{array}{c}\text { Specific } \\
\text { Yield, } \\
\mathrm{S}_{\mathrm{y}}\end{array}$ \\
\hline \hline 299-W14-14 & 299-W14-14 & 121 & 2.21 & 0.005 & 0.0035 & 0.12 \\
\hline 299-W22-84 & 299-W22-84 & 91 & 1.33 & 0.015 & 0.00009 & 0.09 \\
\hline
\end{tabular}




\subsection{Well 299-W14-14}

At the time of testing, the well screen at 299-W14-14 penetrated the upper $9.2 \mathrm{~m}$ of the unconfined aquifer, which has a total estimated thickness of approximately $55 \mathrm{~m}$. The aquifer is within Ringold Unit $\mathrm{E}$ and is composed of fine sand and gravel with some silt. The Ringold lower mud unit forms an aquitard at the bottom of the tested aquifer. An observation well (299-W14-15) located about 50 m away from this well was also monitored during the test. However, because of instrumentation problems, no useable data were obtained from the observation well. The constant-rate discharge test was conducted from 9:00 to 12:30 Pacific standard time on July 18, 2002. Average flow rate during the test was $38.7 \mathrm{~L} /$ minute over the 210-minute pumping period.

Barometric responses were monitored for a 9-day period following recovery at the test well. The multiple-regression deconvolution technique (Rasmussen and Crawford 1997; Spane 1999) was used to remove barometric pressure effects from the water levels measured during the test. A total lag time of 24 hours provided the best match of well water-levels associated with barometric responses during the 9day baseline monitoring period.

Figure 7.1 shows a diagnostic log-log plot of the barometric corrected drawdown and recovery data for pumping well 299-W14-14, and a type-curve match of the recovery data and derivative. The effect of a change in pumping rate is exhibited in the drawdown data during the first 2 minutes of pumping. The drawdown derivative is drastically affected by this change and was, therefore, not plotted. The declining recovery-data derivative pattern shown in Figure 7.1 results primarily from the combination of the decreasing affect of wellbore storage and the increasing influence of partial well-penetration and unconfined aquifer effects. It indicates that there is no portion of the test data where infinite-acting radial flow conditions are established. Therefore, straight-line analysis techniques cannot be used to analyze the test data.

The best type-curve fit of the recovery data is shown in Figure 7.1. This provided the following bestestimate results: $\mathrm{T}=121 \mathrm{~m}^{2} /$ day, $\mathrm{S}=3.5 \mathrm{E}-03$, and $\mathrm{S}_{\mathrm{y}}=0.12$. The $\mathrm{K}$ value of $2.21 \mathrm{~m} /$ day was calculated by dividing $\mathrm{T}$ by the total aquifer thickness, $\mathrm{b}$, because partial penetration is accounted for in the analysis. The type-curve displayed is based on a vertical anisotropy $\left(\mathrm{K}_{\mathrm{D}}\right)$ of 0.005 . This relatively low $\mathrm{K}_{\mathrm{D}}$ value reflects a high degree of vertical anisotropy, and provided a better fit to the test data than higher $\mathrm{K}_{\mathrm{D}}$ values. If a higher value of $K_{D}=0.1$ is chosen for the type-curve match, then a calculated $T$ value of $95 \mathrm{~m}^{2} /$ day results. Figure 7.2 shows the type-curve match for $K_{D}$ of 0.1 . The best estimate $K_{D}$ value of 0.005 , compares favorably with a similarly low $\mathrm{K}_{\mathrm{D}}$ value of 0.0012 , which was also determined at nearby well 299-W14-13 during an earlier constant-rate pumping test (Spane et al. 2001a). 


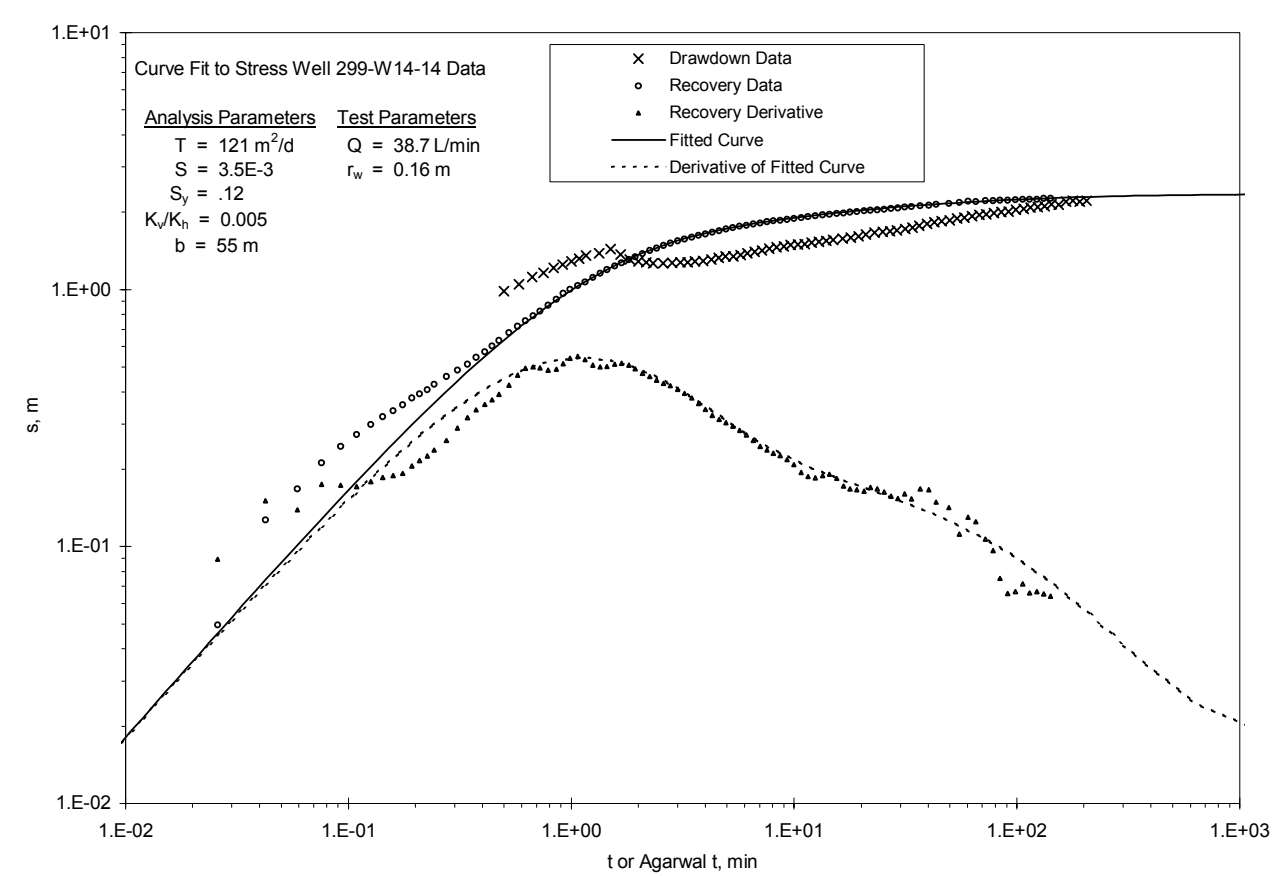

Figure 7.1. Type-Curve and Derivative Plot Analysis of Drawdown and Recovery Test Data for Pumping Well 299-W14-14 Using Best-Fit Parameters

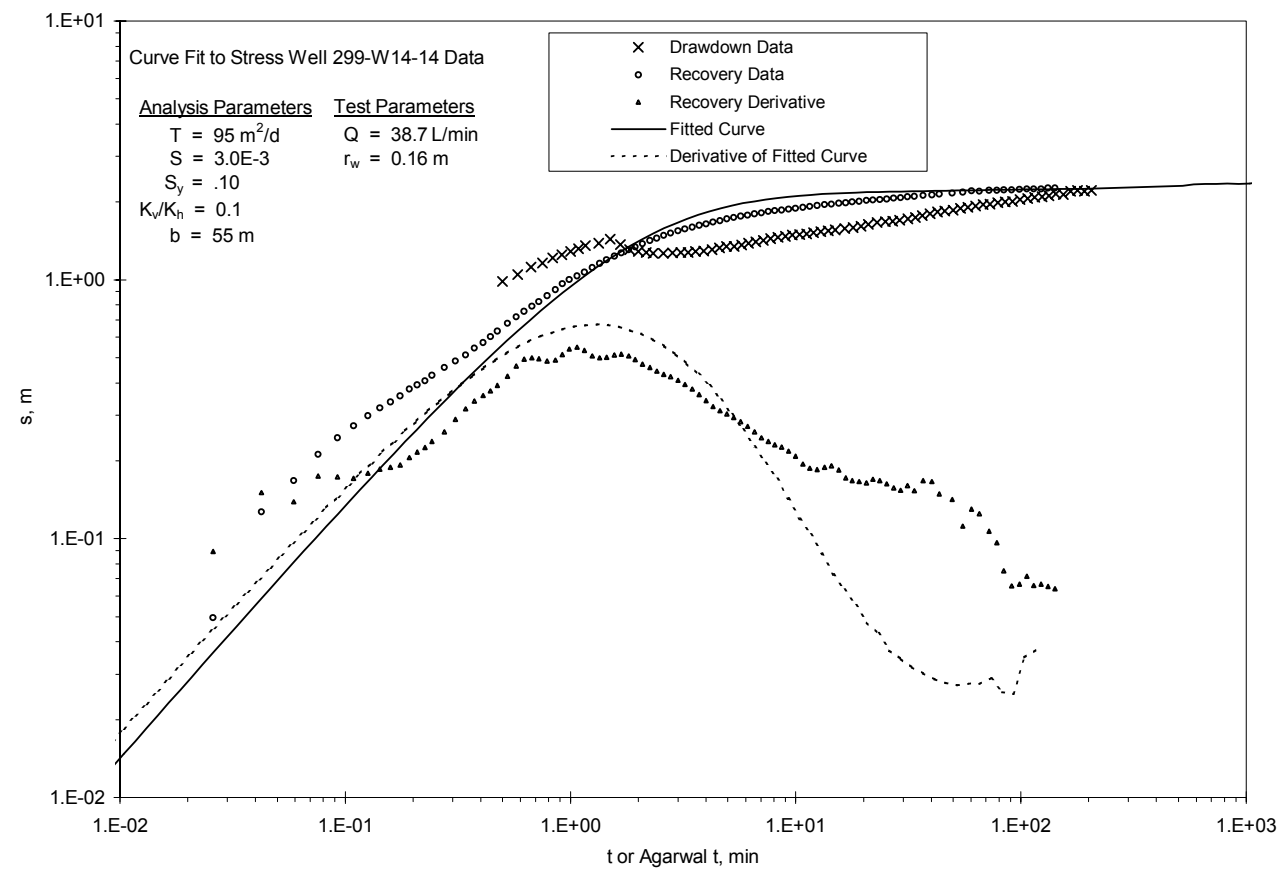

Figure 7.2. Type-Curve and Derivative Plot Analysis of Drawdown and Recovery Test Data for Pumping Well 299-W14-14 Assuming $K_{D}=0.1$ 
As discussed in Section 3.3, the type curve also accounts for partial penetration of the aquifer thickness and well-bore storage. Values of T and K for well 299-W14-14 may be higher than calculated from the type-curve analysis, if significant head losses occurred at the pumping rates used in this test. However, because the pumping rates were relatively low and other new RCRA wells installed in the 200 West Area with similar completion designs have exhibited relatively little head loss at other (similarly constructed) surrounding well sites (Spane et al. 2001a, 2001b), results of the type-curve-fitting analysis for pumping well 299-W14-14 are considered to provide representative estimates of aquifer hydraulic properties.

\subsection{Well 299-W22-84}

At the time of testing, the well screen at well 299-W22-84 penetrated the upper $10.4 \mathrm{~m}$ of the unconfined aquifer. No observation wells were located near enough to this new well to be affected by the aquifer test. The aquifer thickness at the test site is estimated at $68.6 \mathrm{~m}$. The constant-rate discharge test was conducted from 900 to 1400 Pacific Standard Time on August 19, 2002. Average flow rate during the test was $7.04 \mathrm{~L} /$ minute over the 300 -minute pumping period.

Barometric response characteristics were monitored for a 7-d period immediately prior to conducting the test at the well. The multiple-regression deconvolution technique (Rasmussen and Crawford 1997; Spane 1999) was used to remove barometric pressure effects from the water levels measured during the test. A total lag time of $29 \mathrm{hr}$ provided the best match of well water levels associated with barometric responses during the 7-d baseline monitoring period.

Figure 7.3 shows a diagnostic log-log plot of the barometric corrected drawdown and recovery data for pumping well 299-W22-84, and a type-curve match of the recovery data and derivative. The effect of a change in pumping rate is exhibited in the drawdown data after about 2 minutes of pumping. Because the drawdown derivative is drastically affected by this change, it was not useful for type-curve matching and was, therefore, not plotted. The declining recovery-data derivative pattern shown in Figure 7.3 results primarily from the combination of the decreasing affect of wellbore storage and the increasing influence of partial well-penetration and unconfined aquifer effects. It indicates that there is no portion of the test data where infinite-acting radial flow conditions are established. Therefore, straight-line analysis techniques cannot be used to analyze the test data.

The type-curve fit shown in Figure 7.3 provided the following results: $\mathrm{T}=91 \mathrm{~m}^{2} /$ day, $\mathrm{S}=9.0 \mathrm{E}-05$, and $\mathrm{S}_{\mathrm{y}}=0.09$. (Note: $\mathrm{S}$ is assumed, based on the calculated value for $\mathrm{S}_{\mathrm{y}}$ and a fixed $\sigma$ value of 0.001.) The best-estimate $\mathrm{K}$ value of $1.33 \mathrm{~m} /$ day was calculated by dividing $\mathrm{T}$ by the total aquifer thickness, $\mathrm{b}$, because partial penetration is accounted for in the analysis. The type-curve displayed is based on a vertical anisotropy $\left(\mathrm{K}_{\mathrm{D}}\right)$ of 0.015 . This value for $\mathrm{K}_{\mathrm{D}}$ provided the best composite fit for the test data and derivative than higher and lower values of $\mathrm{K}_{\mathrm{D}}$, although the differences in fit were relatively minor. Choosing a $\mathrm{K}_{\mathrm{D}}$ between 0.001 and 0.1 , for example results in a calculated $\mathrm{T}$ value ranging from $120 \mathrm{~m}^{2}$ /day to $63 \mathrm{~m}^{2} /$ day, respectively. As discussed in Section 3.3, the type curve also accounts for partial penetration of the aquifer thickness and wellbore storage. Values of T and K for well 299-W22-84 may be higher than calculated if significant head losses occurred at the pumping rates used in this test. 
However, because the pumping rates were relatively low and other new (similarly constructed) RCRA wells installed in the 200 West Area have exhibited very low head loss characteristics (Spane et al. 2001), results of the type-curve-fitting analysis for pumping well 299-W22-84 are considered to provide representative estimates of aquifer hydraulic properties.

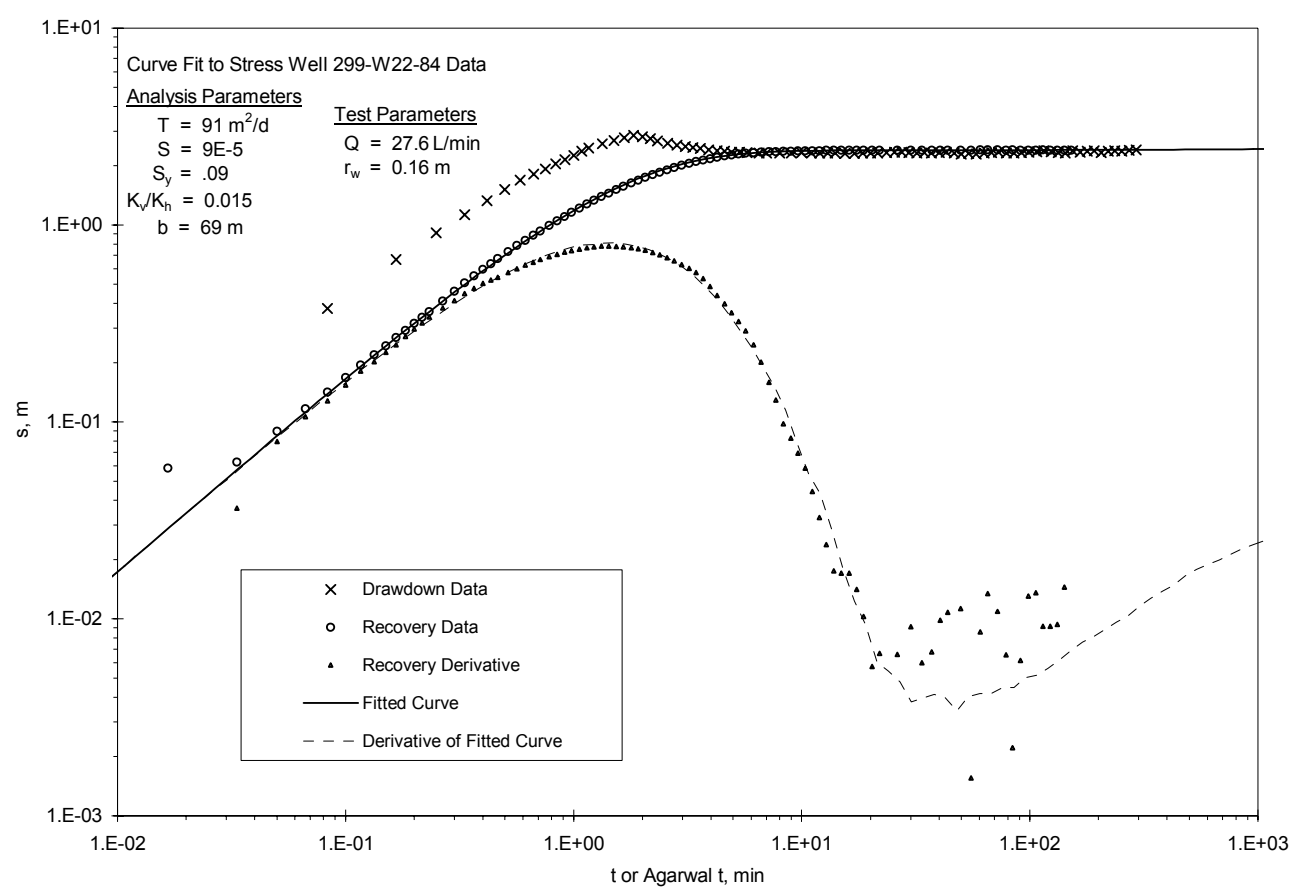

Figure 7.3 Type-Curve and Derivative Plot Analysis of Drawdown and Recovery Test Data for Pumping Well 299-W22-84 


\subsection{In-Well Vertical Flow Assessments}

This chapter discusses the tracer concentration versus depth-response patterns exhibited during the tracer-dilution tests conducted at well 299-W14-14, which exhibited evidence of vertical flow conditions within the lower well-screen section. As discussed in Spane et al. (2001a, 2001b), the cause of the induced, in-well vertical flow conditions is not known, but may be the result of either (1) proximity to local discharge or recharge, (2) heterogeneous formation conditions along the well screen, or (3) effects from neighboring well-pumping/-sampling or remedial action activities. The existence of vertical flow does not necessarily reflect actual groundwater-flow conditions within the surrounding aquifer, but its presence implies a vertical flow gradient and has implications pertaining to the representativeness of groundwater samples collected from such monitor well facilities. Instructive numerical model studies that examine the effects of vertical flow imposed by well-screen completions, in the presence of extremely low hydraulic gradients, are presented in Reilly et al. (1989) and Elci et al. (2001).

In previous site investigations, the presence of in-well vertical flow conditions was quantified using three different test methods: tracer-dilution pattern analysis, vertical flow-tracer tests, and electromagnetic vertical flow-meter surveys. As reported in Spane et al. (2001a, 2001b) close corroboration was exhibited between the three test methods. Because of budgetary constraints, in-well vertical flow conditions indicated by performing tracer-dilution tests were not investigated using either vertical flowtracer tests or electromagnetic surveys for characterization tests conducted during FY 2002. Characterization of in-well vertical flow conditions for the test at well 299-W14-14 conducted during FY 2002 is based only on tracer-dilution pattern assessment, and is summarized in Table 8.1.

Table 8.1. In-Well Vertical Flow Velocity Assessment Based on Tracer-Dilution Pattern Assessment for Well 299-W14-14

\begin{tabular}{|c|c|c|}
\hline \multirow[b]{2}{*}{ Test Well } & \multicolumn{2}{|c|}{ Tracer-Dilution Profile } \\
\hline & $\begin{array}{l}\text { Range, } \\
(\mathrm{m} / \mathrm{min})\end{array}$ & $\begin{array}{l}\text { Average, } \\
(\mathrm{m} / \mathrm{min})\end{array}$ \\
\hline 299-W14-14 & $\begin{array}{c}0.0054-0.0058^{(\mathrm{a})} \\
\downarrow\end{array}$ & $\begin{array}{c}0.0056^{(\mathrm{a})} \\
\downarrow\end{array}$ \\
\hline \multicolumn{3}{|c|}{$\begin{array}{l}\text { Note: Directional symbol }(\downarrow) \text { indicative of vertical flow direction. } \\
\text { (a) As determined using the bottom two probe sensor depths. }\end{array}$} \\
\hline
\end{tabular}

\subsection{Well 299-W14-14}

Visual examination of the tracer concentration versus depth-response patterns shown in Figure 8.1 for the tracer-dilution test conducted on July 12, 2002 (discussed in Section 5.1) indicates a slight, vertical, downward-flow condition within the lower well-screen section; specifically between the bottom two probe depth settings, i.e., between 76.75 to $77.95 \mathrm{~m}$ below brass cap (note: only these two depthresponse patterns are shown for clarity). Downward, in-well flow velocities, ranging between 0.0054 and $0.0058 \mathrm{~m} / \mathrm{min}$, were calculated by using the arrival times of recognizable tracer signatures between these 
two bottom sensors (see Figure 8.1). The presence of downward, in-well flow conditions was also previously exhibited at well 299-W14-13 (as reported in Spane et al. 2001a), which is located 101 m north of the test well. This suggests that the causative factor for the downward, in-well flow conditions may persist over this interwell region of Waste Management Area TX-TY. Table 8.1 summarizes the inwell vertical flow calculations determined within well 299-W14-14.

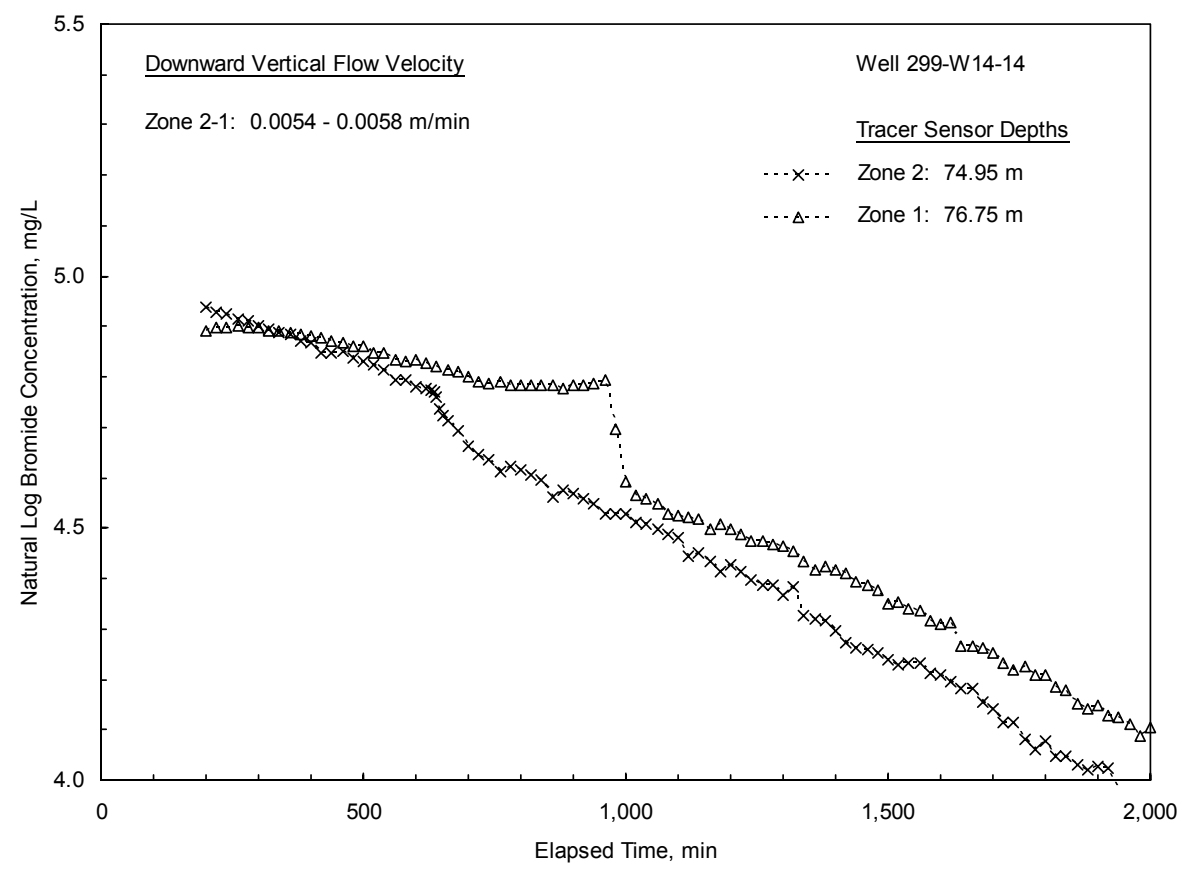

Figure 8.1. Tracer Concentration Versus Depth-Response Patterns Within Well 299-W14-14 During Tracer-Dilution Testing and Calculated In-Well Vertical Flow Velocities 


\subsection{Conclusions}

The detailed hydrologic characterization of the Hanford Site's unconfined aquifer system conducted during FY 2002 included slug tests, single-well tracer tests (i.e., tracer-dilution, tracer-pumpback, and in-well vertical flow assessments), and constant-rate pumping tests. Hydraulic property estimates obtained from the detailed tests include hydraulic conductivity, transmissivity, specific yield, effective porosity, in-well lateral groundwater-flow velocity, aquifer groundwater-flow velocity, vertical distribution of hydraulic conductivity, and in-well vertical flow velocity. In addition, the characteristics of local groundwater flow (i.e., hydraulic gradient, flow direction) were determined for two sites where detailed well testing was performed.

\subsection{Slug-Test and Constant-Rate Pumping Test Results}

Slug-test results provided hydraulic conductivity estimates that ranged between 0.39 and $27.9 \mathrm{~m} /$ day (geometric mean $=3.55 \mathrm{~m} /$ day) for the five 200-West Area wells. Slug test results for the only 200-East Area well tested during FY 2002 provided a hydraulic conductivity estimate of $89.3 \mathrm{~m} /$ day. This high K estimate is consistent with previously reported (Spane et al. 2001a, 2001b) high hydraulic conductivity values for the 200-East Area and are (as noted in Section 2.2) reflective of the preponderance of higher permeability gravel and sand units of either the Hanford formation (Unit 1) or reworked Ringold gravel layer E (Unit 5) of Plio-Pleistocene age.

Estimated values obtained using the Bouwer and Rice analytical method were generally lower and within $30 \%$ of the corresponding estimates obtained using the type-curve method. This is similar to findings of previous studies (e.g., Hyder and Butler 1995; Butler 1998) that evaluated the analytical performance of the Bouwer and Rice method. These findings are also consistent with results reported for Hanford Site tests conducted during FY 1999 through 2001 (Spane et al., 2001a, 2001b, 2002). A wide range in hydraulic conductivity values is listed for the 200-West and 200-East Areas in several earlier reports (e.g., DOE/RL 1993; 200-West Area, 0.02 to $61 \mathrm{~m} /$ day). These results, however, were generally based on slug tests or single-well pumping tests that did not rely on the more exacting analytical methods utilized in this report. In addition, these earlier tests may reflect overlying hydrogeologic units that are no longer saturated, given current site hydrologic conditions (e.g., the water table declined $\sim 6$ meters within the 200-West Area waste management area facilities during the 1990s, due to changes in wastewater disposal activities).

A comparison of the slug-test-derived hydraulic conductivity estimates with the two values obtained from constant-rate pumping tests is shown in Table 9.1. The close correspondence in hydraulic conductivity estimates (i.e., within a factor of two) is consistent with previous, more extensive comparisons between the two test methods (e.g., as noted in Spane et al., 2002). The general comparison relationship exhibited between slug and pumping test estimates also falls within the error range commonly reported for slug tests in aquifer characterization studies (i.e., within a factor of $\sim 2$ or less [e.g., Butler 1996]). 
Table 9.1. Hydraulic Property Summary for Slug- and Constant-Rate Pumping Tests

\begin{tabular}{|c|c|c|c|c|c|}
\hline \multirow[b]{2}{*}{$\begin{array}{c}\text { Waste } \\
\text { Management } \\
\text { Area }\end{array}$} & \multirow[b]{2}{*}{ Well } & \multirow{2}{*}{$\begin{array}{c}\text { Slug Test }^{(\mathrm{a})} \\
\text { Hydraulic } \\
\text { Conductivity, } \mathrm{K}_{\mathrm{h}} \\
\text { (m/day) }\end{array}$} & \multicolumn{3}{|c|}{ Constant-Rate Pumping Test } \\
\hline & & & $\begin{array}{c}\text { Hydraulic } \\
\text { Conductivity, } \mathrm{K}_{\mathrm{h}} \\
\text { (m/day) }\end{array}$ & $\begin{array}{c}\text { Transmissivity, } \mathrm{T} \\
\left(\mathrm{m}^{2} / \text { day }\right)\end{array}$ & $\begin{array}{l}\text { Specific } \\
\text { Yield, } \\
\mathrm{S}_{\mathrm{y}}\end{array}$ \\
\hline \multirow[t]{2}{*}{ S-SX } & 299-W22-84 & $1.15-1.51^{(\mathrm{b})}$ & 1.33 & 91 & 0.09 \\
\hline & 299-W22-85 & $5.69-7.73^{(b)}$ & $-^{(c)}$ & $-(\mathrm{c})$ & $-{ }_{-(\mathrm{c})}$ \\
\hline $\mathrm{T}$ & 299-W10-28 & $27.9^{(\mathrm{d})}$ & - & - & - \\
\hline \multirow[t]{2}{*}{ TX-TY } & 299-W14-14 & $2.31-3.22$ & 2.21 & 121 & 0.12 \\
\hline & 299-W14-18 & $0.39-0.54^{(\mathrm{b})}$ & - & - & - \\
\hline B-BX-BY & 299-E33-338 & $89.3^{(\mathrm{d})}$ & - & - & - \\
\hline \multicolumn{6}{|c|}{$\begin{array}{l}\text { Note: } K_{h}=\text { Assumes aquifer with uniform hydraulic conductivity value. } \\
\text { (a) Unless otherwise indicated, the listed range represents the average } K_{h} \text { value obtained from the Bouwer } \\
\text { and Rice and type-curve analysis methods. } \\
\text { (b) Slug-test response indicated heterogeneous formation conditions; values listed represent outer zone } \\
\text { estimates. } \\
\text { (c) Dashed symbol indicates that a constant-rate pumping test was not conducted at the well site. } \\
\text { (d) Indicates average } K_{h} \text { value obtained from high-permeability (High-K), type-curve analysis method. }\end{array}$} \\
\hline
\end{tabular}

Analysis of the constant-rate pumping test results listed in Table 9.1 indicates that hydraulic property estimates for transmissivity ranged between 91 and $121 \mathrm{~m}^{2}$ per day (average $106 \mathrm{~m}^{2} /$ day). These values fall within the lower range recently reported by Spane et al. (2001a, 2001b, 2002) for constant-rate pumping tests conducted during FY 1999 through 2001 (range $=44$ to $1130 \mathrm{~m}^{2} /$ day; average = $334 \mathrm{~m}^{2}$ /day) within the 200-West Area. The two FY 2002 pumping test-derived values are also lower than the large-scale transmissivity values of 300 and $327 \mathrm{~m}^{2} /$ day that were reported in Newcomb and Strand (1953) and Wurstner et al. (1995), respectively, for the unconfined aquifer within the 200-West Area. These previously reported values were based on analyzing the areal growth and decline of the groundwater mound that developed in this area as a result of wastewater disposal. The FY 2002 pumping test values also are lower than the large-scale analysis of induced areal composite pumping/injection effects of the 200-ZP-1 pump-and-treat system reported in Spane and Thorne (2000), which produced large-scale estimates that range between 230 and $430 \mathrm{~m}^{2} /$ day (average $325 \mathrm{~m}^{2} /$ day).

Results of pumping tests also correspond fairly closely for specific yield, ranging between 0.09 and 0.12, and fall within the range previously reported in Spane et al. (2001a, 2001b, 2002) for pumping tests within this area. These results also compare favorably with previously reported estimates of 0.11 and 0.17 for the 200-West Area (i.e., Newcomb and Strand 1953; Wurstner et al. 1995). These earlier estimates were based on analyzing the growth and decline of the groundwater mound beneath the 200-West Area associated with wastewater-disposal practices in the area. However, the specific yield estimates derived from the pumping tests are qualitative. This is due to the relatively short-durations (i.e., $\sim 4$ to 6 hours), and other limitations discussed in Section 3.3. 


\subsection{Tracer-Dilution Test Results}

Table 9.2 lists the tracer-dilution results for the two wells tested. As discussed in Chapter 5, well 299-W14-14 exhibited in-well vertical flow conditions within the lower well-screen section that may compromise the overall results of this characterization test for this well site. Average, in-well lateral flow velocities, $\mathrm{v}_{\mathrm{w}}$, for the two sites ranged between 0.041 to $0.090 \mathrm{~m} /$ day. (Note: As shown in Equation 3.5 and discussed in Section 3.2.1, in-well flow velocity is related, but not equivalent, to actual groundwaterflow velocity within the aquifer.) These $\mathrm{v}_{\mathrm{w}}$ estimates are within the range of 0.007 and $0.170 \mathrm{~m} /$ day cited in Spane et al. (2001a, 2001b, 2002).

A comparison of the observed depth versus velocity profiles provided information about permeability distribution within the well-screen sections at the two well sites. At well 299-W14-14, very uniform low, in-well lateral flow velocities were exhibited for the upper three sensor depth locations (range: 0.037 to $0.040 \mathrm{~m} /$ day). This suggests that formation permeabilities do not vary by more than $10 \%$ within the upper $\sim 5$ meter section of the well screen.

For well 299-W22-84 slightly more variable in-well lateral flow velocities were exhibited (range: 0.076 to $0.094 \mathrm{~m} /$ day), suggesting that permeabilities do not vary by more than $20 \%$ within the entire well-screen section; with the lowest relative permeabilities (i.e., lower flow velocities) occurring within the upper section of the well-screen.

Table 9.2. Tracer-Dilution Test Summary

\begin{tabular}{|c|c|c|c|c|c|c|c|}
\hline Well & $\begin{array}{c}\text { Test Interval, } \\
\text { m, below } \\
\text { brass cap }^{(a)}\end{array}$ & $\begin{array}{l}\text { Date Test } \\
\text { Initiated }\end{array}$ & $\begin{array}{l}\text { Total Dilution } \\
\text { Time, } t_{d}(\mathrm{~min}) \\
\end{array}$ & $\begin{array}{c}\text { Average Initial } \\
\text { Tracer } \\
\text { Concentration, } \\
\mathrm{C}_{\mathrm{o}}{ }^{(\mathrm{b})}(\mathrm{mg} / \text { liter })\end{array}$ & $\begin{array}{l}\text { Average Final } \\
\text { Tracer } \\
\text { Concentration, } \\
\mathrm{C}_{\mathrm{t}}^{(\mathrm{c})}(\mathrm{mg} / \text { liter })\end{array}$ & $\begin{array}{c}\text { Average Flow } \\
\text { Velocity, } \\
\mathrm{v}_{\mathrm{w}}{ }^{(\mathrm{d})}(\mathrm{m} / \text { day }) \\
\end{array}$ & $\begin{array}{c}\text { Range Flow } \\
\text { Velocity, } \\
\mathrm{v}_{\mathrm{wz}}{ }^{(\mathrm{e})}(\mathrm{m} / \text { day }) \\
\end{array}$ \\
\hline 299-W14-14 & $67.99-76.81$ & $7 / 12 / 02$ & 8,625 & 173 & 3.72 & $\begin{array}{c}v f^{(f)} \\
(0.041)\end{array}$ & $0.037-0.040^{(\mathrm{g})}$ \\
\hline 299-W22-84 & $71.16-81.38$ & $8 / 14 / 02$ & 7,190 & 196 & 0.90 & 0.090 & $0.076-0.094^{(\mathrm{h})}$ \\
\hline \multicolumn{8}{|c|}{ (a) Below brass cap datum. } \\
\hline \multicolumn{8}{|c|}{ (b) Estimated initial tracer concentration based on early-time, linear back-projection of average well-screen conditions. } \\
\hline \multicolumn{8}{|c|}{ (c) Estimated tracer concentration at termination of test based on late-time, linear projection of average well-screen conditions. } \\
\hline \multicolumn{8}{|c|}{ (d) Determined from regression analysis of average, composite well-screen dilution pattern. } \\
\hline \multicolumn{8}{|c|}{ (e) Groundwater flow-velocity range within well determined from individual sensor-depth s } \\
\hline \multicolumn{8}{|l|}{ (f) } \\
\hline \multicolumn{8}{|l|}{$(\mathrm{g})$} \\
\hline \multicolumn{8}{|l|}{ (h) } \\
\hline
\end{tabular}




\subsection{Tracer-Pumpback Test Results}

Table 6.1 lists information pertaining to the two tracer-pumpback tests performed. Only well 299W14-14 exhibited slight vertical-flow conditions within part of the well-screen section during the tracerdilution test. The fact that the tracer entered the aquifer within a small portion of the well screen may seriously impact the assumptions of the test. The tracer-pumpback results for this well (which is affected by vertical flow conditions) may make the results of this test questionable and, therefore, should not be used for quantitative assessment. The estimates calculated from the tests, however, are provided in the table for comparison/informational purposes only.

Estimates for effective porosity for the two test sites (wells 299-W14-14 and 299-W22-84) were identical at 0.020 . This value falls slightly below, the range commonly reported for semi-consolidated to unconsolidated alluvial aquifers $(0.05$ to 0.30$)$ and falls within the lower range previously reported for $n_{e}$ by Spane et al. (2001a, 2001b, 2002) of 0.027 and 0.272 for single-well tracer tests conducted in the 200West Area.

Estimates for aquifer groundwater-flow velocity also were nearly identical and ranged between 0.121 and $0.122 \mathrm{~m} /$ day and generally fall within a factor of 3 of the calculated, in-well flow velocities. A similar relationship between groundwater-flow velocity estimates and calculated in-well flow velocities was reported in Spane et al. (2001a, 2001b, 2002) for single-well tracer tests conducted during FY 1999 through FY 2001.

\subsection{In-Well Vertical Flow Test Results}

As noted previously, the tracer concentration versus depth-response patterns exhibited during the tracer-dilution test conducted in well 299-W14-14 exhibited evidence of vertical flow conditions within the lower part of the well-screen section. The cause of the induced flow conditions is not known but may be the result of either (1) proximity to local recharge areas, (2) heterogeneous formation conditions along the well screen, or (3) temporal effects from neighboring well-pumping/-sampling activities. The existence of in-well vertical flow is not necessarily reflective of actual groundwater-flow conditions within the surrounding aquifer, but its presence has implications pertaining to the representativeness of groundwater samples collected from such monitor well facilities (i.e., water samples collected from the well may not be reflective of aquifer materials within the entire well-screen section).

As during FY 2001, the results of in-well vertical flow conditions for tests conducted during FY 2002 are based only on tracer-dilution pattern assessment. These results are summarized in Table 8.1. The average in-well vertical downward flow rate ranged from 0.0054 to $0.0058 \mathrm{~m} / \mathrm{minute}$. These calculated in-well vertical flow rates fall within the range reported for $v_{v}$ by Spane et al. (2001a, 2001b, 2002) of 0.001 and $0.032 \mathrm{~m} /$ minute for single-well tracer tests conducted in the 200-West Area (i.e., using the tracer-dilution assessment method). In addition, the corroboration of the vertically downward, in-well flow condition at well 299-W14-14 at a neighboring well suggests that the causative factor for the vertical in-well flow conditions may persist over interwell distances of up to $\sim 100$ meters at some locations. 


\subsection{Groundwater-Flow Characterization Results}

Table 9.3 lists results pertaining to the determination of groundwater-flow direction and hydraulic gradient conditions at the various sites during the period of tracer testing. Groundwater-flow direction and hydraulic gradient were calculated using the commercially available WATER-VEL (In-Situ, Inc. 1991) software program. Water-level elevations from neighboring, representative wells were used as input to the WATER-VEL program to calculate groundwater-flow direction and hydraulic gradient conditions during the detailed characterization period. The program uses a linear, two-dimensional trend surface (least squares) to randomly located hydrologic head or water-level elevation input data. This method is similar also to the linear approximation technique described by Abriola and Pinder (1982) and Kelly and Bogardi (1989). Reports that demonstrate the use of the WATER-VEL program for calculation of groundwater-flow velocity and direction on the Hanford Site include Gilmore et al. (1992), Spane (1999), and Spane et al. (2001a, 2001b, 2002).

The hydraulic gradient calculations listed in Table 9.3 were used to calculate the estimates of effective porosity and groundwater-flow velocity shown in Table 6.1. The indicated easterly and southeasterly groundwater-flow directions are consistent with generalizations presented in Hartman et al. (2002) for these wells.

Table 9.3. Groundwater-Flow Characterization Results Based on Trend-Surface Analysis

\begin{tabular}{|c|c|c|c|c|}
\hline Well & $\begin{array}{c}\text { Measurement } \\
\text { Date }\end{array}$ & $\begin{array}{l}\text { Groundwater-Flow } \\
\text { Direction }^{\text {(a) }}\end{array}$ & $\begin{array}{c}\text { Hydraulic } \\
\text { Gradient }(\mathrm{m} / \mathrm{m}) \\
\end{array}$ & Wells Used in Analysis \\
\hline \multirow{3}{*}{ 299-W14-14 } & $7 / 12 / 02$ & $318^{\circ}$ & 0.00114 & 299-W14-13 \\
\hline & \multirow{2}{*}{$7 / 22 / 02$} & \multirow{2}{*}{$317^{\circ}$} & \multirow{2}{*}{0.00109} & 299-W14-16 \\
\hline & & & & 299-W14-17 \\
\hline \multirow{3}{*}{ 299-W22-84 } & \multirow[t]{2}{*}{$8 / 14 / 02$} & \multirow[t]{2}{*}{$335^{\circ}$} & \multirow[t]{2}{*}{0.00183} & 299-W22-48 \\
\hline & & & & 299-W22-84 \\
\hline & $8 / 19 / 02$ & $336^{\circ}$ & 0.00182 & 299-W23-20 \\
\hline
\end{tabular}




\subsection{References}

Abriola LM and GF Pinder. 1982. "Calculation of velocity in three space dimensions from hydraulic head measurements.” Ground Water 20(2):205-213.

Agarwal RG. 1980. "A new method to account for producing time effects when drawdown type curves are used to analyze pressure buildup and other test data." SPE Paper 9289, Society of Petroleum Engineers, Dallas, Texas.

Bourdet DJ, A Ayoub, and YM Pirard. 1989. "Use of pressure derivative in well-test interpretation." SPE Formation Evaluation June 1989:293-302.

Bouwer H. 1989. “The Bouwer and Rice slug test - an update.” Ground Water 27(3):304-309.

Bouwer H. 1996. "Discussion of Bouwer and Rice slug test review articles.” Ground Water 34(1):171.

Bouwer H and RC Rice. 1976. "A slug test for determining hydraulic conductivity of unconfined aquifers with completely or partially penetrating wells." Water Resources Research 12(3):423-428.

Brown DL, TN Narasimhan, and Z Demir. 1995. "An evaluation of the Bouwer and Rice method of slug test analysis." Water Resources Research 31(5):1239-1246.

Butler JJ, Jr. 1990. "The role of pumping tests in site characterization: some theoretical considerations." Ground Water 28(3):394-402.

Butler JJ, Jr. 1996. "Slug tests in site characterization: some practical considerations." Environmental Geosciences 3(3):154-163.

Butler JJ, Jr. 1998. The design, performance, and analysis of slug tests. Lewis Publishers, CRC Press, Boca Raton, Florida. .

Butler, JJ, Jr. and EJ Garnett. 2000. Simple procedures for analysis of slug tests in formations of high hydraulic conductivity using spreadsheet and Scientific Graphics Software. Open-file Report 2000-40, Kansas Geological Survey, Lawrence, Kansas.

Butler, JJ, Jr., GC Bohling, ZH Hyder, and CD McElwee. 1994. "The use of slug tests to describe vertical variations in hydraulic conductivity.” Journal of Hydrology 156:137-162

Butler JJ, CD McElwee, and W Liu. 1996. "Improving the quality of parameter estimates obtained from slug tests." Ground Water 34(3):480-490.

Connelly MP, JV Borghese, CD Delaney, BH Ford, JW Lindberg, and SJ Trent. 1992a. Hydrogeologic model for the 200-East groundwater aggregate area. WHC-SD-EN-TI-019, Rev. 0, Westinghouse Hanford Company, Richland, Washington. 
Connelly MP, BH Ford, and JV Borghese. 1992b. Hydrogeologic model for the 200-West groundwater aggregate area. WHC-SD-EN-TI-014, Rev. 0, Westinghouse Hanford Company, Richland, Washington.

Cooper HH, Jr. and CE Jacob. 1946. "A generalized graphical method for evaluating formation constants and summarizing well-field history." American Geophysical Union, Transactions 27(4):526-534.

DOE/RL. 1993. 200 West groundwater aggregate area management study report. DOE/RL-92-16, Rev. 0, U.S. Department of Energy, Richland Operations Office, Richland, Washington.

Drost W, D Klotz, A Koch, H Moser, F Neumaier, and W Rauert. 1968. "Point dilution methods of investigating groundwater flow by means of radioisotopes." Water Resources Research 4(1):125-146.

Elci A, FJ Molz III, and WR Waldrop. 2001. "Implications of observed and simulated ambient flow in monitoring wells." Ground Water 39(6):853-862.

Freeze RA and JA Cherry. 1979. Groundwater. Prentice-Hall, Englewood Cliffs, New Jersey.

Gephart RE, FA Spane, LS Leonhart, DA Palombo, and SR Strait. 1979. "Pasco Basin hydrology." In Hydrologic studies within the Columbia plateau, Washington: An integration of current knowledge, pp. III-1 to III-236. RHO-BWI-ST-5, Rockwell Hanford Operations, Richland, Washington.

Gilmore TJ, DR Newcomer, SK Wurstner, and FA Spane, Jr. 1992. Calculation of groundwater discharge to the Columbia River in the 100-N area. PNL-8057, Pacific Northwest Laboratory, Richland, Washington.

Graham MJ, GV Last, and KR Fecht. 1984. An assessment of aquifer intercommunication in the B-Pond-Gable Mountain Pond area of the Hanford site. RHO-RE-ST-12P, Rockwell Hanford Operations, Richland, Washington.

Güven O, RW Falta, FJ Molz, and JG Melville. 1985. "Analysis interpretation of single-well tracer tests in stratified aquifers." Water Resources Research 21(5):676-684.

Guyonnet D, S Mishra, and J McCord. 1993. "Evaluating the volume of porous medium investigated during slug tests." Ground Water 31(4):627-633.

Halevy E, H Moser, O Zellhofer, and A Zuber. 1966. "Borehole dilution techniques - a critical review." In Isotopes in Hydrology, International Atomic Energy Agency, Vienna, Austria.

Hall SH. 1993. "Single well tracer tests in aquifer characterization." Ground Water Monitoring \& Review 13(2):118-124.

Hall SH, SP Luttrell, and WE Cronin. 1991. "A method for estimating effective porosity and groundwater velocity." Ground Water 29(2):171-174. 
Hantush MS. 1964. "Hydraulics of wells." Advances in Hydroscience (VT Chow, ed) 1:282-433, Academic Press, New York.

Hartman MJ, LF Morasch, and WD Webber, (eds). 2002. Hanford Site groundwater monitoring for fiscal year 2001. PNNL-13788, Pacific Northwest National Laboratory, Richland, Washington.

Hyder Z and JJ. Butler, Jr. 1995. "Slug tests in unconfined formations: An assessment of the Bouwer and Rice technique." Ground Water 33(1):16-22.

In-Situ Inc. 1991. WATER-VEL ${ }^{T M}$ groundwater velocity. ISI-GWV-2.21-1, Laramie, Wyoming.

Karasaki K, JCS Long, and PA Witherspoon. 1988. “Analytical Models of Slug Tests.” Water Resources Research 24(1):115-126.

Kearl PM, JJ Dexter, and JE Price. 1988. Procedures, analysis, and comparison of groundwater velocity measurement methods for unconfined aquifers. UNC/GJ-TMC-3, UNC Geotech, Grand Junction, Colorado.

Kelly WE and I Bogardi. 1989. "Flow directions with a spreadsheet." Ground Water-Computer Notes 27(2):245-247.

Leap DI and PG Kaplan. 1988. "A single-well tracing method for estimating regional advective velocity in a confined aquifer: Theory and preliminary laboratory verification." Water Resources Research 24(7):993-998.

Lindsey KA. 1995. Miocene- to Pliocene-aged suprabasalt sediments of the Hanford Site, south-central Washington. BHI-00184, Bechtel Hanford Inc., Richland, Washington.

Lindsey KA, BN Bjornstad, JW Lindberg, and KM Hoffman. 1992. Geologic setting of the 200-East area: An update. WHC-SD-EN-TI-012, Rev. 0, Westinghouse Hanford Company, Richland, Washington.

Liu WZ and JJ Butler, Jr. 1995. The KGS model for slug tests in partially penetrating wells (Version 3.0). Kansas Geological Survey Computer Series Report 95-1, Lawrence, Kansas.

McElwee CD and MA Zenner. 1998. "A nonlinear model for analysis of slug-test data." Water Resources Research 34(1):55-66.

Moench AF. 1997. "Flow to a well of finite diameter in a homogeneous, anisotropic water-table aquifer." Water Resources Research 33(6):1397-1407.

Moench AF and PA Hsieh. 1985. "Analysis of slug test data in a well with finite-thickness skin." In Memoirs Hydrogeology of Rocks of Low Permeability, January 7-12, 1985, Tucson, Arizona; International Association of Hydrogeologists 17(1):17-29. 
Molz FJ, JG Melville, O Güven, RD Crocker, and KT Matteson. 1985. "Design and performance of single-well tracer tests at the Mobile site." Water Resources Research 21(10):1497-1502.

Neuman SP. 1972. "Theory of flow in unconfined aquifers considering delayed response of the water table." Water Resources Research 8(4):1031-1045.

Neuman SP. 1974. "Effect of partial penetration of flow in unconfined aquifer considering delayed gravity response.” Water Resources Research 10(2):303-312.

Neuman SP. 1975. "Analysis of pumping test data from anisotropic unconfined aquifers considering delayed gravity response." Water Resources Research 11(2):329-342.

Newcomb RC and JR Strand. 1953. Geology and ground-water characteristics of the Hanford Reservation of the U.S. Atomic Energy Commission, Washington. Administrative Report WP-8, U.S. Geological Survey, Washington, D.C.

Novakowski KS. 1989. "Analysis of pulse interference tests." Water Resources Research 25(11):2377-2387.

Pickens JF, and GE Grisak. 1981. "Scale-dependent dispersion in a stratified granular aquifer." Water Resources Research 17(4):1191-1211.

Rasmussen TC and LA Crawford. 1997. "Identifying and removing barometric pressure effects in confined and unconfined aquifers." Ground Water 35(3):502-511.

Reilly TE, OL Franke, and GD Bennett. 1989. "Bias in groundwater samples caused by wellbore flow." Journal of Hydraulic Engineering 115(2):270-276.

Resource Conservation and Recovery Act of 1976, as amended, Public Law 94-580, 90 Stat. 2795, 42 USC 6901 et seq.

Spane FA, Jr. 1993. Selected hydraulic test analysis techniques for constant-rate discharge tests. PNL-8539, Pacific Northwest Laboratory, Richland, Washington.

Spane FA, Jr. 1996. "Applicability of slug interference tests for hydraulic characterization of unconfined aquifer: (1) Analytical assessment." Ground Water 34(1):66-74.

Spane FA, Jr. 1999. Effects of barometric fluctuations on well water-level measurements and aquifer test data. PNNL-13078, Pacific Northwest National Laboratory, Richland, Washington.

Spane FA, Jr. 2002. "Considering barometric pressure in groundwater flow investigations." Water Resources Research 38(6), 14:1-18.

Spane FA, Jr. and SK Wurstner. 1993. "DERIV: A program for calculating pressure derivatives for use in hydraulic test analysis." Ground Water 31(5):814-822. 
Spane FA, Jr. and WD Webber. 1995. Hydrochemistry and hydrogeologic conditions within the Hanford Site upper basalt confined aquifer system. PNL-10817, Pacific Northwest Laboratory, Richland, Washington.

Spane FA, Jr. and PD Thorne. 2000. Analysis of the hydrologic response associated with shutdown and restart of the 200-ZP-1 pump-and-treat system. PNNL-13342, Pacific Northwest National Laboratory, Richland, Washington.

Spane FA, Jr., PD Thorne, and LC Swanson. 1996. “Applicability of slug interference tests for hydraulic characterization of unconfined aquifer: (2) Field test examples." Ground Water 34(5):925-933.

Spane FA, Jr., PD Thorne, and DR Newcomer. 2001a. Results of detailed hydrologic characterization tests - fiscal year 1999. PNNL-13378, Pacific Northwest National Laboratory, Richland, Washington.

Spane FA, Jr., PD Thorne, and DR Newcomer. 2001b. Results of detailed hydrologic characterization tests - fiscal year 2000. PNNL-13514, Pacific Northwest National Laboratory, Richland, Washington.

Spane FA, Jr., PD Thorne, and DR Newcomer. 2002. Results of detailed hydrologic characterization tests - fiscal year 2001. PNNL-14113, Pacific Northwest National Laboratory, Richland, Washington.

Springer RK and LW Gelhar. 1991. "Characterization of large-scale aquifer heterogeneity in glacial outwash by analysis of slug tests with oscillatory response, Cape Cod, Massachusetts." In U.S. Geological Survey Water Resources Investigations. Report 91-4034:36-40.

Theis CV. 1935. "The relationship between the lowering of the piezometric surface and the rate and duration of discharge of a well using ground-water storage." American Geophysical Union, Transactions, 2:519-524; reprinted in Society of Petroleum Engineers, "Pressure Transient Testing Methods", SPE Reprint Series (14):27-32, Dallas, Texas.

Thorne PD, MA Chamness, FA Spane, Jr., VR Vermeul, and WD Webber. 1993. Three-dimensional conceptual model for the Hanford Site unconfined aquifer system, FY 93 status report. PNL-8971, Pacific Northwest Laboratory, Richland, Washington.

Weeks EP. 1979. "Barometric fluctuations in wells tapping deep unconfined aquifers." Water Resources Research 15(5):1167-1176.

Williams BA, BN Bjornstad, R Schalla, and WD Webber. 2000. Revised hydrogeology for the suprabasalt aquifer system, 200-East area and vicinity, Hanford Site, Washington. PNNL-12261, Pacific Northwest National Laboratory, Richland, Washington.

Wurstner SK, PD Thorne, MA Chamness, MD Freshley, and MD Williams. 1995. Development of a three-dimensional ground-water model of the Hanford Site unconfined aquifer system: FY 1995 status report. PNL-10886, Pacific Northwest Laboratory, Richland, Washington.

Zurbuchen BR, VA Zlotnik, and JJ Butler, Jr. 2002. "Dynamic interpretation of slug tests in highly permeable aquifers.” Water Resources Research 38(3), 7:1-18. 


\section{Distribution}

No. of

Copies

\section{OFFSITE}

Confederated Tribes of the Umatilla Indian Reservation

P.O. Box 638

Pendleton, OR 97801

ATTN: S. Harris

B. W. Drost

Geological Survey

U.S. Department of the Interior

1201 Pacific Avenue, Suite 600

Tacoma, WA 98402

W. N. Herkelrath

Geological Survey

U.S. Department of the Interior

345 Middlefield Road, MS 496

Menlo Park, CA 94025

Idaho National Engineering and

Environmental Laboratory

Lockheed Martin Idaho Technology Co.

P.O. Box 1625

Idaho Falls, ID 83415-2107

ATTN: J. B. Sisson

Nez Perce Tribe

Environmental Restoration/Waste Management

P.O. Box 365

Lapwai, ID 83540-0365

ATTN: P. Sobotta

2 T. Kirk

Washington State

Department of Ecology

Water Resources Program

Central Regional Office

15 W. Yakima Avenue, Suite 200

Yakima, WA 98902-3401
No. of

Copies

Washington State

Department of Health

Division of Radiation Protection

P.O. Box 47827

Olympia, WA 98504-7827

ATTN: D. McBaugh

Wanapum People

Grant County P.U.D.

P.O. Box 878

Ephrata, WA 98823

ATTN: L. Seelatsee

Yakama Indian Nation

Environmental Restoration/Waste

Management Program

2802 Main Street

Union Gap, WA 98903

ATTN: W. Rigsby

ONSITE

DOE Office of River Protection

R. M. Yasek

H6-60

7 DOE Richland Operations Office

M. J. Furman

$\mathrm{H} 0-12$

R. D. Hildebrand

$\mathrm{H} 0-12$

J. G. Morse

$\mathrm{H} 0-12$

K. M. Thompson

$\mathrm{H} 0-12$

A. C. Tortoso

$\mathrm{H} 0-12$

Public Reading Room (2)

$\mathrm{H} 2-53$

2 CH2M HILL Hanford Group, Inc.

A. J. Knepp

E6-35

D. J. Meyer

E6-35

Distr.1 
No. of

Copies

2 Duratek Federal Services, Inc.

M. G. Gardner

H1-11

S. H. Worley

H1-11

3 Fluor Hanford, Inc.
R. L. Jackson
H0-19
J. V. Borghese
H0-21
L. C. Swanson
H9-02

\section{U.S. Environmental Protection Agency}

D. A. Faulk

B5-01

2 Washington State Department of

Ecology

J. Caggiano

B5-18

D. Goswami

B5-18

\section{Pacific Northwest National Laboratory}

D. B. Barnett

K6-81

M. P. Bergeron
No. of

Copies

P. E. Dresel K6-96

M. J. Fayer K9-33

M. D. Freshley K9-36

J. S. Fruchter K6-96

T. J Gilmore K6-81

M. J. Hartman K6-96

V. G. Johnson K6-96

C. T. Kincaid K9-33

G. V. Last K6-81

J. W. Lindberg K6-81

S. P. Luttrell K6-96

J. P. McDonald K6-96

S. M. Narbutovskih K6-96

D. R. Newcomer K6-96

R. E. Peterson K6-96

J. T. Rieger K6-96

R. M. Smith K6-96

F. A. Spane, Jr. (3) K6-96

D. L. Stewart K6-96

M. D. Sweeney K6-81

P. D. Thorne K9-33

E. C. Thornton K6-96

W. D. Webber K6-96

B. A. Williams K6-81

S. K. Wurstner K9-36

Hanford Technical Library (2) P8-55 